\title{
Culture Unbound:
}

Journal of Current Cultural Research

\section{Thematic Section:}

Reports and Reflections from the Field:

Current Issues in European Cultural Studies

Edited by

Ferda Keskin

Extraction from Volume 5, 2013

Linköping University Electronic Press

Culture Unbound: ISSN 2000-1525 (online)

URL: http://www.cultureunbound.ep.liu.se/

(C) 2013 The Authors. 
Culture Unbound, Extraction from Volume 5, 2013

\section{Thematic Section: Reports and Reflections from the Field: Current Issues in European Cultural Studies}

\section{Ferda Keskin}

European Cultural Studies: Pathways in an Unbound Geography

\section{Mica Nava}

Cultural Studies, History and Cosmopolitanism in UK

\section{Udo Göttlich}

Cultural Studies and Sociology of Culture in Germany: Relations and Interrelations 33

\section{Gönül Pultar}

Cultural Studies in Turkey: The State of the Art.... 43

\section{Sofia Sampaio}

Portuguese Cultural Studies / Cultural Studies in Portugal: Some Thoughts on the Making and Remaking of a Field....

\section{Anne Scott Sørensen}

"Something is at Stake": Northern European Cultural Studies - Where, How, and Why? . 89

\section{Aljoša Pužar}

The Boratization Revisited: Thinking the "South" in European Cultural Studies 103 


\title{
European Cultural Studies: Pathways in an Unbound Geography
}

\author{
By Ferda Keskin
}

This collection of texts derives from the international conference 'Current Issues in European Cultural Studies’ arranged in Norrköping, Sweden on June 11-13, 2011 by the Advanced Cultural Studies Institute of Sweden (ACSIS). The particular focus of the conference, which was not exclusive, naturally privileged a framework in which current issues and perspectives pertaining to interdisciplinary, critical and cultural research in Europe were taken under scrutiny. The explicitly stated intention of this exercise was 'to point at the tensions and contradictions that together serve to map key contemporary directions in this complex field'.

The following texts are thus rather a set of conference reports than conventional research articles. They reveal that no internal or internalist account of the tensions and ambiguities constitutive of this complexity, which is manifold, can lay claim to be exhaustive or can justifiably be isolated from an externalist account operating at various levels. In other words, the critical aspect of cultural research and specifically of cultural studies fully appears only within a context relentlessly informed by multifarious relations of power and therefore thoroughly political. This certainly applies to the reflection of cultural studies on itself as an interdisciplinary field and hence to its claims of proximity and distance vis-à-vis established academic disciplines in terms of discursive practices and of the epistemic/methodological procedures they involve. But it also applies to its self-reflection in terms of nondiscursive practices that determine degrees of institutionalisation, strategies of demarcation, geographical designations, and even linguistic monopolies.

It certainly would be impossible to do justice to the ways in which the contributions present in this volume meticulously illustrate and problematize this selfreflection in relation to different cultural and academic configurations. Some reiterations, however, might serve to outline a preview, albeit an incomplete one, of the concern outlined above. Mica Nava's contribution, for example, relates, in the first person singular, certain aspects of the historical relationship between cultural studies and history in the United Kingdom, in order to contextualise the specificity of cultural history through the mediation of her own work on cosmopolitanism. Hence her detailed effort to distinguish her project from sociology, postcolonial theory, conventional as well radical history, feminism, political economy and psychoanalysis works as a demonstrative illustration for the concluding statement that

Keskin, Ferda: 'European Cultural Studies: Pathways in an Unbound Geography', Culture Unbound, Volume 5, 2013: 19-22. Hosted by Linköping University Electronic Press: http://www.cultureunbound.ep.liu.se 
'all theorists [...] produce theoretical propositions as part of their engagement with or against other theorists and bodies of thought in specific historical and political contexts'.

The contacts and conflicts inherent in the intradisciplinary, extradisciplinary, and interdisciplinary dynamics that invest the practice of cultural studies reemerge on further grounds that might even take the form of institutional recognition. Udo Göttlich and Gönül Pultar point out that no official chair or professorship exclusively dedicated to cultural studies can be found in Germany or in Turkey, thus leaving the researchers in this field in some kind of awkward professional ambiguity, if not under the tutelage of established academic traditions. This difficulty seems to be further complicated if such traditions are endowed with an authoritative claim to hold definitive power on the notion of culture, as Göttlich emphasises in his account of the challenge of Kulturwissenchaft(en) and Kultursoziologie to the formation of cultural studies in the German speaking world. The picture gets even more complicated, complex or ambiguous when one is reminded that there is no yet decided-upon rendering of 'cultural studies' into Portuguese and Turkish (and possibly into other European and non-European languages as well), and that translation still depends on inconclusive interpretation of the nature of the kind of research in question.

The question of translating 'cultural studies' is not just a question of conceptual adequacy, and 'language' appears to be a much broader and deeper problem for researchers in the non-English speaking world. The problem seems to be multilayered. In the specific case of Turkey, as Pultar argues, it may take the form of a 'language divide' or 'divorce' between Anglophone scholars and those who are merely Turcophone. This divide is elevated to a higher order, the argument goes, when the two sides mutually disdain each other either because one finds what is published in the local language theoretically uninformed and therefore uninteresting or because the other finds what is published in English irrelevant to Turkish studies. The most pessimistic aspect of this account is revealed in two further claims: that the latter judge the work of the former as 'more often than not demonizing Turks and Turkey'; and that 'one cannot but sense' in the stance of the former 'a whiff of neo-colonization [...] that translates in action into unconscious neo-colonialism'. This indeed is a difficult position for multilingual scholars who are supposed to be unconscious neo-colonialists (possibly demonising their own culture) even when they are trained and work in intellectual traditions of a radically self-critical nature.

The problem would, of course, not be resolved even if English were taken as the main medium of communication and publication. For, as Sampaio quotes from Álvaro Pina (Pina 2000), there often is the dilemma of having to choose between, on the one hand, writing on a local topic and thus reducing the chance to appear on the international scene, and writing, on the other hand, on what is relevant to the English-speaking world and failing one's responsibilities as a public intellec- 
tual where 'public' presumably serves as an adjective to qualify the local. The same concern is expressed by Anne Scott Sørensen who emphasises that 'Cultural Studies from non-English speaking countries and in other languages have to either translate themselves into English - or accept their desolation and absence from international dialogue'. That this is an obstacle not only for the academic career of individual researchers 'but for the very production of knowledge' in the so-called peripheries of a transnational setting is a fact that is already identified in an article by Johan Fornäs and Mikko Lehtonen that Sørensen brings to attention (Fornäs \& Lehtonen 2005).

The line drawn by language is not, however, exhaustive of the divisions to be performed when critical and cultural research in Europe is to be situated. Hence the spotlight sessions of the conference that culminated in this collection had gathered scholars into panel discussions organised on the basis of a geopolitical division of Europe into five regions: central, east, north, south and west. However, as the 'Introduction' to the conference readily admits, the fact that one of these regions was 'actually limited to British cultural studies' indicated that these designations are far from standing for 'innocent concepts', and that there is 'need for strong critical debates around the very idea of dividing Europe in this manner'. Hence the division, far from being 'prescriptive or definite', was expected to serve as a 'heuristic tool to start discussing the inner diversity of cultural studies in this part of the world'.

The difficulty of dividing Europe into well-defined regions and delineating the practice of cultural studies within geographical borders emerges as a fundamental problem in the case of Northern Europe, as Sørensen indicates that a variety of significantly different constellations appear even when one attempts to limit alternative classifications to the categories 'Nordic countries' and 'Scandinavia.' The theme of geographical markers is equally important for Aljoša Pužar not just as a spatial category, but also as a discursive rule engendering identity.

One may think that a possible corollary to this line of reasoning is that the ideas of European cultural studies and of 'regional studies' as established categories are to be called into question and contested from various perspectives.

It has been argued above that an internalist account of the complexity of 'European cultural studies' cannot justifiably be isolated from an externalist account. No externalist account, meanwhile, can claim to be exhaustive, and one would have to observe that the relations investing this kind of research require a global perspective. It is in this respect highly instructive to remember Sampaio's emphasis that relatively recent developments such as the Bologna process and the emergence of 'cultural-turned-creative industries' as part of a shift to the 'new economy' have in Portugal opened alternative ways of understanding cultural studies. Positive as they may seem, such alternative understandings elevate, according to Sampaio, 'culture to a key economic activity', and 'in a context of high academic instability, where job scarcity and precariousness reign supreme’, they impose 
pressures 'on academics and researchers to become increasingly more 'productive', seriously damaging their chances to commit to a more encompassing, truly interdisciplinary and socially-grounded intellectual project'.

It is not hard to see, under this description, the tendency of neoliberalism to extend the logic of market economy and its pervasive principles of entrepreneurship beyond the realm of market itself (an excellent account of this process can be found in Dardot \& Laval 2009). Also not hard to observe, on a larger scale, is that the serious threat humanities and social sciences have been facing within parts of Western academia, has already taken the expected global dimension using the Bologna process as a means to retuning higher education according to the demands of the 'new economy'. Pužar's text bears further witness to this change in the structure of the academia with a special emphasis on the South.

Mapping key contemporary directions in such complexity is still work in progress, and we cannot but be thankful to Johan Fornäs and Martin Fredriksson for the organisation of the 'Current Issues in European Cultural Studies' conference that made this precious selection possible.

Ferda Keskin received his Ph.D. in philosophy from Columbia University. He currently teaches at the Department of Comparative Literature at Istanbul Bilgi University where he directed the MA in Cultural Studies Program from 2003 to 2006. He founded, in the same institution, the BA in Political Economy and Social Philosophy Program and the MA in Philosophy and Social Thought Program. Ferda Keskin served as Chair of the international Association for Cultural Studies from 2008 to 2010. His research and interest areas include Foucault, Social and Political Philosophy, Ethics, Philosophy of Social Sciences, Philosophy and Literature, and Cultural Studies. E-mail: ferda.keskin@bilgi.edu.tr.

\section{References}

Dardot, Pierre \& Christian Laval (2009): La nouvelle raison du monde: Essai sur la société néolibérale, Paris: La Découverte.

Fornäs, Johan \& Mikko Lehtonen (2005): 'Between Centres and Peripheries in Transnational Cultural Studies’, Urpo Kovala, Katarina Eskola, Kimmo Jokinen, Vesa Niinikangas \& Esa Sironen (eds): Tarkkoja siirtoja, Jyväskylä: Research Centre for Contemporary Culture, University of Jyväskylä , www.arthis.jyu.fi/julkaisut/tarkkojasiirtoja/lehtonenfornas.html (accessed 19 April 2013).

Pina, Álvaro (2000): 'Teaching and Doing Cultural Studies in Portugal', Cultstud-L: http://www.cas.usf.edu/communication/rodman/cultstud/columns/ap-30-01-00.html (no longer accessible) 


\title{
Cultural Studies, History and Cosmopolitanism in UK
}

\author{
By Mica Nava
}

\begin{abstract}
This article reviews aspects of the historical relationship between cultural studies and history in the UK university context and illustrates the specificity of cultural history approaches by drawing on the author's own work on cosmopolitanism.
\end{abstract}

Keywords: Cultural studies; history; cosmopolitanism. 


\section{A History of Cultural Studies}

In this brief paper I will review aspects of the historical relationship between cultural studies and history in the UK university context and illustrate the specificity of cultural history approaches by drawing on my own research on cosmopolitanism.

So, first, a very short history of cultural studies at the University of East London (UEL), the university at which I have worked for three decades. UEL was the home of the first undergraduate Cultural Studies degree in the country, founded in 1981. In those days the programme was not modularised and I arrived when the first intake was in its third year so the broad framework of the course had already been established. What was distinctive about its design was that all students had to do a 'core' as well as options in one of three main strands: philosophy, literature or popular culture. Significantly, the core, running through the three-year course, was a more-or-less chronological 'history' beginning in the $17^{\text {th }}$ century, so from the start was an indication of the way different knowledges were prioritized. It was influenced by Raymond Williams' work and focused on the history of class formations and class cultures, 'race' and colonial power, women's lives, popular experience, sexuality, the everyday and the politics of resistance and consent - all the issues you would expect a radical innovative department to be concerned with, but at the time still very unusual. Marx, Gramsci, Foucault, Stuart Hall, Edward Said, Juliet Mitchell, Sheila Rowbotham, Angela McRobbie and Marshall Berman were among the influential thinkers that students (and staff) were expected to read.

The teaching group came from a range of disciplinary backgrounds: sociology, history, literature, philosophy and history of art. A few of us had been linked in one way or another to the now celebrated CCCS (Centre for Contemporary Cultural Studies) at the University of Birmingham. All were on the left. Through the collective teaching of carefully planned courses we taught each other and ourselves. In the 1990s we also produced collaboratively a couple of key volumes of essays using this mix of intellectual approaches: The Expansion of England: Race, Ethnicity and Cultural History, edited by Bill Schwarz (1996a) and Modern Times: Reflections on a Century of English Modernity, edited by Alan O’Shea and myself (1996). ${ }^{1}$

The emphasis on history in our teaching programme and our research meant that from the beginning there was some tension in the group - mostly productive tension - between the 'proper' historians - those who had been trained as historians, whose interest and objective it was to 'uncover' and piece together features and narratives of the past, particularly of an unfamiliar or hidden past - and those whose disciplinary orientation had been developed in sociology and 'theory' and who were more concerned to track the genealogies of the big political questions of 
the present, that is to say those whose interest was conceptually driven. (For a discussion of these historiographical differences see Eley 2005 and Tosh 2006).

In general the direction of the influence between these two broad camps was from cultural studies to history. Over the last decades there has been a tremendous expansion among the more orthodox historians of what counts as acceptable historical source material and how to make sense of it, as well as a more reflexive consideration of the sociopolitical embeddedness and constructedness of all versions of the past.

Cultural studies in Britain has had an impact not only on history in its various traditions but on all aspects of the humanities and social sciences - on sociology, geography, literary studies, gender studies, urban studies, language studies, visual culture, media studies, psychosocial studies, philosophy, anthropology, economics, art history and fine art practice (indeed the plethora of 'studies' on this incomplete list is itself evidence of this shift). All these are among the established university disciplines in the UK that have been transformed by the more iconoclastic, flexible, interdisciplinary, political and contextual approaches of cultural studies. So does this mean - as Jeremy Gilbert suggested in his written introduction to the spotlight session on British Cultural Studies at the 2011 conference Current Issues in European Cultural Studies - that cultural studies and cultural history have lost their critical specificity and usefulness? Not in my view.

\section{Cultural Studies in History: Cosmopolitanism}

I will use my own cultural historical work to illustrate this claim. There are of course many other appropriate examples but my book Visceral Cosmopolitanism: Gender, Culture and the Normalisation of Difference (2007) is what I know best and it does effectively exemplify the shift in that it doesn't fit comfortably into any critical mode except cultural studies-cultural history. This is in broad terms because it privileges argument, draws on an expanded archive (sources include ballet narratives, costume design, department store promotions, contemporary fiction, film, photographs, social science texts, media reports, psychoanalytic theory, biography and autobiography - including my own) and, in the tradition of cultural studies, is less preoccupied with adhering to methodological convention than I think are its closest neighbours, history and sociology.

It is also an example of 'British Cultural Studies' in its thematic focus and its concern with the specificity of postcolonial race relations, cultural difference, gender and everyday life in the UK context.

Yet it was not in the first instance driven by existing conceptual concerns despite my rootedness on that side of the methodological divide. My theoretical and historical interest in cosmopolitanism did not precede my work in the archive. In fact at the time there was practically no scholarly research on the topic. I came across it by chance when I was working in the archive of the department store 
Selfridges looking for evidence of the impact of imperialism on commercial culture before World War One. I found no references to empire at all but a good deal in the founder Gordon Selfridge's own daily syndicated newspaper columns about how pleased he was that London was losing its insularity and becoming more cosmopolitan and modern. He wanted his store to be at the heart of these changes and publicised the launch in 1909 with full-page advertisements in all the major newspapers in the world welcoming customers in twenty-six languages, among them Arabic, Japanese, Hindi, Russian, Yiddish and Esperanto.

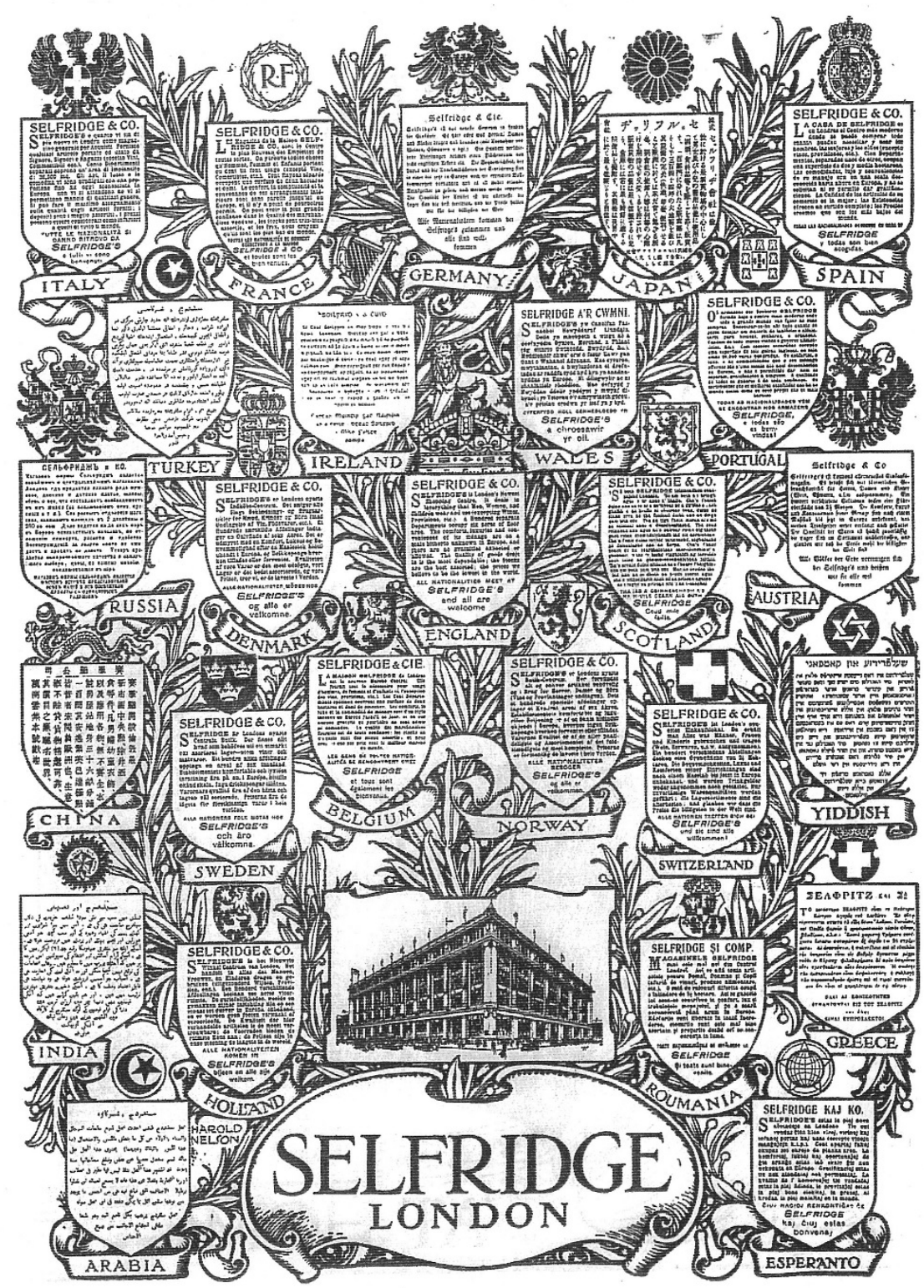

'All nationalities meet at Selfridge's and all are welcome'. Advertisement in twenty-six languages from the launch campaign in 1909. Reproduced with permission of Selfridges Archive. 
As well as being a cosmopolitan moderniser, Selfridge was also an enthusiastic supporter of the contemporaneous movement for women's suffrage. So this was the starting point of my pursuit of historical manifestations of cosmopolitanism across the span of the twentieth century. Although the concept emerged from the archive rather than an already existing theoretical debate, it was nevertheless shaped by the conceptual material I had already been working on - by gender, the everyday, modernity, and commercial culture. This already-established cultural studies groundwork explains the distinctive focus, argument and conclusions of the book.

One of the main concerns of the book was then to explore cosmopolitanism in relation to popular and commercial modernity, to look at its vernacular and domestic expressions. I was interested in the micro-narratives of cosmopolitanism and in everyday personal interaction in the local context, at home, in London, rather than in terms of travel around the world. What emerged from this orientation was an analysis of cosmopolitanism as (following Berman 1983) part of modern consciousness and as (following Williams 1977) a structure of feeling and aspiration. The cosmopolitan disposition in this framework signaled an empathetic, inclusive - albeit semi-conscious and uneven - cluster of identifications with and desire for difference or the 'other', an intuitive sense of self as part of a common humanity with a disregard for borders. This is the 'visceral' cosmopolitanism of the title of the book. The focus is on the allure of difference rather than the repudiation of difference - on antiracism rather than racism.

Another main concern of the book, also rooted in the tradition of cultural studies, is its foregrounding of questions of gender and the position of women in relation to this structure of feeling. This question is notably absent from many recent texts on the broad topic. In the book I argue that women were the historical drivers of cosmopolitanism in twentieth century Britain, in part because of their more intimate relationships with the mainly male migrants from abroad and their greater participation in popular modernity through consumption and the movies. I also argue, more contentiously, that women seem to be more disposed to empathise with cultural others. In the book this assertion is supported by literary and historical examples and psychoanalytic theory.

The focus in the book on the local prompted me to explore the geopolitical and historical specificity of London. How do the meanings and experiences of 'multiculturalism' and epidermal difference differ in London from US cities such as Chicago or other (post)colonial metropolises of the West such as Paris and Amsterdam? What are the differences between UK and other European countries with sizeable intakes of migrant populations? How relevant are the specificity of class formation in the UK and the British privileging of class culture and language to the current outcome?

Similarly, and predictably given the concerns of cultural studies with the 'past', the book sets out to track the historical development of cosmopolitanism in the 
UK, particularly in London, from what was an oppositional culture a hundred years ago to the cultural mainstream today, hence to look at change. This is the 'normalisation' of my title. I attempt to trace cultural and racial difference from 'alterity' to 'mere difference'. The term alterity (drawing on Sennett 2002 and others) expresses the provoking quality of the unknown unclassifiable other.

As the 2012 London Olympics demonstrated, London today is an immensely diverse city in which difference is ordinary. One in three Londoners was born outside Britain and over three hundred languages are spoken by children in London schools. Not only is difference normal, but, as Caribbean-British playwright Kwame Kwei-Armah put it in his radio programme The London Story, 'London is a city at ease with itself', 'proud of its diversity', it is 'the California of Europe', a place which has changed enormously since the 1970s (2010). However, unlike California, London is not only diverse, it is also 'mixed'.

In contrast to the US and elsewhere in Europe, sex and marriage between different cultural groups are now commonplace in UK cities. Although the figures are inevitably contested, it is estimated that about $62 \%$ of young males of AfroCaribbean origin under 30 and in a relationship are with white partners or someone from another ethnic group. The figure for young Afro-Caribbean women is about 50\%. There is a similar tendency among other ethno-religious and 'racial' groups though the figures are lower. It is now estimated that an astonishing $10 \%$ of all children born in Britain as a whole (not just in London) come from a 'mixed' family (Platt 2009). The cultural mixing phenomenon operates across the class spectrum and includes the Queen's cousin who is married to a Nigerian. Diana and Dodi are another instance (Nava 2007). These figures are many times higher than in US or elsewhere in Europe.

This is the process that interested me when I was writing my book, and indeed continues to interest me today. My focus is thus not so much on plurality and coexistence, or on multiculturalism, or even on super diversity (Vertovec 2007) ${ }^{2}$ but on cultural mixing, merger, indeterminacy, fusion and mutuality, on 'mongrelisation' as a historical process, on 'impurity' and 'how newness enters the world' (as Salman Rushdie put it, 1991: 394). Stuart Hall also refers to our 'mongrel selves' to suggest the dissolution of old ways of thinking and being (Hall 1992). Mongrelisation is a contentious term but I find it useful in that it evokes process and change. Following Rushdie and Hall I use it in the title of the final chapter of my book: 'A Love song to Our Mongrel Selves: Cosmopolitan Habitus and the Ordinariness of Difference'.

It is important to stress that the book only explores certain aspects of the culture. As I reiterate throughout, xenophobia, racism and racialised imaginings are tremendously significant currents in the history of twentieth century Britain and have co-existed in varying degrees of tension with cosmopolitanism and antiracism. 


\section{Cultural Studies and Adjacent Disciplines}

So how, more concretely, does the fact that I locate myself in cultural studies and identify myself as a cultural historian distinguish my work on cosmopolitanism from that rooted in other disciplinary approaches?

1. It is different from the work of sociologists like Ulrich Beck who, despite his focus on the 'cosmopolitanisation' of 'the fundamental concepts and institutions of modern society', does not explore the specificity of different countries, historical change or gender or the quotidian practices and feelings of cosmopolitcs (Beck \& Sznaider 2006). My approach is also different from sociologists of cosmopolitanism like Hannerz (1990) and Szerszynski and Urry (2006) who, although more concerned with disposition, focus largely on intellectual and emotional detachment, on seeing difference from afar, not on identification or empathy.

2. It is different on the whole from the work of postcolonial theorists who for very good political and historical reason have focused on the injuries of racial and cultural difference rather than its allure, on racism rather than antiracism (although Stuart Hall and Homi Bhabha both refer fleetingly to the ambivalence and desire which lies at the heart of interracial relations). However, there is some overlap between my 'visceral cosmopolitanism' and Paul Gilroy's notions of 'conviviality' and 'planetary humanism' (2004).

3. Conventional historians have been ambivalent about the notion of 'modernity' and the blending of the textual with everyday culture, as for instance in the eclectic approach adopted by Marshall Berman in his seminal text All That Is Solid Melts Into Air: The Experience of Modernity (1983). The thematic and theoretical concerns of my book and my methodological approach are similarly unconvincing for many historians, though that now seems to be changing.

4. My book also has a different emphasis from the work of the more radical cultural historians whose focus has tended to be on the invention and consolidation of a conservative English 'tradition', on 'conservative modernity', on the legacy of Empire and melancholia about its loss (eg Alison Light 1991; Bill Schwarz 1996b; Chris Waters 1997; Wendy Webster 2005 and contributors to the journal British Cultural Studies writing about the 1950s and 1960s) not on the more positive developments of antiracism and engagement with migrant others.

5. Feminists as well as political economists and sociologists have on the whole not addressed the specific relationship of women to cosmopolitanism (though see Ulrike Vieten 2012 and Nira Yuval Davis 2012). There has been some attention to gender difference in the work on global cities and migrant labour but not much, as far as I am aware, on issues of cultural interaction and the everyday. 
6. Psychoanalysts and theorists drawing on the framework of psychoanalysis have been concerned on the whole to explain the unconscious factors underlying prejudice and the repudiation of difference rather than its attraction, see eg Freud (1930/1963) on the 'narcissism of minor differences'. In general there has been very little interest in the psychodynamics of inclusivity and empathy or in gendered differences in response to belonging and cultural 'otherness'. Ettinger's theory of the matrixial (2004) is among the exceptions.

It is not only a broadly cultural-history interdisciplinary approach which distinguishes my work from that of others concerned with the rapidly expanding topic of cosmopolitanism. There is also the more iconoclastic tradition of 'arguing against' which has characterized much cultural studies research from its inception (Williams 1979) and which here has been combined with my insistence on viewing everything through a feminist lens. My perspective has also been influenced by my personal history and psychic formation, an account of which (in the autobiographical chapter on our mongrel selves) I interweave with the main narrative of the book (Nava 2007). This is where I explain my interest in the topic - a contextual element too often missing from most historical accounts which tend to present themselves as somehow unembedded in the vicissitudes of life outside the text. Finally, it is also worth noting that my conclusions and the way I write - the construction of a more progressive reading of British encounters with cultural and epidermal difference in the last century - arise in part from my generally optimistic albeit argumentative disposition. This is not a problem per se, and is not a disavowal of more melancholic readings, but like all factors which influence our understanding of the past and present, needs to be noted.

So in conclusion: the general message I want to convey here is that cultural studies in Britain, and especially at UEL, has strengthened 'history' and accounts of the past though the boldness and breadth of its themes, archive and method, its use of cultural theory and its consciousness of contextual and biographical factors. Conversely, historical consciousness has also influenced much cultural studies. A questioning of chronology and causal association is likely to yield a more complex picture than is often the case in textual analysis, which is so often the dominant mode in our discipline. We need to contextualise not only our data but also our argument in historical, geo-political and autobiographical terms. As cultural studies scholars we must remember not to invoke and critique theory as though it were produced in a vacuum, without roots. All theorists are people who live at specific historical moments and produce theoretical propositions as part of their engagement with or against other theorists and bodies of thought in specific historical and political contexts. 
Mica Nava is Professor of Cultural Studies and was founder and co-director of the Centre for Cultural Studies Research at the University of East London, UK. Her publications include Changing Cultures: Feminism, Youth and Consumerism (1992), Modern Times: Reflections on a Century of English Modernity (1996), Buy This Book: Studies in Advertising and Consumption (1997) and Visceral Cosmopolitanism: Gender, Culture and the Normalisation of Difference (2007). She is currently investigating the impact of European and American thinking on 'race' relations, gender and cultural mixing in Britain during the 1950s and 1960s. E-mail: m.nava@uel.ac.uk

\section{Notes}

1 Contributors included Sally Alexander, Andrew Blake, Bob Chase, Catherine Hall, Peter Horne, Alan O’Shea, John Marriott, Mica Nava, Ken Parker, Gwyneth Roberts, Bill Schwarz and Couze Venn.

2 Vertovec's notion of super-diversity refers the complex variables, among them class, wealth and education, which disrupt the homogenizing tendencies present in the notion of multiculturalism. But it does not refer to interaction or cultural mixing.

\section{References}

Beck, Ulrich \& Natan Sznaider (2006): 'Unpacking Cosmopolitanism for the Social Sciences: A Research Agenda', The British Journal of Sociology, 57:1, 1-23.

Berman, Marshall (1983): All That Is Solid Melts into Air: The Experience of Modernity, London: Verso.

Eley, Geoff (2005): A Crooked Line: From Cultural History to the History of Society, Ann Arbor: University of Michigan Press.

Ettinger, Bracha L. (2004): 'Weaving a Woman Artist With-in the Matrixial Encounter-Event', Theory, Culture \& Society, 21:1, 69-93.

Freud, Sigmund (1930/1963): Civilization and Its Discontents, London: Hogarth Press.

Gilroy, Paul (2004): After Empire: Melancholia or Convivial Culture, Abingdon: Routledge.

Hall, Stuart (1992): 'Our Mongrel Selves’, New Statesman and Society, 19 June 1992.

Hannerz, Ulf (1990): 'Cosmopolitans and Locals in World Culture', Theory Culture \& Society, 7:2-3, 237-251.

Kwei-Armah, Kwame (2010): The London Story, BBC Radio 4 (July).

Light, Alison (1991): Forever England: Femininity, Literature and Conservatism Between the Wars, London: Routledge.

Nava, Mica (2007): Visceral Cosmopolitanism: Gender, Culture and the Normalisation of Difference, Oxford: Berg

Nava, Mica \& Alan O’Shea (eds) (1996): Modern Times: Reflections on a Century of English Modernity, London: Routledge.

Platt, Lucinda (2009): Ethnicity and Family: Relationships Within and Between Ethnic Groups, London: Equality and Human Rights Commission (EHRC).

Rushdie, Salman (1991): Imaginary Homelands, London: Granta.

Schwarz, Bill (ed.) (1996a): The Expansion of England: Race, Ethnicity and Cultural History, London: Routledge 
Schwarz, Bill (1996b): 'The Only White Man in There: The Re-racialisation of England 1956-68', Race Class, 38:65.

Sennett, Richard (2002): 'Cosmopolitanism and the Social Experience of Cities', Steven Vertovec and Robin Cohen (eds): Conceiving Cosmopolitanism: Theory, Context and Practice, Oxford: Oxford University Press.

Szerszynski, Bronislaw \& John Urry (2006): 'Visuality, Mobility and the Cosmopolitan', The British Journal of Sociology, 57:1, 113-131.

Tosh, John (2006): The Pursuit of History, London: Pearson.

Vertovec, Steven (2007): 'Super-diversity and its Implications', Ethnic and Racial Studies, 30:6, 1024-1054.

Vieten, Ulrike (2012): Gender and Cosmopolitanism in Europe, London: Ashgate.

Waters, Chris (1997): “"Dark Strangers” in Our Midst: Discourses on Race and Nation in Britain, 1947-1963’, Journal of British Studies, 36 (April), 207-238.

Webster, Wendy (2005): Englishness and Empire 1939-1965, Oxford: Oxford University Press.

Williams, Raymond (1977): Marxism and Literature, London: Oxford University Press.

----- (1979): Politics and Letters, London: New Left Books

Yuval Davis, Nira (2012): The Politics of Belonging, London: Sage. 


\title{
Cultural Studies and Sociology of Culture in Germany: Relations and Interrelations
}

\author{
By Udo Göttlich
}

\begin{abstract}
Over the last three decades, attitudes towards cultural studies in Germany have developed within contexts of contact and conflict with a variety of disciplines, e.g. ethnology, anthropology, sociology, as well as the sociology of culture, literary studies and Kulturwissenschaft(en). On the one hand there is a strong academic interest in how cultural studies perceives and analyzes media culture, popular culture and everyday life. On the other hand boundaries with humanities and social science remain, which leads to criticism and conflicts with cultural studies and its achievements.

I will discuss some of the problems concerning the perception and reception of cultural studies among representatives of Kulturwissenschaft(en) and sociology of culture. Furthermore I will draw on the role of cultural studies in thematizing cultural change and conflicts, and its ability to do so in a way that shows the importance of culture and politics.
\end{abstract}

Keywords: Sociology of Culture, Kulturwissenschaft, Geisteswissenschaft, Media and Cultural Studies, Inter- and Transdisciplinarity. 


\section{Pinpointing Cultural Studies in the German-speaking Region}

We can distinguish three different phases of the reception of cultural studies in the German-speaking region as well as in Germany itself over the last three decades. ${ }^{1}$ The first phase started in the 1970s and focused on questions of ideology and the analysis of youth culture with emphasis on forms of resistance and styles in youth culture that developed off the beaten path in ethnography, educational science and sociology of culture in the 1980s (cf. Göttlich \& Winter 1999). ${ }^{2}$

During the late 1980s, the focus of the second phase turned more and more on popular culture as a whole, as well as on media and television studies in the early 1990s. Television texts and audiences became a contested area for cultural studies and the established media- and communication studies. Especially the implementation of Hall's "encoding/decoding" model, the analysis of an "active audience" in the work of Morley, Ang and Fiske as well as questions of media reception were a site of struggle for cultural studies and media- and communication studies.

The third phase, beginning in the late 1990s, is characterized by a scope on the culture of everyday life and questions of identity, perpetuated by different research projects in the fields of European ethnography and Kulturwissenschaft(en). These questions of identity and power in a global media sphere became a central topic in media studies at the turn of the new century as well. Besides these main areas of interest that show strong relations to media- and communication studies and Kulturwissenschaft(en), cultural studies placed particular interest on gender studies and on the record of qualitative research methods. This reception is paralleled by the reception of the "cultural", "practice" and "performative turn", that is more or less judged as cultural studies related, even when it is not.

Taking this short sketch of the reception of cultural studies in the Germanspeaking region as a starting point for my discussion on the current relationship of cultural studies with Kulturwissenschaft(en) and/or Kultursoziologie (sociology of culture), one can say that attitudes toward cultural studies have developed in contact as well as in conflict with a variety of disciplines, e.g. ethnology, anthropology, educational science, sociology, the sociology of culture as well as media and literary studies.

Generally speaking, this broad reception of cultural studies over the last thirty years indicates a strong academic interest in how cultural studies perceives and analyzes popular culture, media culture and everyday life. Against this background, cultural studies in Germany as well as the German-speaking region cannot be considered as a "newcomer". However strangely, not a single German university institute, chair or professorship exclusively dedicated to cultural studies can be found. Instead, there are university institutes and research projects, mainly within the field of media studies, which make use of cultural studies in an interdisciplinary understanding. In short: Whereas cultural studies, although it is not a discipline in itself, has achieved an identity of its own in the UK, Australia and 
the US, cultural studies in Germany as well as in the German-speaking region has not yet reached that state.

Despite the broad reception, there are still remaining boundary lines between cultural studies, humanities and social science, which still lead to criticism of cultural studies and result in conflicts about its achievements. Even though most of the conflicts seem to be resolved, still many theoretical and methodological problems remain. Especially when we focus on the relationship of Kultursoziologie with cultural studies within the field of German sociology, we also encounter different traditions of cultural criticism. Beneath these differences that become evident through reflecting on this relation, lies the assumption that "of all sociology's 'strange others', cultural studies is perhaps the least unfamiliar" (cf. Inglis 2007: 99), as Inglis had pointed out for British cultural studies.

The reason for the ongoing existence of struggle with these differences in cultural criticism is interesting as it originated from the cultural studies' way of dealing with questions of culture, which generated new interest in the sociology of culture at the beginning of the late 1980s. For many students of sociology a new perspective on culture was brought forth, whereas the Kultursoziologie in the tradition of Weber, Simmel or Mannheim, as well as the critique of the Frankfurt School were deemed to be "too special stuff" even for the academic teachings of many universities at that time. The problems that grew out of this special situation lead to different questions of possible disciplinary combinations, despite the ongoing opposition of cultural studies with the sociology of culture as well as Kulturwissenschaft(en). The process of managing the challenges between the different academic cultures is by no means trivial. ${ }^{3}$

The underlying question, why cultural studies has to face such a bold opposition from other disciplines, can be answered in two ways. On the one hand it is argued that cultural studies is still a "young” and emerging field, which has yet to find its own identity and particularly a German perspective. On the other hand it is argued that there are already many fields in German academia that deal with questions of culture and communication and whose divergent perspectives cannot be easily combined. Nevertheless, these different concepts of culture are still helpful for theorizing cultural developments or problems. However, they hinder scientific research and development, when they are used as ideological "entrance requirements". Considering these fault lines of argumentation, I propose a sociology of culture within cultural studies. Through this, it is possible for all sides in this game to benefit from each other.

To do so, we briefly have to look at the specific ways Kulturwissenschaft(en) and German sociology recognizes cultural studies, in order to understand the ongoing oppositions. Based on this, I will point out how to handle these different positions and discuss the role of the sociology of cultural studies for further research. ${ }^{4}$ 


\title{
What is Culture Anyway?
}

Up to now, as many of you know, the term "culture” is not used lightly, especially in Germany and the German language. In German academia, the Geisteswissenschaft, i.e. the humanities, claim to hold definitory power on questions on culture. Hence, the term culture serves as a theoretical concept and sometimes certain kinds of "Welt-Anschauung" are connoted. This defines the first borderline between cultural studies and (I) Kulturwissenschaft(en) as well as (II) Kultursoziologie in the traditional understanding:

(I) According to Geisteswissenschaft - whose offspring is Kulturwissenschaft(en), and which has designated this "youngster" as its legitimate heir - cultural studies are only narrowly interested in phenomena of "everyday life", and social practices, rather than focusing on broader questions of "Sinn" ["meaning”]. But can this be considered the main reason for the opposition or is this only a surface, which conceals the "true" reasons for this antagonism towards cultural studies' way of dealing with culture?

For example, in an introductory-level textbook on Kulturwissenschaft by Hartmut Böhme and colleagues (2000), intended to give students orientation in the field of Kulturwissenschaft(en), there are only three pages on cultural studies, given in the form of opening remarks that indicate the still existing borderline. Scrutinized closely, these pages revitalize stereotypes of cultural studies and position them in opposition to culture - i.e., to culture in the sense in which the Geisteswissenschaften normally use the term. In my opinion this does not contribute to a deeper understanding of cultural studies.

The further arguments of this textbook emphasize that cultural studies

\begin{abstract}
is [after all the years of academic success in the UK and USA; UG] no theoretical concept or theory that is solid and that stands against the backdrop of a consensus. Terms like "contextualization" signal, with respect to method, that only heterogeneous elements are combined. "Othering" is just another term for the alliance of ethnography and cultural anthropology. "Mapping" tends to give cognitive maps of cultural phenomena and the discurse on minorities works as an instrument to differentiate and to particularise the collectivised individual culture [Kollektivsingular; UG].
\end{abstract}

For the authors "the risks of this development are evident” because

within the sphere of influence of ethnic and minority groups, the term culture tends to lose its analytical and synthetical function within ideological critique. The place of the traditional canon is taken by a poorly considered new canon of particularities combined in an additive way. (Böhme et al. 2000: 13)

In my opinion, this passage gives a good impression of how cultural studies are perceived by the Kulturwissenschaft(en) and how in a certain way the inherent problems of the term "culture" remain unresolved.

(II) Apart from this opposition with Kulturwissenschaft(en), there are only slight differences in cultural studies’ relationship with sociology. Once more In- 
glis can be cited, as he hints that cultural studies and the sociology of culture are but warring twins. For him,

[t]hey 'agree to have a battle', because the battle brings certain gains in identity for them both. But beyond rhetorical displays of dissimilarity between them, once one examines their shared epistemological assumptions, one sees that it is actually their very likeness that compels them to engage in the ritualized conflicts they embark upon. (Inglis 2007: 118)

This situation came to fore, when cultural studies was heavily critized by sociologist working in the phenomenological tradition in the early 1990s. One argument was that cultural studies does nearly the same sort of ethnographic research of everyday practices that in the end must be judged as a certain drift from the sociological trail while looking for the politics of the everyday life. Further arguments for the conflicts emerging from this "similarity" cannot be discussed here. Instead, I will give some hints on how to overcome the conflicts and opposite positions both sides stick to when the term "culture" is mentioned - even when there is a common ground. I will show that there is a special sociology of culture within cultural studies. From this vantage point, it is possible to overcome the abovementioned problems: we can start to build a formation of cultural studies in Germany as well as a transdisciplinary setting for the study of culture.

\section{A Formation of Cultural Studies in Germany?}

Generally speaking, the reception of cultural studies is symbolic for the opening of German-speaking academia towards new horizons in the Kulturdebatte (cultural debate and criticism) over the last thirty years. This serves as a good starting point not only to discuss the specifics of sociology of culture within cultural studies. Furthermore, if cultural studies deals with questions of culture, we have to make clear, why the ongoing critique of cultural studies in Germany is based on assumptions that Kultursoziologie has to say more about culture than cultural studies.

The problem stems from the term "culture" itself and its associations. To prevent further misunderstandings, we can refer to Grossberg's latest book, in which he rejects the idea that cultural studies is about culture (cf. Grossberg 2010: 8). If that is the case, I doubt that things might become clearer in the German-speaking region. If cultural studies is not about culture anymore, it must be about power, as this is cultural studies' second object of research, which is highlighted in many discussions. And many practitioners of cultural studies highlight this aspect too. As a result, the concepts of "power" and "culture" are often dealt with in an essential or substantial understanding. By turning to the question of culture, cultural theory can help to foster a sociological understanding of power and culture, instead of turning backwards towards essential or substantial definitions. 
One way to "sociologize" the term "culture" for cultural studies is to put an emphasis on an understanding of culture as ongoing processes, or as practices. This point of view is provided by Raymond Williams and further perpetuated by Stuart Hall. In this perspective, cultural studies' methodological value derives from Williams' basic principle of avoiding language that massifies others (Williams 1958: 306). Williams' suggestive formulation relates “culture” to the sum of the available descriptions through which societies make sense of and reflect their common experiences. Shortly, this is the point where cultural studies deals with questions of cultural practices in a sociological way, regarding the understanding and thematizing the production and reproduction of everyday social life. This prospective comes along with questions or problems of power and hegemony, already described in the early works of Thompson and Williams. In line with this understanding, we can follow Grossberg's arguments a little bit further:

Cultural studies [...] is concerned with describing and intervening in the ways cultural practices are produced within, inserted into, and operate in the everyday life of human beings and social formations, so as to reproduce, struggle against, and perhaps transform the existing structure of power. (Grossberg 2010: 8)

And following these self-imposed tasks, cultural studies itself becomes a certain kind of practice. Taking these arguments into consideration, we have to discuss a way that allows us to deal with the problem of power within cultural theory (next to a bundle of sometimes more important questions than power). For example, questions of how these practices reproduce culture and society come to mind. At this point, we are dealing with the core questions of Kultursoziologie as well as parts of Kulturwissenschaft(en) - despite of them being the "opposite" of cultural studies. Based on the historical reception of cultural studies in Germany, it now becomes evident why many scholars have overlooked cultural studies. It is not about culture or power, it is about different practices of culture and power. To achieve an initial turn towards this perspective, we can reformulate this special understanding, as (once again) Grossberg did in his book Cultural Studies in the Future Tense. "Culture" is the deepest and most solid rock of our common sense.

Instead, too often, the concept of culture - and other related categories - is assumed, appropriated, generalized and even universalized. (Grossberg 2010: 169)

In my opinion, this holds true for the notion and concept of power as well. If we consider these arguments, we can imagine how the academic struggle for the term "culture" leads to nothing more than to fortified oppositions. The main difference between cultural studies and sociology of culture cannot be found in their definitions of the terms "culture" or "power" or in their forms of cultural criticism, but it can be found in the disciplines' ideas on cultural processes, practices, contexts, power and everyday life.

If we compare the agendas of the sociology of culture and of cultural studies under these terms, we can start to consider if it is worthwhile to search for an 
agenda based on compromises and interdisciplinarity or to dismiss that thought and continue with one's own ways.

If "[...] cultural studies is not about interpreting or judging texts or peoples, but about describing how people's everyday lives are articulated by and with culture”, then "(c)ultural studies is about the historical possibilities of transforming people's lived realities and the relations of power within which those realities are constructed and lived, and it is about the absolutely vital contribution of intellectual work to the imagination and realization of such possibilities." (Grossberg 1999: 24)

From this point of view, only cultural studies can be defined as political in the strict sense of the term; namely as proactive. That means that cultural studies do not work in a way that Meaghan Morris critized by telling us

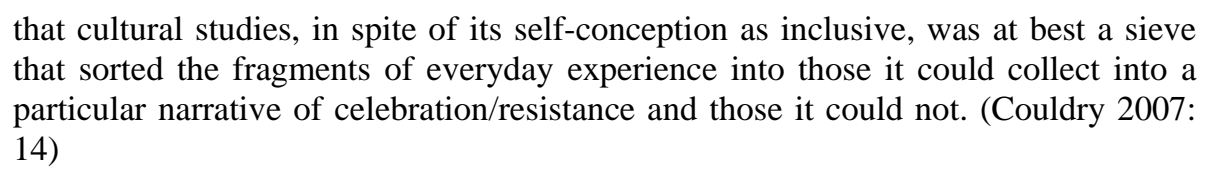

If this development proves true, the outcome is not far away from the ideas brought forth by the adversing perspectives. But we can argue that Kultursoziologie as well as Kulturwissenschaft(en) place themselves "above the battlefield" and abstract themselves from the phenomena of everyday life. Given this description, one has to ask if the need exists to bring together cultural studies and sociology of culture and/or Kulturwissenschaften in the German-speaking region to reach the aim of building an own formation. Perhaps cross-fertilization with regard to intellectual questions is beneficial; if this is the case, these questions can only be addressed by defining how this intellectual work matters. The powerful position held by traditional perspectives on culture like Kulturwissenschaft is deeply rooted in the history of the German university system, and therefore has a certain impact on the role and self-perception of scholars in this field. From this point of view, cultural studies in German-speaking countries have to face the problem that the Kulturwissenschaften in some ways tries to substitute itself for cultural studies in order to evade, to efface, the political implications of the newer discipline.

\section{Conclusion}

If there is to be a chance for a cultural studies formation in Germany, then there can be no trivial answers to the above-mentioned questions. The idea of crossfertilization with Kultursoziologie or Kulturwissenschaft brings up more questions than it can answer. And the way to discuss the sociology of cultural studies is faced with the assumption that sociologies "strange others" are not of sociology (cf. Göttlich 2007).

While the question of how the positions of sociology of culture and cultural studies can cross-fertilize each other seems to be a logical one, I doubt that bring- 
ing together such different intentions can help to overcome the academic borderlines. Individual scholars can cross, or even abolish these for them - but these rifts are still maintained - directly behind the backs of scholars who decide to meet with open minds.

Through such combinations, cultural studies runs the risk of becoming one item in the academic "garbage can”, as Dirk Baecker (1996) points out with regard to Kulturwissenschaften. And - even if there is a good reason to combine the positions of sociology of culture and cultural studies - we further have to face the question of how this may help academic circles in the German-speaking region to overcome their "fear" of the popular (culture), especially when cultural studies is seen as popular culture's strongest agent.

In my opinion, it would be better to appreciate cultural studies as a constant demonstration of what can be contributed by this sociologically concerned and active position, rather than to search for a cross-fertilization that will not help to overcome the borderlines between both traditions. Cultural studies cannot provide another discipline based on an excuse for losing touch with the phenomena of everyday life and its politics. It is, like Nick Couldry pointed out, a concern to hear the range of voices that characterize the social terrain, and not to reduce their complexity. But this concern overlaps with cultural studies' "politics": its aim of responsibly accounting for others in its account of the social world (cf. Couldry 2000: 126-130).

It is not my intention to create unnecessary borders. But considering the long history of the reception of cultural studies in the German-speaking academia, one can only be astounded by the arguments in this confrontation, which go around in circles and do not reach the next step that lies in the challenge of transdisciplinarity.

Udo Göttlich, Dr. M.A., (*1961), Professor for Media and Communication Studies, Zeppelin University, Friedrichshafen, Main research interests: Sociology of Culture, Media and Communication Studies, Cultural Studies. E-Mail: udo.goettlich@zu.de

\section{Notes}

Speaking of cultural studies in Germany or the German-speaking region is not coincidental. There are substantial differences in the reception of cultural studies in Austria, Switzerland and Germany. These are due to different occassions that lead to the contact with cultural studies and different university systems, although the perspective on culture often shares the same disciplinary roots within the Geisteswissenschaften. Nevertheless, it cannot be avoided to use the unifying term "region", although the problems of cultural studies are referred to, 
treated and considered differently in accordance to the countries' academic institutions. When discussing the relationship of cultural studies with the sociology of culture, I will mostly refer to the situation in Germany.

2 These findings account for the academic reception of cultural studies in Western Germany and can only be partly transferred to the reception of cultural studies in the GDR. These took part in the 1970s and early 1980s with a special interest in the analysis of youth culture and the work of Raymond Williams. After the fall of the Berlin Wall this special Marxist-related perspective on cultural studies was not continued.

3 We have worked on this topic in different academic circles and on different occassions in conferences and workshops within the Deutsche Gesellschaft für Soziologie as well as the Deutsche Gesellschaft für Publizistik- und Kommunikationswissenschaft since the 1990s.

4 I will focus only in the main lines of argumentation in the reception of cultural studies over the last thirty years.

\section{References}

Baecker, Dirk (1996): "Auf dem Rücken des Wals. Das Spiel mit der Kultur - die Kultur als Spiel”, Carsten Winter (ed.): Kulturwissenschaft. Perspektiven, Erfahrungen, Beobachtungen, Bonn: ARCult Media, S.305-321.

Bromley, Roger, Udo Göttlich \& Carsten Winter (1999): Cultural Studies. Grundlagentexte zur Einführung, Lüneburg: zu Klampen Verlag.

Boehme, Hartmut, Peter Matussek \& Lothar Müller (2000): Orientierung Kulturwissenschaft. Was sie kann, was sie will, Reinbek b. Hamburg: rowohlt.

Bundesministerium für Wissenschaft und Verkehr u. Internationales Forschungszentrum Kulturwissenschaften (ed.) (1999): The Contemporary Study of Culture, Wien: Turia + Kant.

Couldry, Nick (2000): Inside Culture, London: Routledge.

------ (2007): “Soziologie und das Versprechen der Cultural Studies”, ÖZS (Österreichische Zeitschrift für Soziologie), 32:4, 14-20.

Göttlich, Udo (2007): “Editorial. Die Soziologie der Cultural Studies”, ÖZS, (Österreichische Zeitschrift für Soziologie), 32:4, 3-13.

Göttlich, Udo \& Carsten Winter (1999): "Wessen Cultural Studies? Die Rezeption der Cultural Studies im deutschsprachigen Raum”, Roger Bromley, Udo Göttlich \& Carsten Winter (1999): Cultural Studies. Grundlagentexte zur Einführung, Lüneburg: zu Klampen Verlag, S.25-39.

Göttlich, Udo \& Rainer Winter (eds) (2000). Politik des Vergnügens. Zur Diskussion der Populärkultur in den Cultural Studies, Köln: Herbert von Halem Verlag.

Grossberg, Lawrence (1999): “Globalization and the 'Economization’ of Cultural Studies”, Bundesministerium für Wissenschaft und Verkehr u. Internationales Forschungszentrum Kulturwissenschaften (ed): The Contemporary Study of Culture, Wien: Turia + Kant, .23- 46.

----- (2010): Cultural Studies in the Future Tense, Durkam and London: Duke University Press.

Hörning, Karl H. \& Rainer Winter (ed) (1999): Widerspenstige Kulturen. Cultural Studies'als Herausforderung, Frankfurt a.M.: Suhrkamp.

Horak, Roman (1999): "Cultural Studies in Germany (and Austria): And Why There is no Such Thing, European Journal of Cultural Studies, 2:1, 109-115.

Inglis, David (2007): “The Warring Twins: Sociology, Cultural Studies, Alterity and Sameness”, History of Human Sciences, 20:2, 99-122.

Musner, Lutz (1999). "Locating Culture in the US and Central Europe - a Transatlantic Perspective on Cultural Studies”, Cultural Studies, 14:4, 577-590.

Williams, Raymond (1958): Culture and Society: 1780-1950, London: Chatto \& Windus. 



\title{
Cultural Studies in Turkey: The State of the Art
}

\author{
By Gönül Pultar
}

\begin{abstract}
Recent socio-political developments have rendered cultural studies of the Republic of Turkey an ever-widening field of study, as they lead apparently to a probable paradigm shift in a society that was once thought to be purely Westernoriented. The analysis of this transformation is before all else a cultural studies task. Accordingly, this paper has two aims: one, to make a a brief survey of cultural studies work that has been done so far in Turkey; and two, draw attention to the various problems encountered by the instruction and practice of cultural studies in the country.
\end{abstract}

Keywords: Cultural studies courses, Ege Cultural Studies Symposium, Cultural Studies Association, university programs, problems encountered. 


\section{Introduction}

Recent socio-political developments have rendered cultural studies of the Republic of Turkey an ever-widening field of study. Since the accession to power of Recep Tayyip Erdoğan's pro-Islamic Justice and Development Party (JDP) in the autumn of 2002 (-present), cultural allegiances and pacts of forgetting, whether they be ethnic, religious or ideological, are being realigned, restructured or renegotiated. These are leading apparently to a paradigm shift in a society that was once thought to be purely Western-oriented. Questioning both the foundational maxims and the insistent new requests has become a cultural studies task.

This leads perforce to another, even more immediate task, that of taking a close look at cultural studies in Turkey. This essay aims accordingly to present the current state of cultural studies in the country. It discusses the history of cultural studies instruction and practice and notes the existing university programs, then examines the major problems facing the practice of cultural studies in Turkey today. It is hoped that the information it provides will serve as reference for anyone interested in the subject.

This essay argues moreover that the current state of cultural studies in Turkey renders it incapable of appraising fully the present situation in which Turkey finds itself.

\section{From its Beginnings to its Present State}

\section{British Council Courses}

As noted at the beginning of an article on the education and practice of cultural studies in Turkey by Gönül Pultar and Ayşe L. Kırtunç, it is difficult to pinpoint the exact time when cultural studies began in Turkey as scholars who became cognizant of the "cultural turn" applied its methodology in the courses that they gave long before any formal departmentalization, or opening of courses so labeled occurred (see Pultar \& Kırtunç 2004). It is a fact, however, that the British Council representation in Turkey began in 1992 in Istanbul "British cultural studies" courses. As Laurence Raw, who organized the courses and was himself one of the instructors, explains, the courses were

\section{9-month courses on British and Comparative Cultural Studies, including units on na- tionalism, multiculturalism, class, gender and race. Very British-focused, with topics of little interest to local audiences; however, the Council did offer scholarships for students to go and complete an MA in Warwick. ${ }^{1}$}

The courses were given by, besides the Briton Raw, employed at the time at the British Council, two Turkish academics, Cambridge-educated Cevat Çapan, professor of English language and literature currently at Yeditepe University in Istanbul, and Cem Taylan (1946-2001), also a professor English language and literature, who was teaching at the Western Languages and Literatures department of 
Boğaziçi University (see Raw and Taylan 1993/1994 on their experience of teaching these courses). The British Council started in 1993 courses in Ankara, taught by Can Abanazır (1953-2012) of the Department of English Language and Literature at Hacettepe University. Then in 1995 the British Council started such courses in İzmir; these were taught by Oxford-educated Pete Remington teaching at the time at the American Culture and Literature ${ }^{2}$ department at Ege University, and Andrew Fletcher. These courses were "organized in collaboration with the $U$ of Warwick, Centre for British and Comparative Cultural Studies (which later became the Centre for Translation and Comparative Cultural Studies before being closed in 2007)," as Raw indicates (e-mail message to author, 26 August 2011).

Along these courses and "initially planned as a resource for comparative cultural material" (Raw, e-mail message to author, 26 August 2011). the British Council representation in Turkey started a cultural studies website entitled "CSSG Cultural Studies Study Group" (http://warlight.tripod.com/) maintained by [the Turkish] Cenk Erdil, and last updated on 16 September 1999. Listed at the top of the webpages of the site is "Cultural Studies in Turkey."

"The program came to an end in 1999," as Raw puts it, "when the then Director of the British Council decided to put all their money into English Language Teaching, and opened a Teaching Center in Istanbul" (Raw, e-mail message to the author, 26 August 2001). ${ }^{3}$

\section{Ege Cultural Studies Symposium}

The American Studies Association of Turkey (ASAT) organized in the spring of 1995, on 10-11 April, a two-day "cultural studies" seminar at Ege University, in collaboration with the American Culture and Literature department of that university. The beginnings of cultural studies in this country, for the writer of these lines, is thus the work initiated by Americanists, among them the then three active members of ASAT: Gülriz Büken (then member of the Department of History at Bilkent University, president of ASAT 1994-2011), Ayşe Lahur Kırtunç (then member of the Ege University American Culture and Literature department, and later its Chair), and Gönül Pultar (then member of the Department of English Language and Literature at Bilkent University, vice-president of ASAT 19942000, founding editor-in-chief of Journal of American Studies of Turkey [JAST], and later founding president of the Cultural Association of Turkey 2005-present). These scholars were cognizant of the cultural turn through not only their individual interests and international contacts but also their association with such colleagues as Raw, who taught at Bilkent University before integrating the British Council, and Remington, teaching at the Ege University American Culture and Literature department, as well as younger colleagues who were returning from postgraduate studies they pursued in universities in the West where they had specialized in cultural studies. ${ }^{4}$ 
The Ege April 1995 seminar took place in one auditorium only, with solicited presenters delivering papers to an audience made up of interested faculty members, guest faculty from neighboring Eylül University, and students probably compelled to attend. Titled "The Red, the Black and the White," it was an exercise in US ethnic studies. ${ }^{5}$ By common accord, it was decided it would be repeated on a larger scale, and Ege University through the person of Prof. Seçkin Ergin, then Chair of its Department of American Culture and Literature, agreed to play host to it annually. Kırtunç took over the responsibility of the organization of what was to become a full-fledged conference, and the next year, tapping into her own international contacts and network of colleagues, announced it worldwide. ${ }^{6}$ The number of participants of this first Ege University International Cultural Studies Symposium, organized in 1996, immediately rose to almost 150.

Dubbed CSS - Cultural Studies Symposium, and organized in the month of May annually until 2005, the conference has been organized biannually since. Titled "Change and Challenge," the "Ege University 13th International Cultural Studies Symposium" took place on 4-6 May 2011. All conference proceedings are being published. ${ }^{7}$

CSS was focused at first on Anglo-American topics, and conducted solely in the medium of instruction of the organizers, i.e. English. ${ }^{8}$ However, the Turkish element seeped in quickly. Papers on Turkish themes found a place in the symposia, and subsequently in their proceedings - a state of affairs that was only natural for a discipline such as cultural studies that is by definition inimical to boundaries. Thus, an audience basically made up of Turks found themselves listening to papers in English on purely Turkish topics. A case in point is the paper presented by sociologist Nuran Erol in 1999 on arabesk music ${ }^{9}$ (see Erol 2000). The discussion that ensued, on a purely Turkish predicament, was conducted in English by Turkish participants - and seemed incongrous.

It is basically to remedy this incongruity that a group of scholars got together in the fall of the same year in Ankara to form a "Group for Cultural Studies in Turkey."

\section{The Group for Cultural Studies in Turkey / Cultural Studies Association (of Turkey)}

As noted above, the formation of this group originated from the İzmir conferences, and among its (eleven) members ${ }^{10}$ were several scholars who had been organizing and/or attending CSS. The feeling that led to forming a group was that if cultural studies is to be pursued in Turkey on matters to do with Turkish culture, it should be done first and foremost in Turkish.

One other consideration may have been, although this was never openly voiced as far as I know, the wish to extricate cultural studies in Turkey from the monopoly of the British. None of the members, except for Laurence Raw, could have known that the British Council had terminated its courses. The webpage was there 
(and still is), provided by the British, with the ambiguous "Cultural Studies in Turkey" heading.

Almost all the members of the Group had had prior experience in associations, and the general feeling at first was that this inter-university group could - and should - hold out without formalizing its existence. This was without counting with the need to obtain financial support. When The Turkish Science and Technology Foundation (Türkiye Bilimsel ve Teknik Araştırma Kurumu - TÜBİTAK) started to give out funds for which the Group could apply for its conferences, they believed however that there was no way but to be institutionalized. Thus Kültür Araştırmaları Derneği (KAD, Cultural Studies Association) was founded in March 2005, in Istanbul where Gönül Pultar, who had been elected Chair of the Group at its second meeting in November 1999, had moved (see www.kulturad.org). As there was no radical break from "group" to "association," this essay will consider the activities of the two together (see the chapter "Recognizing Difference: Interdisciplinarity and the Cultural Studies Association" in Raw 2011).

\section{Conferences and Collections of Essays}

The Group, which started meeting once a month, began its activities very modestly with a two-day seminar, with solicited speakers and invited participants, on the subject of migration in early summer 2000 at METU, organized by Group member Yildirım Yavuz. It then launched what was to become biannual conferences, with the one in Kemer, Antalya in fall 2001 entitled, as translated into English, "Modernity and Culture." The book which came out of it is Kültür ve Modernite (Culture and Modernity), edited by Pultar, Emine O. İncirlioğlu and Bahattin Akşit (both Group members) and published in 2003.

This was followed two years later by the, as translated into English, "Cultures of Turks / Cultures of Turkey" conference organized in the southeastern city of Van in 2003 jointly with Yüzüncü Y1l (Hundredth Year) University. The book to come out was Türk(iye) Kültürleri (Cultures of Turks / Cultures of Turkey), edited by Pultar and Tahire Erman (Bilkent University), and published in 2005.

It is as KAD that a conference was held in 2005 jointly with Koç University (Istanbul) entitled, as translated into English, "Identity and Culture." Two books came out: Kimlikler Lütfen: Türkiye Cumhuriyeti'nde Kültürel Kimlik Araylşı ve Temsili (Identities Please: Quest for and Representation of Cultural Identity in the Republic of Turkey) in 2009, and A ğır Gökyüzünde Kanat Çırpmak: Sovyetsonrası Türk Cumhuriyetlerinde Kültürel Kimlik Arayışı ve Müzakeresi (Flapping Wings in Heavy Skies: Quest for and Negotiation of Cultural Identity in the PostSoviet Turkic Republics) in 2012, both edited by Pultar.

KAD also organized in Istanbul, in the fall of the same year (2005) a two-day English-language seminar in collaboration with then Heidelberg-based MESEA (Society for Multi-Ethnic Studies: Europe and the Americas) entitled "Ethnic 
Identity?: (Trans)National and (Bi/Multi/Poly)Cultural Aspects." The book that came out of it, the collection of essays entitled Imagined Identities: Identity Formation in the Age of Globalization, edited again by Pultar, is forthcoming from Syracuse University Press in the fall of 2013.

The next year, KAD organized another conference, in the city of Kütahya (the ancient Kotyaion/Cotyaeum) in Western Anatolia, in collaboration with the municipality of that city. It was focused on a specific subject, "Idil (Volga)-Ural Studies" as translated into English, on the culture of the ethnic groups of the Volga-Ural region (home to the three autonomous Turkic republics of Tchuvastan, Tatarstan and Bashkortostan) within the Russian Federation. The working languages of this international conference were Turkish, English, Russian and Tatar.

The next biannual KAD conference, entitled "E/Im/Migration" as translated into English, took place in 2007 in Şile, a suburb of Istanbul, organized with Iş1k University, boasting of a campus directly on the sea in that popular sea resort town. It was followed in 2009 by a conference in the Black Sea city of Zonguldak (famed for its coal mines), in collaboration with the Karaelmas (Black Diamond) University (since April 2012 "Bülent Ecevit University" ") in that city, entitled, as translated into English, "Black Diamond 2009: Media and Culture." Its proceedings were published the same year as Karaelmas 2009: Medya ve Kültür, edited by Nurçay Türkoğlu (Marmara University), the KAD member who organized the conference, and Sevilen Toprak Alayoğlu (Marmara University).

The last biannual KAD conference to date was organized on 8-10 September 2011 by the current vice-president Emine O. İncirlioğlu (Maltepe University). Entitled "Space and Culture" as translated into English, it was co-organized with Istanbul's Kadir Has University and took place at that university (situated on the Golden Horn, and housed, in much the same way as the Norrköping campus, in the buildings of a tobacco factory). Over 250 participants attended. The proceedings were published as Mekân ve Kültür (2011), edited by İncirlioğlu and KAD member Barış Kılıçbay (Abant İzzet Baysal University).

Two activities are planned for 2013. A workshop on Turkish-Americans, coorganized with Kadir Has University, will take place in June at that university; and the biannual conference, entitled "Memory and Culture" as translated into English, will take place in September in Ankara, co-organized with Bilkent University. And a bilingual online publication, titled KULTUR-e, is planned for 2014 if not earlier.

\section{Cultural Studies Programs in Turkey}

It is also in the fall of 1999 that cultural studies formally appeared in the country's universities with the opening of two graduate programs, at Istanbul Bilgi and Boğaziçi universities, and one undergraduate program at Sabancı University. Another graduate program opened in 2002 at Middle East Technical University. My 
discussion of these programs will be very brief as the Pultar and Kirtunç essay of 2004 (www.kulturad.org/images/practise2.pdf), of which this essay is in a way a follow-up, has examined their aims and the courses they offer at some length; a nine-year interval is too short in the life of a university department for major developments that would justify a brand new report that would not be repetitive. These programs have been followed since by the addition of a graduate component of Sabanc1's undergraduate program, and the opening of another graduate program at Şehir University, to both of which I devote more space.

\section{Istanbul Bilgi University}

The privately-owned Bilgi University (established in 1996) ${ }^{12}$ opened an MA program in cultural studies. The medium of education of this university is English, but the program is announced as "bilingual" on its website (see "Program Structure" at "Istanbul Bilgi University MA in Cultural Studies"). It is the only cultural studies program to be avowedly so, a trait that distinguishes it from the other cultural studies programs in the country. It features among its faculty Kevin Robins from the U.K., and Turkish intellectuals such as Murat Belge and Mete Tunçay, and the Armenian of Turkey Arus Yumul, as well as Ferda Keskin, organizer of the 2006 Crossroads conference in Istanbul and later chairman of the Association for Cultural Studies (ACS) from 2008 to 2012. It is being "coordinated" in succession by members of its teaching staff.

Among the courses offered (besides the basics), "Religion, Culture and Globalization" surveys "the historical and social landscape of religion in Turkey" and is recommended for international students. "Politics and Biography," conducted in Turkish, is "designed to develop [an] in-depth understanding of the process of social and political change by studying memoirs in Turkish." Strangely enough, "Political Philosophy," a course analyzing "major concepts of political philosophy in the period between ancient Greece and the mid-nineteenth century," with texts from "Aristotle, Aquinas, Spinoza, Hegel, and Marx" is also given in Turkish. ${ }^{13}$

\section{Crossroads Conference}

One of the achievement s of Bilgi University has been the organization of the "Crossroads in Cultural Studies" conference in 2006. With a reported participation of 600, and a world-renowned keynote speaker, Partha Chatterjee, it was a highly successful conference, as good as any international conference organized by top establishments anywhere in the world. As mentioned above, ACS then elected its organizer, Keskin, to head the association. The wrap-up session was memorable for a heated discussion on the use of English in cultural studies. 


\section{Cultural Studies Journal}

The program started publishing a cultural studies journal in 2011, the only one of its kind in Turkey at present. However, the bilingual (Turkish-English) KÜLT appears at present more of a review than a purely scholarly journal, and moreover seems to have halted publication at the end of 2011 after one inaugural issue in June devoted to "canon" and one double issue in November devoted to "culture." No other issue is mentioned on its website (see KÜLT Kültürel Incelemeler Dergisi).

\section{Boğaziçi University}

The Department of Western Languages and Literatures at Boğaziçi (Bosphorus) University, a state university also with the medium of education in English, ${ }^{14}$ opened an MA program in Critical and Cultural Studies (see the "Boğaziçi University Graduate Program in Critical and Cultural Studies"). The teaching staff of the program is made up of the department faculty. The program has been chaired since its inception by Işıl Baş, an Anglicist, and member of the department faculty.

Besides compulsory basic courses, "[s]tudents whose undergraduate degrees are not in English Literature are required to take at least one elective course from the English Literature pool." The other electives may be taken from the other departments of this 150-year old university offering a wide range of courses on both Western and Turkish/Ottoman cultures, but the set-back is that these courses may not, as a matter of course, have been designed from a cultural studies approach.

\section{Sabancı University}

A undergraduate program was opened simultaneously at Sabanc1 University (also established in 1996), whose medium of education is also English. Its faculty features the American Annedith Schneider who penned her initial experiences in an essay published in 2002 entitled "The Institutional Revolutionary Major? Questions and Contradictions on the Way to Designing a Cultural Studies Program in a New Turkish University" (for another look at cultural studies in Turkey by yet another "expat," see Raw 2004). The program is within the university's Faculty of Arts and Social Sciences (FASS), and is chaired by members of its teaching staff on a rotating basis. As the website of that faculty indicates, it is "[d]epartmentfree by design" and "an interdisciplinary home to degree programs that range from visual arts and visual communication design to cultural studies, social and political studies through conflict analysis and resolution, economics and history" (see "Welcome to FASS"). In other words, the students enrolled in this faculty do not major in any particular discipline, they receive a diploma in "arts and social sciences" at the end of four years. 


\section{Graduate Program}

The Sabanc1 cultural studies program then started in 2006 an MA program with "thesis" and "non-thesis" options, ${ }^{15}$ presented thus on the university's website:

The Cultural Studies Program brings together an interdisciplinary group of scholars with a commitment to fostering new ways of analyzing and participating in contemporary cultural dynamics in Turkey and around the world.

The program covers a wide range of topics and theoretical approaches, with particular emphasis on: literary and cultural theory; gender and sexuality, transnational mobility and migration; ethnic identities and citizenship; politics of representation; memory studies and oral history. ("Sabanc1 University Faculty of Arts and Social Sciences Cultural Studies”)

Of the courses offered may be seen, beside the basic ones, such courses as "Modernism/Postmodernism," and "Cultures of Migration," showing an emphasis on the "around the world." In another course entitled "Gendered Memories of War and Political Violence," which "explores the different ways in which war and political violence are remembered through a gender lens," Turkey is in dubious company alongside Argentina, Germany, Hungary, Rwanda, and the former Yugoslavia. The only course that is devoted to Turkish culture is "Thematic Approaches to Contemporary Turkish Culture," which is presented in this way: "Based on readings of urban space as well as analyses of visual and written texts, this course will trace and map current cultural dynamics and ambivalences of contemporary Turkey ... emphasizing the ways in which politics and culture are articulated in present-day Turkey." 16 The European reader may be interested in "Anthropology of Europe," whose content is announced thus:

\footnotetext{
Anthropology is conventionally perceived as the study of non-European societies, however, recent critical approaches have stressed the importance of turning the anthropological gaze to western societies, and in particular, of "provincializing Europe." ... [T] he course will examine historical and contemporary constructions of "Europeanness"; debates over multiculturalism, cultural citizenship and "Islamaphobia"; migration and ethnicity; and the uneasy relation of Eastern Europe and postsocialism to Western Europe an the EU. ("Graduate Courses - Sabanc1 University Faculty of Arts and Social Sciences Cultural Studies")
}

The titles of the MA theses submitted during the time frame 2008-2012, also listed on the website ("Theses - Sabanc1 University Faculty of Arts and Social Sciences Cultural Studies"), ${ }^{17}$ show a great diversity in both theme and line of approach, and give a good idea of the direction and scope of the program. ${ }^{18}$

\section{Middle East Technical University}

An MS program in Media and Cultural Studies was opened in the fall of 2002 at Middle East Technical University (METU - Orta Doğu Teknik Üniversitesi [ODTÜ] in Turkish), also a state university whose medium of education is English. The program has been chaired from its inception by Raşit Kaya, a professor of political science who obtained his doctoral degree from the "Institut Français 
de Presse en Science de l'Information" of Paris University. The teaching staff includes practising journalists with doctoral degrees such as Uluç Gürkan and Doğan Tiliç. The scope of the program is narrower as it focuses on various aspects of the media, and it offers MS degrees with and without thesis. Thus, alongside courses such as "Ethical Issues in Journalism" or "Mass Media Discourse from [an] Ethnocultural Perspective" (besides of course the "basics"), it offers "practical" courses such as "Introduction to Video Production" ("Courses - M.S. Program in Media and Cultural Studies [thesis and non-thesis]"). The only course pertaining to Turkish culture is the "Issues in Turkish Cultural History: Popular Culture, Power, and Subalternity," a "core course," which traces "the historical formation and transformation of Turkish popular culture," with "[p]articular emphasis ... on the distinction and relation between the official-high culture and the folk-popular culture ..." ${ }^{\prime 19}$ Its long reading list contains works in both English and Turkish ("ADM 5117 Issues in Turkish Cultural History: Popular Culture, Power, and Subalternity"). However, "students can take any relevant graduate course offered by other departments upon the consent of the advisor" ("Courses - M.S. Program in Media and Cultural Studies [thesis and non-thesis]"). To approve of courses designed from a cultural studies approach seems here to be the responsibility of the advisor.

\section{Istanbul Şehir University}

The Istanbul Şehir (City) University, yet again an English-medium establishment, was opened in 2008 by a foundation (Bilim ve Sanat Vakfi - The Knowledge and Art Foundation).$^{20}$ It started accepting its first students in the academic year 20102011. It has opened a graduate program in cultural studies, chaired by Mahmut Mutman, a professor of communication studies, and has collected scholars, among them Ferhat Kentel and Mesut Yeğen, professors of sociology known for their pro-Kurdish stance, as well as promising young Ottomanists. Under the heading "Cultural Studies at Istanbul Şehir University: Approach and Philosophy," the program is described as being "an interdisciplinary program established with the contributions of various departments and faculty ... offer[ing] a rich variety of courses that covers all major areas of research in cultural studies and teaches its most well-known theories and methods ... for studying various aspects of cultural life."... It ... puts a special emphasis on cultural plurality as [an] essential aspect of cultural life." The website also notes that the program has "two major areas of special emphasis"; namely:

1. Critical analysis of the increasingly industrialized, commercialized and spectacular contemporary cultural scene; theories, methods and debates in this field; cultural texts, meanings, identities and differences; hegemony and resistance; globality and locality. 
2. Modern Ottoman-Turkish cultural history, especially a critical and analytic grasp of Turkish cultural modernity; Orientalism and Westernism; nation-state, political culture and social and ideological movements; a dynamic and pluralist approach to various modern cultural histories of literature, cinema, music, visual arts, media, popular culture, religion, ethnicity and everyday life. ("Cultural Studies: What does it Study and How?")

Besides the basic courses, and such "international" courses as "Gender Theory" and "Globality, Culture and Identity," the program offers many courses focused on Turkish as well as Ottoman culture: "Istanbul in Ottoman Texts," "Comparative Analysis of the $19^{\text {th }}$ Century Armenian and Turkish Literatures," "Modern Ottoman-Turkish Literary and Cultural History," "Aesthetics and Gender in Ottoman Culture," "Crises of Masculinity and the 20 $0^{\text {th }}$ Century Novel," "Empire, Colonialism and Orientalism in Modern Turkish Literature," "Identity, Culture and Ethnicity in Turkey," "Late Ottoman Intellectual History," "Narrative and Narrativity in the Ottoman Empire," "Religion and Politics in Turkey," and "Mass Media and Power in Turkey." Especially noteworthy is the course "Modern Turkish Political Thought," which discusses thinkers of the right, from the late Ottoman era up to the current period, usually ignored or categorically disregarded by leftist-oriented academics and intellectuals. ${ }^{21}$

Among the programs, this one appears to be the most geared to the local scene without neglecting the prevalent (international/Western) "theories, methods and debates in this field," though of course one must wait to see how it fares over time.

"As this essay is being written (June 2003), none of the ... programs have produced any graduates. ... So any evaluation of these programs is premature," Pultar and Kırtunç wrote (Pultar \& Kırtunç 2004). Today, this can be relevant for the Şehir program only; sad to say, the four programs established earlier, including the Sabanc1 graduate program that appears to have been the most productive, have yet to make an impact nationwide. Perhaps one needs to wait for the opening of doctoral programs and their output for these cultural studies programs to acquire clout outside of the confines of the English-medium academia in the country. ${ }^{22}$

\section{Problems Facing Cultural Studies in Turkey}

With an active association regularly organizing biannual conferences and more; a(n other) biannual conference already become traditional organized by a major state university; graduate programs at four universities churning out each year new would-be scholars in the field, another newly-opened graduate program that has started instruction, and a journal devoted to the field that has been launched (whatever its ultimate fate is to be), cultural studies in Turkey appears to be "all 
set," as the American colloquialism has it. In fact, the truth is far different, and cultural studies in Turkey is facing a number of problems that are summarized below.

Of course, cultural studies is currently faced with problems everywhere it is taught and practiced, as was quite apparent from the many papers from European scholars at the June 2011 ACSIS conference in Norrköping. I try below to highlight those that are particular to Turkey, that arise from the characteristics of Turkish society. As will be seen, some of these problems are intertwined. Some are important, some are less so (and may even be considered purely formalistic, while some may be seen as afflicting social sciences and the humanities in general), but together they hinder the development of a much-needed perspective that only cultural studies can provide. I list seven which I believe need to be debated upon, even if no solution is found for them in the short term. These may be termed briefly as the lack of any "chair" in cultural studies, confusion in the terminology, the perception of the objective of cultural studies as "frightening," the mis/use of "culture" as a term, the language divide, the Turkish predicament of being both the hegemon and the subaltern, and the abundance of material.

1. The lack of any "chair" in cultural studies. Although five universities carrying weight in different ways in Turkish academia have opened the said programs, there is at present no "chair" in cultural studies. Academic promotion in Turkey runs thus: universities hire Ph.D.s and will confer on them the title of "assistant professor" at their own discretion. However, to become an "associate professor" (doçent in Turkish, from the German Dozent) a Ph.D., whether employed or not, is required to pass a state examination after a certain period of time following the reception of his/her doctoral degree. ${ }^{23}$ "Cultural studies" does not figure among the disciplines in which this examination may be entered. Governed by rigid hierarchization and departmentalization, Turkish academia is wary of theoretical hybridity, and refuses to acknowledge work that is cross/trans/interdisciplinary. Those teaching cultural studies courses, whether in the abovementioned departments/programs or in other departments/programs, pursue their formal careers in those disciplines that are recognized (i. e. sociology, anthropology, literatures in different languages, etc.). They would have adopted the cultural turn / acquired a cultural studies approach during the course of this career; nevertheless it is the demands of that career that take precedence at all times. Cultural studies is either neglected or altogether abandoned. A case in point is the example of the above-mentioned Raw who was one of the first ever instructors in cultural studies in Turkey: by his own confession, he turned to film studies and adaptation studies when the British Council 
ended its cultural studies courses (e-mail message to author, $26 \mathrm{Au}$ gust 2011). ${ }^{24}$

2. Confusion in the terminology. There is moreover the issue of terminology: "cultural studies" is translated into Turkish in various ways. From the beginning KAD adopted kültür araştırmalarl, a noun phrase formed according to long-established Turkish language rules; the five universities employ the adjective kültürel where the suffix -el is for Geoffrey Lewis (1920-2008) an imitation of the French culturel (2009: 124) which apparently sounds more "Western." For studies, in opposition to KAD's araştırmalar(l), Sabancı, Boğaziçi, METU and Şehir employ çalışmalar, while Bilgi uses incelemeler. These words all mean "studies" and are alternately used at all times, with, however, araştırmalar first of all meaning researches, çalışmalar first of all meaning works, and incelemeler first of all meaning examinations. ${ }^{25}$ This situation creates a cacophony of a sort, as no one central fulcrum can be established. Boğaziçi University and METU each offer degrees in one aspect of cultural studies, and the other four (KAD and Bilgi, Sabancı and Şehir universities) are apparently doing different things, neither one wishing to seem to defer to any of the other(s).

3. The "frightening" objective of cultural studies. On a more intricate level, it is the objective proper of cultural studies which frightens laymen and officials alike. As is known, just like with women's studies, the aim of the discipline of cultural studies is not merely to do scholarship but to reach the community, as cultural studies also inheres political criticism and activism. In other words, the work done should ideally be directed towards a political project, towards an improvement of the power relations that are taken up, questioned and more often than not decried. The "overt political engagement" of cultural studies (Schneider 2002), is near to impossible in Turkey, as such a stance is immediately seized upon as anarchism or extremism. Academics in Turkey have generally been "expected to stay out of politics," as Schneider puts it, or else leave academia to pursue directly a political career.

4. The mis/use of "culture" as a term. There are also problems with deeper ramifications. One has to do with the term culture itself. The word is disquieting because ideologues of various hues in the country have been and still are presenting as "culture" much material that is purely political. Consequently, the man in the street tends to consider the concept of culture as heralding subversive agendas, of being a veiled synonym e.g. for separatism, or for some other obnoxious topic. The layman's attitude finds itself reflected in gatekeepers' be- 
havior when e.g. allocating funds, deciding on the publication of texts or allowing for the organization of conferences.

The association (KAD) is faced with additional problems. Ever since the military regime instaured after the September 12, 1980 coup closed down all associations, declaring them breeding grounds for terrorism and thus "harmful" to society, the average citizen has been steering clear of all of them. New ones were later allowed to be established, and today, in 2012, there are over 85000 associations (derneks) in the country according to the information given by the Ministry of Interior Affairs ("Türkiye'de Dernek Sayısı 85 bin'i Buldu" [The Number of Associations Has Reached 85 thousand]), but career-oriented academics have been sharing the sensitivity of the man in the street, and, unless it directly profits their advancement, ${ }^{26}$ shying away if they can help it from any involvement with organizations. The AKP regime, which has imprisoned during its decade in power a horrifyingly vast number of authors, journalists, scholars, and intellectuals for having criticized it, has accused each one of them with having "ganged up" with would-be coup makers. This attitude of the government, especially its interpretation of "gangs", has only served to exacerbate the already existent phobia concerning involvement with organizations. $^{27}$

5. The language divide. Cultural studies in Turkey is characterized by a phenomenon: there is a pronounced "divorce" between "Anglophone" Turkish scholars and "merely Turcophone" ones. Westerneducated Turkish scholars teaching (cultural studies or any other West-based discipline) in English-language media universities mostly dwell in a world of their own, and have no time or interest in anything published in their subjects of specialization in Turkish, especially as some of these publications lack a theoretical framework and are "wanting" in APA or MLA rules. ${ }^{28}$ The disdain appears reciprocal, as scholars whose professional formation is basically turcology (which embodies various branches of Turkish studies), and who publish in Turkish only, tend to consider the authors of publications in English, whose formation is usually not related to Turkish studies, mostly illequipped to tackle such subjects. They consider moreover the publications themselves, when they are able to read them, as more often than not demonizing Turks and Turkey. ${ }^{29}$ As long as there is this rift, which perhaps for some is as much a divide in academic background and ideological commitment as it is linguistic, cultural studies in Turkey cannot develop adequately. I believe this is the most important hurdle cultural studies of Turkey needs to overcome. 
My experience while teaching at METU, Bilkent, Boğaziçi and Bahçeşehir universities (all of them English-medium) respectively, between 1982 and 2012, has time and again shown me that the "Anglophones" will mostly look down on work done in Turkish, as they look down on Turkish codes of dress or behavior that are alien to the Western Weltanschauung with which they are imbued ${ }^{30}$ but also because the texts are uninformed of the theories of Western luminaries. But even more importantly, because the work in Turkish (whatever its intrinsic merit) has not received the stamp of approval, the recognition and legitimization of the West. By extrapolation, any cultural studies work written in Turkish is vested with the same stigma - and ignored, or downplayed as negligible. There is the danger, however, that the stigma attached to work done in Turkish and published in Turkey may eventually act as a deterrent to original cultural studies work that is in its infancy but has the potential to engender novel theories pertinent to the Turkish situation.

It is only work that has obtained its titre de noblesse by being published in English, in the West, which acquires validity in Turkey, for example in a Turkish translation, which is then regarded much more highly than any original publication in the Turkish language; although, to be "palatable" to the Western publisher, the text probably had to be adjusted, and is not any more part of the Turkish narrative, or is a mere one-sided view of it. For example one can easily get published in the West writing about Turks oppressing Kurds but one wouldn't easily get published writing about Kurds in Northern Iraq oppressing the Turks in the region, the Turkmens.

6. One issue that is not given due importance is the Turkish predicament of being both the hegemon and the subaltern. Depending on their political stance, scholars will adopt either one or the other view, but that is seldom the whole picture, so something is always missing, and the work ends up being not totally satisfactory. For example, had the Turkish parliament not vetoed it, what would have the Turkish army's entry into Iraq in March 2003 signified? Turks' return to the land that was theirs for over five centuries which the British unscrupulously accaparated from them during World War I, or, as the Bush administration expected, their attending to the US army as minions?

Those Turkish scholars writing in English see Turkey as a Third World country and treat its society as such in their studies - and/or, additionally agree with their Western or Western-oriented colleagues who acknowledge Turks as hegemons only to denigrate them as having been, and in certain instances still being, brutish despots. On the 
other hand, those writing in Turkish start from the premise of the "glorious past" - of not only the six centuries of the Ottoman Empire, but also that of an ethnos that goes as far back as the times of the "Golden Man" of the fourth century BC, ${ }^{31}$ if not much earlier. ${ }^{32}$ Both attitudes may be justified in different cases, but the existing dichotomy is detrimental to the development of cultural studies in Turkey. Because of the confusion it generates, a master paradigm cannot be developed.

7. The abundance of material. As cultural studies as a matter of principle sets no boundaries, the tacit understanding is that any scholar (provided s/he is academically adequately "equipped") can do cultural studies work on any topic. The cultural studies scholar, whether a Turk or a foreigner, who would like to do work on any topic related to Turks and Turkey finds him/herself confronted with an abundance of material. This state of affairs stems from four main factors of divergent nature: there is still a lot of "catching up" to do; there is still a lot of untapped material; the population of Turkey includes very many ethnic groups; and there are very many peoples who are Turks. While this wealth offers a myriad of opportunities, it also seems at times to act as deterrent. The first two tend to hinder with their call for immediacy, and the last two bewilder almost with their multitude.

First of all, Turkey, a latecomer to industrialization, has still got catching up to do in many areas, including scholarship, long before the questioning stance of cultural studies can be brought in. Just to give an example, one cannot start work on criticizing museums (questioning their particular display of material, etc. and the motives behind that selection) when studies on how museums should be organized have not been fully developed first. This is so in many fields.

Secondly, there is a lot of material that has remained untapped that needs to be seen to - descriptively, to start with. So, many scholars who could be doing cultural studies are led to and distracted by this body that needs to be handled initially in a traditional manner. For example, Ottoman-bashing - started in the nineteenth century with Western powers calling the Ottoman Empire "the sick man of Europe," a labeling the founders of its successor state, the Republic of Turkey, espoused in order to justify then consolidate their endeavor continued for a very long time, and it is only in the last quarter of the twentieth century that the Ottoman era has started to attract genuine interest and be examined dispassionately. ${ }^{33}$

Parenthetically, perhaps such a "moratorium" is normal after the demise of any empire, but this particular one had a lot to do with the 
brainwashing the generations of Western-educated Turks underwent. In a way, for those Turks who were adults in the 1990s and beyond, it was most salutary, if I may so put it, to see the Saddam-bashing of the 1990s (culminating with the acts committed during the war in Iraq that started in 2003), and the Kaddafi-bashing of the 2010s: they were able to see for themselves how Western (neo-)imperialism works and visualize how Ottoman-bashing must have taken place. (I have of course in mind the Western-educated Turkish intellectuals abreast of the development of historiography in the West; classical Turkish historywriting glorifying the "Sultanate," with perhaps even an antirepublican undercurrent, has always existed.) It must be said that in this respect a formidable task, and a cultural studies one at that, awaits the scholar of Ottoman studies and of Turkish studies in general, whether s/he be a Turk or not: as William du Bois (1868-1963) pointed to the double-consciousness of the Black in the United States, so must the scholar of Ottoman and/or Turkish studies, alongside pursuing his/her own travails, muster such a double-consciousness in order to revisit and if necessary revise the clichéd image of the Turk in Western and Western-influenced discourse.

Thirdly, the abundance of material stems also from the fact that the Ottoman State was a poly-cultural society. The residue is still to be found within the confines of Turkey. Albanians, Arabs, Armenians, Bosnians, Bulgars, Circassians, Georgians, Greeks, Kurds, Jews, Laz, Pomaks, Roma, Syriacs, Zazas are only some of the ethnic groups which compose the population of Turkey besides the ethnic Turks. The latter themselves are more composite than may be imagined at first: there are not only the descendants of the Ottoman Turks, whose generations have been native to the land for more than seven centuries now, but also those Turks from other lands: not only those who "stayed behind" in the former territories of the Ottoman Empire in the Balkans and the Middle East, but also the Crimean Turks (also known as Crimean Tatars), the Kazanlis (also known as Volga Tatars), the Azeris (of both Iran and Azerbaijan), the Kazakhs, the Kirghiz, the Turkmens, and the like - those whom the English language distinguishes as Turkic as opposed to Turkish but who share the same cultural heritage. Many of these migrated to Turkey in or after 1917 if not before.

It is a fact also - and that is the fourth element constituting the abundance of material - that the demise of the Soviet Union at the end of 1991 has brought to the fore the cultural and ethnic ties that bind the Turkic peoples, as they are thus labeled, and the Turks of Turkey, in- 
troducing at once compelling issues of nation-building and renegotiation of identity. Azerbaijan in the Caucasus; and Kazakhstan, Kirghyzstan, Turkmenistan, and Uzbekistan in Central Asia, made nominal republics by the Soviet regime, are now independent nation-states. Turks of Turkey share a common culture with them: the mythology, epics and classical works of literature are common, and so is a history going back to ancient times. The present cultural tribulations of these "new" nation-states, zigzagging between a post-Soviet rejection of Russian culture, the still "dominant" culture as Raymond Williams would put it, and a just as poignant retention of it, and the simultaneous hesitant return to and re-espousal of Turco-Muslim culture, that is just as emergent as it is even more residual, perforce fall within the area of interest of Turkish cultural studies.

\section{Conclusion}

Cultural studies started in Turkey in the 1990s as a soft colonial project on the part of the UK couched as British Council activities. It was utilized in turn by the USA operating through its USIS office (since then become the office of the Cultural Counsellor of the US Embassy), especially through the annual American studies conferences it organized in "collaboration" with ASAT (whose foundation it had instigated), not only as a function of its propaganda machine, but also for its ulterior motives: the writer of these lines remembers many an American studies conference wrap-up session during the 1990s where suddenly the "Kurdish issue" flared up, seemingly out of nowhere, without even the aid of "transitional" terms indicating a comparison could be made with such and such American issue. (With the demise of the Soviet Union, the attention proferred on Turkish scholars waned almost abruptly in favor of "East European" and other post-Soviet colleagues, and Turkish Anglicists and Americanists, feeling left stranded, now reminisce on the largesse and consideration they used to receive in different ways from the British Council and the USIS.)

Reclaimed soon enough by Turkish scholars themselves, cultural studies developed over the years in Turkey, but encounters today a number of problems it needs to cope with if it is to develop further. Humanities and social sciences have been undervalued for long in a society that is trying to catch up on the Industrial Revolution. So, an offshoot such as cultural studies naturally also possesses a low status. Grants and funds easily available for "science" subjects are inexistent for humanities and social sciences, and consequently for cultural studies. However, the case of cultural studies presents a graver matter. Whether cultural studies is and should remain merely an approach or whether it is and should be a fullfledged academic discipline is an ongoing debate even in those Western centers where it first saw the light. Be that as it may, it is a fact that in Turkey an academ- 
ic cannot pursue a career in cultural studies. Attracted at first by the intellectual challenge it offers, many bright young men and women soon seek fame and glory elsewhere, and they cannot be blamed. Turkish society rests on power, not achievement, and pays great importance to hierarchy and titles. The Ottomans, from whom evolved present Turkish society never instituted hereditary titles; titles - of whatever character - need to be earned, and quickly, during one's own lifetime. Thus all academics doing what would be defined as cultural studies make sure their work also suits the (mostly rigid) requirements of other, well-defined disciplines - which is more often than not the loss of cultural studies. As Schneider points out, even students themselves "show little inclination to take a course of study that, to their eyes, does not lead to a career" (2002).

Moreover, cultural studies in Turkey possesses a heterogeneous character. One reason seems to be that it seems to follow a two-track path, as an apparently insurmountable rift exists between those practitioners of it doing academic work in English, and those doing academic work in Turkish. The two "sectors" are to a great extent non-cognizant of each other's work, so there is no adding up, no accumulation of scholarship. KAD was born out of the necessity of doing cultural studies in one's mother tongue, of examining everyday life in the everyday language of Turkey, ${ }^{34}$ and of coining terms that were until then inexistent. Yet those academics teaching in English-medium universities have been shunning it for the very same reason. ${ }^{35}$ Turkish seems the "vulgar" language as opposed to their "Latin." Also, because their abstraction has been in English, they find it bothersome to have to translate or to coin new terms. Furthermore, those teaching in English-medium universities need to continue to do work i. e. to publish in English, as in order to be promoted in their universities they need to be figured in journals indexed in the United States. ${ }^{36}$ Which automatically prevents any accumulation of knowledge and scholarship in cultural studies in Turkey. ${ }^{37}$ This covert neo-colonization of the Western-educated mind is overlooked in the current discourse on globalization, and the implementation of such projects as the Erasmus program which assumes that all instruction under the sun may somehow be conducted in English. ${ }^{38}$

One practical result is that those scholars who may not know English never have the benefit of the scholarship in English on their subjects, thus never become truly cognizant of the "cultural turn" and continue their production of theory-free work $^{39}$ - for which there is more than abundant untapped material, as mentioned above. Yet the bulk of material that is the subject matter of potential cultural studies work is in their possession, so to speak. Most Western-educated academics teaching cultural studies in the English-medium universities where such programs exist are not graduates of Turkish history or literature or related subjects (as may be easily seen from a survey of the faculty lists of the programs I discussed above). ${ }^{40}$ They only bring the method, and the theoretical framework serving as basis for their work. But again, this framework is founded on Western theoreti- 
cians' ideas, and what they propound is not always relevant to the Turkish situation (see Pultar 2005 for a treatment of this and related issues). ${ }^{41}$ So somehow the material and the methodology cannot be brought together and no novel formulation, no new theorization is able to emerge from cultural studies in the country. ${ }^{42}$

Yet a more important point is that these ideas do not emanate from within. There is as yet no cultural studies textbook in Turkish, nor perhaps is there any need for one. The five universities where it would/could be used as a regular student textbook are all English-medium universities which stress the interdisciplinay nature of cultural studies and the need for the students to acquire a critical, questioning stance. When one surveys their curricula, one sees that their main concern is, as Pultar and Kurtunç indicated, "training the students in the theories of the major figures of Anglo-centric cultural studies (with that of the ubiquitous French as part of its corpus) to allow them to 'perform,' namely, do research, teach, participate in the international academic arena, as masterfully as all other international scholars" (Pultar \& Kırtunç 2004), rather than having as their primary aim forging Turkish cultural studies / cultural studies of Turkey. One cannot but sense in this stance a whiff of neo-colonization - in which all of us Westeducated non-Western intellectuals find ourselves in, whether we like it or not, or are aware of it or not - that translates in action into unconscious neo-colonialism.

Yet as one does work in cultural studies in Turkey, one realizes how imperative it is to generate new, original theory and methodology. What emerges in the West does not address the same issues and predicaments: Turkish society is not as "industrialized" as Western societies; so, statistically speaking, media and the culture industry have not reached the proportions at which Western theory would bring elucidation. Post-colonial theory, broadly speaking developed mainly by non-Western scholars from former British and other European colonies or ethnics within the United States, constitutes too much of a response to Anglo-Euro hegemony to address Turkish society's Janus-faced position of being both a hegemon itself and a victim of Anglo-Euro neo-imperialism.

In the meantime Turkish society is changing fast. It is changing fast in the twenty-first century and requires analysts and theoreticians to make sense of the transformation, at a time when, it may be argued, the radical alterations brought about by the Kemalist revolution and the establishment of the Republic in the twentieth century have not yet been sufficiently analyzed and put into perspective. The necessity of shedding long-standing familiar stances, however cozy these may be, of moving beyond titles and labels, and doing substantial cultural studies in Turkey remains an acute issue. 
Gönül Pultar is the founding president of the Cultural Studies Association of Turkey. She has taught at Bilkent University and METU, and was a fellow at Harvard University. She has held various positions at ASA, IASA, MLA, and MESEA, and was the Vice-president of ASAT. Her area of specialization is the twentieth-century Western novel, especially the American ethnic novel. She was the founding editor of Journal of American Studies of Turkey. Her published works, in both English and Turkish, include, besides many essays, the monograph Technique and Tradition in Samuel Beckett's Trilogy of Novels (1996); and various collections of essays, among them On the Road to Baghdad or Traveling Biculturalism: Theorizing a Bicultural Approach to Contemporary World Fiction (2005), and Imagined Identities: Identity Formation in the Age of Globalization (fall 2013). She is also the author of the short story "Leda and the Swan" (2001), and of two novels in Turkish. E-mail: gpultar@kulturad.org

\section{Notes}

1. One of the students, Derviş Zaimağaoğlu, received one of these and completed his MA degree in Warwick (Raw, e-mail message to author, 26 August 2011). Cyprus-born Boğaziçi University graduate Zaimağaoğlu would go on to become, as "Derviş Zaim," a well-known director, with such award-winning feature films as Tabutta Rövaşata (Somersault in a Coffin, 1996), Filler ve Çimen (Elephants and Grass, 2000) and Gölgeler ve Suretler (Shadows and Faces, 2010). He would also co-direct with Greek Cypriot Panicos Chrysantou the documentary Parallel Trips (2004) "in which the two directors, from opposite sides of the divided island of Cyprus, recorded the human dramas that unfolded during the war of 1974 and the legacy that remains today" ("Derviş Zaim"). For an interview Raw conducted with his former student, see in his Exploring Turkish Cultures (2011) the chapter entitled "Derviş Zaim: 'To Return to the Past Means Embarking on a New Journey'."

2. This is what American studies is formally called in Turkey.

3. Raw remarks that the English language "Teaching Centre" in Istanbul "was closed three years later, as the Turkish government objected to a British Embassy-sponsored organization challenging their language schools. Since then the Council has done absolutely nothing to promote British interests, while Cult Studs has lost a lot of its edge within UK, especially after the closing of the Birmingham Centre \& the Warwick Centre" (e-mail message to the author, 26 August 2011).

4. Such a young scholar was Boğaziçi University graduate İrem Balkır (1965-2006) who received a doctoral degree in Cultural and Critical Studies from the University of Pittsburgh in 1993 and joined the Department of American Culture and Literature at Bilkent University in 1994. Balkır was immediately adopted by the American studies community in Ankara, made an ASAT member and elected to its executive committee. She attended and presented many papers at ASA and MELUS conferences in the USA, and also served as Acting Chair of her department from 1997 to 1999 . Yet she was adamant to her dying days of not being an Americanist but a cultural studies scholar.

5. Five scholars, among them the writer of these lines, presented papers on Native Americans and African Americans.

6. It was organized by, besides ASAT and the Ege University Department of American Language and Literature, the Department of English Language and Literature of that university, with the British Council through Raw and the USIS (United States Information Service), as it was called then, through contacts the ASAT presidency had among its officials, 
acting as sponsors, funding the trips to Turkey of keynote speakers from their respective countries.

7. Proceedings volumes to have come out so far are Crossing the Boundaries: Cultural Studies in the UK and US (1997) edited by Raw, Büken and Günseli Sönmez İşçi (then Chair of the Ege University Department of English Language and Literature, and co-organizer of CSS the first few years, now Dean of the Faculty of Science and Letters of Yeni Yüzyıl [New Century] University [Istanbul]); The History of Culture: The Culture of History (1998) edited by Raw, Büken and İşçi; Popular Culture(s) (1999) edited by Büken, Raw and İşçi; Dialogue and Difference (2000) edited by Raw and Kirtunç; New Cultural Perspectives in the New Millennium (2001) edited by Kırtunç, Büken, Raw and Rezzan Silkü (Ege University); Globalization and Transcultural Issues in the New World Order (2001) edited by Remington, with İşçi and Büken as advisory editors; Selves at Home, Selves in Exile: Stories of Emplacement and Displacement (2003) edited by Kırtunç, Atilla Silkü, Kenneth W. Rose and Murat Erdem (the last three Ege University); Inside Outside In: Emotions, Body and Society (2005) edited by İşçi, Dilek Direnç and Züleyha Çetiner Öktem (the last two Ege University); [City in (Culture] in City) (2005) edited by Kırtunç, Eleftheria Arapoglou (Aristotle University [Thessaloniki]) and Erdem; When Away Becomes Home: Cultural Consequences of Migration (2007) edited by İşçi, Direnç and Gülden Hatiboğlu (Ege University); Memory and Nostalgia (2009) edited by A. Silkü, Erdem and Patrick Folk (Ege University); and Proceedings of [the] Thirteenth International Cultural Studies Symposium "Change and Challenge” (2012) edited by Erdem, Lois R. Helmbold (Ege University) and A. Silkü. The first four volumes were published by the British Council; the fifth one (New Cultural Perspectives in the New Millennium) was co-published by ASAT and the two departments involved; and the remaining ones were published by Ege University Press. The titles of the proceedings are also the titles of the symposia.

8. The biannual conferences and their proceedings feature papers in Turkish as well.

9. A type of music generated on the fringes of the mainstream, reflecting the woes of the migrants from rural areas to big cities.

10. Besides the already mentioned Büken (since then retired from Bilkent University), Kırtunç (later editor of JAST for a time, and since then retired from Ege University), Pultar (since then retired from Bilkent University, currently the president of KAD) and Raw (who moved to Başkent University [Ankara] after his job at the British Council was over, and is currently the editor of JAST), there were: professor of sociology Bahattin Akşit (at METU at the time, now at Maltepe University [Istanbul]), Central Asian studies scholar Çiğdem Balım Harding (at Manchester University at the time, now senior lecturer at Indiana University), Mutlu Binark (at Gazi University at the time, now professor of communication studies at Başkent University [both in Ankara]), anthropologist Emine O. İncirlioğlu (at Bilkent University at the time, now professor of sociology at Maltepe University and currently KAD's vicepresident), professor of Turkish literature Talat Halman (Chair of the Turkish Literature department at Bilkent University, and now additionally Dean of the Faculty of Humanities and Letters), professor of English language and literature Himmet Umunç (at Hacettepe University at the time, now Chair of the Department of American Culture and Literature at Başkent University), and professor of architectural history Yıldırım Yavuz (METU). Some of them have then become members of KAD.

11. Bülent Ecevit (1925-2006), the left of center political leader who became prime minister four times between the years 1974 and 2002, represented Zonguldak as an MP for many years.

12. It was founded by Bilgi Eğitim ve Kültür Vakfı (Bilgi [Knowledge] Education and Culture Foundation) established in 1994 for that purpose, but was sold later to the Laureate International Universities Network (founded in 1998, headquartered in Virginia, Maryland, USA). Laureate has since been trying to turn it into a profit-making vocational college shorn of any academic pretense, which means the future of cultural studies may not be too bright at that university. 
13. Also, already mentioned in the Pultar and Kırtunç essay, is the course "Studies in Cultural Diversity I" which aims to "study the multicultural demographic topography of Turkey within a historical, sociological and cultural background. What have the ethnicities that have inhabited this geography experienced throughout history? How did they contribute to the cultural patrimony of Anatolia? What problems have been faced at what points of break?" The participation of guest lecturers and representatives of ethnic groups is planned.

14. Robert College (RC), the first American educational institution operating abroad was opened in Bebek, on a hill overlooking the Bosphorus, in 1863 during the Ottoman era. Along with its "sister" school, the American College for Girls situated on a hill in the neighboring Arnavutköy district, RC (incorporating a secondary school for boys and a school of higher education, at first for boys only but later made co-educational) was allowed to remain functioning after 1923 when the Republic of Turkey was founded. In the 1970s, the American board running RC decided to split it: a co-educational secondary school (Istanbul Amerikan Robert Lisesi) is still functioning on the Arnavutköy campus, but the higher education facilities in Bebek were turned over to the Turkish government who opened there the Boğaziçi University.

15. Ayşe Öncü, the professor of sociology who chaired the program until recently, said she had strived for years to obtain the graduate program as this would mean that the cultural studies program was no more merely servicing the faculty, but was a department in its own right (private conversation with the author on 10 September 2011 at Kadir Has University, during the "Space and Culture" conference).

16 Its reading list may be of significance to the reader interested in cultural studies within the Turkish context: it includes two collections of essays and one guest-edited special issue published in English, namely Rethinking Modernity and National Identity in Turkey (1997) edited by Sibel Bozdoğan and Reşat Kasaba; Fragments of Culture: the Everyday of Modern Turkey (2001), edited by Deniz Kandiyoti and Ayşe Saktanber (a member of the METU cultural studies program faculty); and Relocating the Faultlines: Turkey Beyond the EastWest Divide (2003), a special issue of South Atlantic Quarterly, edited by Sibel Irzik (one of the instructors of the program) and Güven Güzeldere.

17 Starting with the latest submission these include the following:

- Mixed Feelings over an Unprecedented Election: Contestations of Ethnicity within the Suryani-Keldani Community

- Symbolic Boundaries, Imagined Hierarchies: A Case Study of 'Soviet' Female Domestic Workers in Istanbul

- $\quad$ Remembering Armenians in Van, Turkey

- Armenians Living in Turkey and the Assassination of Hrant Dink: Loss, Mourning and Melancholia

- $\quad$ Breaking the Silence, Easing the Pain: Efforts, Challenges, and Hopes of Feminist Organizations in Turkey and India Working with Survivors of Incest

- Between National and Minor Literature in Turkey: Modes of Resistance in the Works of [Kurdish author] Mehmed Uzun and [Armenian author] Mıgırdiç Margosyan

- $\quad$ Elite Perceptions of Self, Nation and Society in Contemporary Turkey

- Exploring the Intersections: Subordination and Resistance among Kurdish Women in Aydinlı, Tuzla

- New Muslim Male Subjectivities: Masculinities in the Hizmet [read Fethullah Gülen] Movement

- $\quad$ Role of the Military in Turkish Politics: [The] Case of the 1980 Military Coup

- $\quad$ Living to the Tell the Tale: Reading [the] 12 September Coup d'État through the Novels Written by Socialist and Nationalist Authors

- $\quad$ State Violence and Human Rights: The European Human Rights Court Cases Submitted Against Turkey on Detention 
- Global Professionals in Turkey: Personal Narratives of Professionals with MBA Degrees

- Working With and Against Stereotypes: Representations of Honor Among Turkish Immigrant Women in a Migrant Association in Berlin

- Censorship in Visual Arts and its Political Implications in Contemporary Turkey: Four Case Studies from 2002-2009

- Violence and Freedom: The Politics of Kurdish Children and Youth in Urban Space

- Mothering the Army, Mothering the State: Being a Soldier's Mother in Turkey

- The Politics of Women's Empowerment: The Transformative Struggles of KAMER and MOR ÇATI Against Violence

- Manifestations of Gendercidal [adjectival form of a neologism meaning "the genocide of a gender"] Trauma in the Short Stories of Kirkor Ceyhan

- The Meaning of Discovery:Tourist Gaze and Tourist Narratives in Southeastern Anatolia

- Forms of Relation: The Western Literary Canon and Orhan Pamuk's The Black Book [and] Salman Rushdie's Midnight's Children

- The Stomachache of [the] Turkish Woman: Virginity, Premarital Sex and Responses to Ongoing Vigilance Over Women's Bodies

- The Role of Memory in the Historiography of Hatay. ("Theses - Sabancı University Faculty of Arts and Social Sciences Cultural Studies")

18 They appear to reflect an almost defiant attitude that does not stop at critiquing received wisdom and ongoing trends, but goes further to openly confront the Republican Establishment.

19 From the "Course Description": "Particular emphasis will be put on the distinction and relation between the official-high culture and the folk-popular culture, the formation of cultural distinctions and hierarchies, popular representations of the state, subalternity vis-à-vis power, and the questions of legitimacy and cultural hegemony". Among the topics to be explored are "folk religion" and heterodoxy, Turkish shadow theatre, folktales and folk stories, coffeehouses, modern discourses on "the people" and popular culture, cultural politics of Kemalism, popular music and the arabesk debate, football, and popular cinema.

20 This foundation has been established by the Ülker company, known for its ties to the JDP government.

21 "This course aims to discuss the main political issues and schools of modern Turkish political life with special reference to the ideas of leading Turkish intellectuals. The late Ottoman intellectual life will be examined on the basis of main currents of thought: Young Ottomans, liberalism, Turkism, Islamism and socialism. First, it focuses on the various forms of Kemalism; Kadro journal, Yön Movement and its rightist versions. Secondly, it explores the different representations of Turkism in the ideas of Yusuf Akçura, Nihal Atsı, Remzi Oğuz Arık, [and] Erol Güngör in the Republican period. While examining the conservative political thought, it puts an emphasis on the ideas of Yahya Kemal, Mustafa Şekip Tunç, Peyami Safa, Mümtaz Turhan, Ali Fuad Başgil, İsmail Hakkı Baltacıoğlu and journals like Dergah and Hareket. Thirdly, different manifestations of Islamist political thought will be explored with reference to the writings of Necip Fazıl Kısakürek, Nurettin Topçu, Sezai Karakoç, Ali Bulaç and İsmet Özel. This course also deals with liberal intellectuals and circles: Ahmet Ağaoğlu, Kazım Berzeg, and Liberal Düşünce Topluluğu. Lastly, this course turns its focus on the leftist intellectuals, Kemal Tahir, Mehmet Ali Aybar, İdris Küçükömer and Birikim journal” ("Cultural Studies Course Descriptions").

22 I have deliberately refrained from making comparisons and/or evaluating the programs, as firstly, the trends they exhibit are not substantially divergent as to be able to differentiate and delineate major, singular traits, whether in curricula, theoretical and practical tendencies, or degrees of commitment to the field, other than those I have indicated. On their websites they all seem to be using the same vocabulary, those buzz words intended to demonstrate how 
cutting-edge they are, how on par with all other cultural studies programs of caliber in the world. This makes their descriptions of their aims almost generic, although they themselves may not have intended it that way. Secondly, the oldest of the programs is barely a little over a decade old, which is a period of time too short for any fair evaluation of an academic program. In other words, these programs are still in the budding stage, busy building a core curriculum in the basics of cultural studies, an arduous task as the subject matter of cultural studies does not have precisely delimited boundaries. It is too early to criticize them for their lacunae. For example, although more than twenty years have passed since the fall of the Soviet Union, none of the programs seems to have given much thought or spent any efforts working on the newly-independent Turks (or on the not independent ones, as in the case of those within the Russian Federation).

23 The period depends on the legislation of the time.

24 However, his publishing recently Exploring Turkish Cultures (2011), a collection of his essays on various facets of Turkish culture, shows he has retained interest.

25 Established in the early 1980s, ASAT is called in Turkish "Amerikan Etüdleri Derneği" where etüdler (a Turkish word derived from the French études) is employed for studies. It is interesting to note that the sensitivity developed since then concerning language has been such that the blatantly foreign sounding etüdler, which would have prevented any terminological confusion, is out of consideration for all parties concerned.

26 The September 12 regime also promulgated a law governing academic life (called "Yüksek Öğretim Kanunu" [Higher Education Law] - YÖK). Acting according to its precepts, most universities have adopted a method of promotion based on a credit system that attributes "points" to the work done: e.g., authorship of an article published in a citation-indexed journal in the United States will earn more points than, say, participation in a local seminar, however cutting-edge the latter may be. The "worth" in "points" of work done in an association, even a scholarly one, is nil. What's more, as Turkish society rests not on achievement but power, as will be pointed out in the Conclusion, collective work, because it is not conducive to individual distinction, can never be widespread; so team work, characteristic of associations, is next to impossible in many instances.

27 Needless to add that this is a far cry from the state of affairs in Europe and the United States where such work is encouraged, appreciated and even expected, with scholars (among them Turkish ones as well) vying each other for positions within such associations for clout and prestige. It is telling that Keskin, the philosophy scholar who, as mentioned above, was the chief organizer of the Crossroads conference in 2006 in Istanbul and who went on to become the chairman of ASC, is not a member of KAD.

28 The scholars in the Turkish-medium universities, however knowledgeable in their own areas of specialization they may be, tend at times to be innocent of Western theories. They also tend to produce work that is descriptive rather than analytical or critical; academic selection pushes the bright minds into the more prestigious English-medium universities.

29 The issue of foreign scholars residing in the country and writing on Turks or Turkey although possessing only a superficial knowledge about them, yet vilifying them with great abandon and pleasure, has been discussed in the 2004 Pultar and Kırtunç essay, so I do not go into that subject here.

30 I would hope of course that due to the very nature of cultural studies, the members of the faculty of the cultural studies departments/programs in the universities mentioned above do not only refuse to take such a position, but are also vehemently and publicly critical of it.

31 A burial mound (kurgan) dating from the fourth century BC, discovered in the late 1960s near the town of Esik (Issyk) in Kazakhstan, contained the skeleton of a young man, probably a prince, clothed in a suit of gold, known since as the "Golden Man." Among the artifacts found interred with him was a vessel which contained writing that connects him, scholars believe, to the Saka Turks, known as Scythians ("Issyk Kurgan"). This is much earlier than the seventh and eighth centuries AD Orkhon (Orhon) Inscriptions (discovered in what is 
today Mongolia and deciphered at the end of the nineteenth century), containing the runictype writing which had been thought to be the earliest examples of writing by the Turks ( " Orhon Inscriptions” ). Of course, Western and Western-educated scholars find this approach problematic as for many of them Scythians are not Turks.

32 For example, a theory, espoused by Adile Ayda (1912-1992), Kazım Mirşan and Haluk Tarcan and their followers, advances that the Etruscans, who had a distinct culture already in 1100 BC, were Proto-Turks (for Etruscans as Proto-Turks, see e.g. Ayda 1985).

33 The turning point was the year 1999 when the $700^{\text {th }}$ anniversary of the founding of the Ottoman Empire was observed in the country with various celebrations and conferences. A year earlier, the country had celebrated the $75^{\text {th }}$ anniversary of the founding of the republic in great pomp; so perhaps it was felt the republic was sufficiently secure to confront old demons. Since then, the "bashing" of the Ottoman Empire has given way to ever-extending studies. This shift has created its own cast of characters: Halil İnalc1k, who had been living quietly in the USA as a retired professor of history (emeritus, Chicago University), was launched into a new career upon being invited to teach at Bilkent University. İnalcık is now known as having introduced a dimension of economics to Ottoman history; he also insists Ottoman history is very much part of European history and should be studied thus. Although he still teaches in the mornings, the 1916-born widower İnalckk leads a secluded life; the real star is the much younger İlber Ortayll, who is not only a prolific author but also a tv personality, appearing on various programs, never tiring of recounting various facets of Ottoman history. For their part in sustaining Ottoman studies in the United States, historians Cemal Kafadar (Harvard University) and Şükrü Hanioğlu (Princeton University) have been conferred the Presidential Grand Award for Culture and Art in 2010 and 2012 respectively. It eventually did introduce English partially as a working language, as foreign scholars working on Turkish subjects who were not in full command of Turkish yet wished to attend the conferences it organized started sending abstracts. Young Turks of Germany who were born in Germany and did not know academic Turkish were also allowed to present their papers in English. In 2005 (at the "Identity and Culture conference), the plenary lectures given by Jacob Landau and Geoffrey Lewis (on pan-Turkism and the Turkish language reform respectively) were translated simultaneously for the participants. In 2011 (at the "Space and Culture" conference), when Edward Soja and Setha Low spoke in English, the funds allocated by TÜBİTAK did not cover (the high-priced) simultaneous translation, but no one in the audience objected.

35 Schneider (Sabanc1 University) is the only one so far who has become a KAD member.

36 The extreme in this conduct is that of Bilkent University in Ankara which does not deem publications in Turkish by its faculty worthy of consideration, and so does not list them on its website.

37 The worldwide pressure to publish cultural studies work in English has been discussed in many Crossroads conferences, among them the 2006 Istanbul one, already alluded to above, so I do not touch upon that subject here.

38 And, naturally, it is only those scholars based in the West who possess legitimacy, and are considered as worth listening to. It is telling that at the 2006 Crossroads conference, Bilgi University chose as Turkish respondent to the keynote speaker an academic living and teaching in Paris, and not one of the many just as eminent Turkish scholars from Turkey itself.

39 Some observers see a massive activity lately of translation into Turkish of the theoretical work used in cultural studies as well as in social sciences in general, and find that the translated texts are being used by a considerable number of authors working in different fields, and thus believe that ignorance of the English language need no longer be an impediment.

40 There are of course exceptions, such as Abdülhamit Kırmızı (who holds a Ph.D. in Ottoman History) at the Istanbul Şehir University cultural studies program, to give just one example; 
but the prototype is Murat Belge, a Ph.D. in English Literature become a professor of comparative literature, now one of the prominent members of the Bilgi University faculty and of its graduate cultural studies program.

41 Some of the faculty in the cultural studies programs believe that the dissertations coming out of their programs have already started bridging this gap, with their students utilizing Western theoreticians' ideas in a way that is relevant to the Turkish situation; if true, one can only rejoice at it and patiently wait for the publication of these texts.

42 Although ideally speaking, the situation should or could have led to a crossfertilization.

\section{References}

ADM 5117 Issues in Turkish Cultural History: Popular Culture, Power, and Subalternity: http://mcs.metu.edu.tr/en/adm-5117-turkish-cultural-history, (accessed 1 April 2013).

Ayda, Adile (1985): Les Étrusques étaient des Turcs. Preuves, Ankara: Ayyıldız Matbaası.

Boğaziçi University Graduate Program in Critical and Cultural Studies: http://www.boun.edu.tr/Default.aspx?SectionID=652, (accessed 26 September 2011).

Bozdoğan, Sibel and Reşat Kasaba (eds) (1997): Rethinking Modernity and National Identity in Turkey, Seattle: University of Washington Press.

Büken, Gülriz, Laurence Raw \& Günseli Sönmez İşçi (eds) (1999): Popular Culture(s), Ankara: The British Council.

Courses - M.S. Program in Media and Cultural Studies [thesis and non-thesis], Middle East Technical University Gradutae School of Social Sciences: http://mcs.metu.edu.tr/en/courses, (accessed 1 April 2013).

CSSG Cultural Studies Study Group: http://warlight.tripod.com/, (accessed 26 September 2011).

Cultural Studies Course Descriptions, Istanbul Şehir University: http://www.sehir.edu.tr/en/Pages/Academic/Graduate/GraduateSchoolofSocialSciences/Culturel Studies/CourseDescriptions.aspx?PageID=42\&MenuID=1875, (accessed 1 April 2013).

Cultural Studies: What does it Study and How?, Istanbul Şehir University: http://www.sehir.edu.tr/en/Pages/Academic/Graduate/GraduateSchoolofSocialSciences/Culturel Studies/Home0709-7894.aspx?PageID=42\&MenuID=1873, (accessed 1 April 2013).

"Derviş Zaim”, Wikipedia, the Free Encyclopedia: http://en.wikipedia.org/wiki/Dervi\%C5\%9F_Zaim, (accessed 26/9/2011).

Erdem, Murat, Lois R. Helmbold \& Atilla Silkü (eds) (2012): Proceedings of [the ]Thirteenth International Cultural Studies Symposium “Change and Challenge”, İzmir: Ege University Press.

Erol, Nuran (2000): "Arabesque Culture as a Metaphor of the World in Turkish Society", Laurence Raw \& Ayşe Lahur Kırtunç (eds): Dialogue and Difference, Ankara: The British Council, 93-109.

Filler ve Çimen (Elephants and Grass) (2000): Dir. Derviş Zaim. Perf. Ezel Akay, Haluk Bilginer, Sanem Çelik, Bülent Kayabaş. Prod. Ali Akdeniz et al.

Graduate Courses - Sabanc1 University Faculty of Arts and Social Sciences Cultural Studies: http://cult.sabanciuniv.edu/en/courses/graduate, (accessed 1 April 2013).

Gölgeler ve Suretler (Shadows and Faces) (2010): Dir. Derviş Zaim. Perf. Settar Tanrı̈ğen, Buğra Gülsoy. Prod. Derviş Zaim.

"Issyk Kurgan", Wikipedia, the Free Encyclopedia:http://en.wikipedia.org/wiki/Issyk_kurgan, (accessed 28/10/2012).

Istanbul Bilgi University MA in Cultural Studies: http://pages.bilgi.edu.tr/graduates/ma-incultural-studies/default_eng.htm, (accessed 26 September 2011). 
Irzık, Sibel and Güven Güzeldere (eds) (2003): Relocating the Faultlines: Turkey Beyond the EastWest Divide, guest-edited special double issue of South Atlantic Quarterly, 102: 2-3.

İncirlioğlu, Emine Onaran \& Barış Kılıçbay (eds) (2011): Mekân ve Kültür, Istanbul: Tetragon.

İşçi, Günseli Sönmez, Dilek Direnç \& Züleyha Çetiner Öktem (eds) (2005): Inside Outside In: Emotions, Body and Society, İzmir: Ege University Press.

İşçi, Günseli Sönmez, Dilek Direnç \& Gülden Hatiboğlu (eds) (2007): When Away Becomes Home: Cultural Consequences of Migration, İzmir: Ege University Press.

Kandiyoti, Deniz and Ayşe Saktanber (eds) (2001): Fragments of Culture: the Everyday of Modern Turkey, London: Tauris.

Kırtunç, Ayşe Lahur, Gülriz Büken, Laurence Raw \& Rezzan Silkü (eds) (2001): New Cultural Perspectives in the New Millennium, İzmir: American Studies Association of Turkey, and the departments of American Culture and Literature and English Language and Literature of Ege University.

Kırtunç, Ayşe Lahur, Atilla Silkü, Kenneth W. Rose \& Murat Erdem (eds) (2003): Selves at Home, Selves in Exile: Stories of Emplacement and Displacement, İzmir: Ege University Press.

Kırtunç, Ayşe Lahur, Eleftheria Arapoglou \& Murat Erdem (eds) (2005): [City in (Culture] in City), İzmir: Ege University Press.

KÜLT Kültürel İncelemeler Dergisi: http://kultdergisi.com/kult-hakkinda/, (accessed 28 October2012).

Kültür Araştırmaları Derneği: www.kulturad.org, (accessed 26/9/2011).

Lewis, Geoffrey (2009): "Dil Reformu Toplumu Nasıl Böldü" [How Language Reform Divided Society], trans. Nazan Haydari-Pakkan and Gönül Pultar, Gönül Pultar (ed.): Kimlikler Lütfen: Türkiye Cumhuriyeti'nde Kültürel Kimlik Arayışı ve Temsili, Ankara: ODTÜ Yayınları.

Middle East Technical University Media and Cultural Studies Program: http://www.mcs.metu.edu.tr, (accessed 6 November 2012).

"Orhon Inscriptions", Encyclopedia Britannica: http://www.britannica.com/EBchecked/topic/432269/Orhon-inscriptions, (accessed 28 October 2012).

Parallel Trips (2004): Documentary film. Dir. Derviş Zaim and Panicos Chrysantou. Prod. Derviş Zaim and Panicos Chrysantou.

Pultar, Gönül (2005): "Küreselleşme Çağında Ezberler Bozulurken: Türk(iye) Kültürleri ve Kuramsal Çerçeve Arayışları" [As Received Wisdom is Being Shattered During the Age of Globalization: Cultures of Turks / Cultures of Turkey and the Search for a Theoretical Framework], Gönül Pultar \& Tahire Erman (eds): Türk(iye) Kültürleri, Istanbul: Tetragon, 19-37.

(ed.) (2009): Kimlikler Lütfen: Türkiye Cumhuriyeti'nde Kültürel Kimlik Arayışı ve Temsili, Ankara: ODTÜ Yayınları.

------ (ed.) (2012): Ă̆ır Gökyüzünde Kanat Çırpmak: Sovyet-sonrası Türk Cumhuriyetlerinde Kültürel Kimlik Araylşı ve Müzakeresi, Istanbul: Tetragon.

------ (ed.) (forthcoming): Imagined Identities: Identity Formation in the Age of Globalization. Syracuse, NY: Syracuse University Press.

Pultar, Gönül \& Ayşe Lahur Kırtunç (2004): "Cultural Studies in Turkey: Education and Practice", Review of Education, Pedagogy, and Cultural Studies, 26:2-3, 129-153. Also at www.kulturad.org/images/practise2.pdf (accessed 18 April 2013).

Pultar, Gönül, Emine O. İncirlioğlu \& Bahattin Akşit (eds) (2003): Kültür ve Modernite, Istanbul: Türkiye Kültür Araştırmaları Grubu and Tetragon.

Pultar, Gönül \& Tahire Erman (eds) (2005): Türk(iye) Kültürleri, Istanbul: Tetragon.

Raw, Laurence (2004): "The Practice of Cultural Studies in the Turkish Republic", Review of Education, Pedagogy and Cultural Studies, 26:2-3, 111-127.

------ E-mail message to the author on 26 August 2011.

(2011): Exploring Turkish Cultures, Newcastle upon Tyne: Cambridge Scholars Publishing.

Raw, Laurence \& Cem Taylan (1993/1994): "Teaching British Cultural Studies in Turkey", academia.edu: 
http://baskent.academia.edu/LaurenceRaw/Papers/392534/Teaching_Cultural_Studies_in_Turk ey_1994_with_Cem_Taylan_, (accessed 26 September 2011).

Raw, Laurence, Gülriz Büken \& Günseli Sönmez İşçi (eds) (1997): Crossing the Boundaries: Cultural Studies in the UK and US, Ankara: The British Council.

----- (eds) (1998): The History of Culture: The Culture of History, Ankara: The British Council.

Raw, Laurence \& Ayşe Lahur Kırtunç (eds) (2000): Dialogue and Difference, Ankara: The British Council.

Remington, Pete (ed.) (2001): Globalization and Transcultural Issues in the New World Order, advisory eds. Günseli Sönmez İşçi \& Gülriz Büken, İzmir: Ege University Press.

Sabancı University Faculty of Arts and Social Sciences Cultural Studies: http://cult.sabanciuniv.edu/en, (accessed 1 April 2013).

Schneider, Annedith (2002): "The Institutional Revolutionary Major? Questions and Contradictions on the Way to Designing a Cultural Studies Program in a New Turkish University", International Journal of Cultural Studies, 5:4, 393-404.

Silkü, Atilla, Murat Erdem \& Patrick Folk (eds) (2009): Memory and Nostalgia, İzmir: Ege University Press.

Tabutta Rövaşata (Somersault in a Coffin) (1996): Dir. Derviş Zaim. Perf. Tuncel Kurtiz, Ahmet Uğurlu. Prod. Istisnai Filmler ve Reklamlar (IFR).

Theses - Sabancı University Faculty of Arts and Social Sciences Cultural Studies, Sabancl University, http://cult.sabanciuniv.edu/en/research/ma-thesis, (accessed 1 April 2013).

“Türkiye'de Dernek Sayısı 85 bin'i Buldu”, Türkiye Cumhuriyeti İ̧işleri Bakanlı̆ğ Dernekler Dairesi Başkanlığı:


12\&lang=tr, (accessed 3 October 2012).

Türkoğlu, Nurçay \& Sevilen Toprak Alayoğlu (eds) (2009): Karaelmas 2009: Medya ve Kültür, Istanbul: Urban.

Welcome to FASS [About Our Vision], Faculty of Arts and Sciences Sabancl University: http://fass.sabanciuniv.edu/about/our-vision, (accessed 6 November 2012). 



\title{
Portuguese Cultural Studies/ Cultural Studies in Portugal: Some Thoughts on the Making and Remaking of a Field
}

\author{
By Sofia Sampaio
}

\begin{abstract}
This article discusses the overall situation of cultural studies in Portugal. It starts by analysing some of the courses and graduate programmes currently on offer. The results suggest that cultural studies is experiencing a fast academic expansion. While this seems to be entangled with top-down institutional changes, in the wake of the Bologna process and the turn to the cultural/ creative industries and as part of a more general shift to the 'new economy', there are reasons to believe that alternative understandings of cultural studies have not died out. The name 'cultural studies' continues to cause unease in some academic quarters (namely, in literary studies) and there is ambiguity regarding what is meant by it. Cautioning against the tendency to reduce Portuguese cultural studies to a straightforward import from the Anglophone world, I argue for the need to conduct historically informed research on local strands and traditions of cultural theory and critique. I conclude that only a combined synchronic and diachronic approach - one that is sensitive to national and transnational contexts and intersections - will allow us to gain a better understanding of the deep-running contradictions that characterise the field, helping us to clarify the stakes and reconnect to a socially relevant and critique-orientated intellectual project.
\end{abstract}

Keywords: Cultural studies, Portugal, Bologna, 'new economy’, cultural critique. 


\section{Introduction}

The story of the emergence, ascent and institutionalisation of cultural studies has been told several times in the English-speaking world, where cultural studies originally appeared (first around the figures of Richard Hoggart, E.P. Thompson and Raymond Williams and then under the formative influence of Stuart Hall and the Birmingham school) and where it has flourished over the past three decades. In Portugal, however, this story remains to be told. This applies whether we take Portuguese cultural studies to be largely derivative of an international, and hegemonic, Anglo-American cultural studies strand (which the direct translation into 'estudos culturais', no doubt, suggests) or understand it in a more nuanced way, as a specific approach to culture and its study that must be connected to earlier intellectual practices, forged locally, within and in relation to certain national institutions, notwithstanding their links with other international formations.

The article is divided into two: in the first section I report on the current state of cultural studies in Portuguese universities and research centres, especially by looking at the presence of cultural studies in university courses and graduate programmes. My findings confirm the general idea that cultural studies - or something that goes by that name - is experiencing a fast academic expansion. Many researchers can now relate to cultural studies ideas or practices, even if loosely, and some use it to describe their research interests. However, this expansion seems to be - perhaps atypically - more entangled with internal, top-down institutional changes (triggered or facilitated by the Bologna process, on the one hand, and a growing interest in the cultural industries, on the other) than with overtlywaged cultural, political and academic wars. Tensions do exist - the naming of 'cultural studies' continues to raise discomfort in some academic quarters (namely, in English and American studies) - but they appear to have been sidestepped by institutional reforms, which perhaps explains why cultural studies is having a relatively quiet success story within certain academic quarters, while remaining not quite accepted, in others.

In the second section, I problematise these findings, stressing the need to complement this analysis with an account of other, more localised, intellectual strands that have also flowed into the cultural studies project. Further research is needed to trace these hidden lineages and genealogies and unravel the ties between local and national projects and agendas, on the one hand, and international and transnational projects, on the other - in the guise of the 'radically contextualist work' that Lawrence Grossberg has identified cultural studies with (Grossberg 2010). The full grasp of the field's current tensions and contradictions, as well as the future of socially relevant and critique-orientated approaches to culture, rest upon such research. ${ }^{1}$ 


\section{The Institutional View}

Cultural studies is on the rise in the Portuguese academia. 2010 saw the launching of two doctoral programmes in this area: the programme jointly run by the Universities of Aveiro and Minho (two younger state universities located in the north), announced on the official web site as the 'first doctoral programme in cultural studies in Portugal'; and the programme offered by a private college, the Faculty of Human Sciences of the Portuguese Catholic University, based in Lisbon, in close association with the Centre for the Study of Culture and Communication (CECC), ${ }^{2}$ and as part of a vaster inter-institutional programme called 'the Lisbon Consortium'.

Both programmes fall in line with dominant international trends in cultural studies, bringing together research interests that are common to the humanities and the social sciences, especially around the topic of communication. This is especially clear in the first case, which combines a strong humanities component (ensured by the Department of Languages and Cultures of the University of Aveiro) with communication studies (ensured by the Communication and Society Research Centre, or CECS, of the University of Minho). Sociology, geography, history, philosophy, anthropology, psychology and heritage ('património') provide other interdisciplinary links. The programme presents itself as a response to the growing importance of culture in the job market - the cultural industries are mentioned - and promises to 'produce' professionals in the areas of: 'cultural creation, cultural promotion, cultural animation, cultural mediation and cultural dissemination'. The objective is to turn out professionals who are qualified to work in public libraries, book publishing, the production of information and cultural events, cultural associations, embassies, institutes, foundations, cultural centres, and the like. The programme also promises to equip students with the skills to work in multidisciplinary teams as problem-solvers in the areas of sustainable development; intercultural communication; business ethics; film and genre studies; media studies; internet studies; post-colonial studies; conservation, management and promotion of material and immaterial heritage; audience creation; cultural tourism; cultural marketing; cultural policies; biopower; biopolitics; human genomics; the 'anthropotechnological' imaginary, etc. Its problem-solving orientation is clearly stated: the future degree-holders are expected to be able to deal with problems concerning the populations and public powers (such as social discrimination; xenophobia; nationalisms; social tensions and low civic participation); the economic powers (for instance, through the creation of museums, festivals, events, tourist guide material and culture industries in general); and the various social groups who struggle for the recognition of alternative representations of themselves and the world or who demand that new socio-cultural practices be legitimated. One last objective is to encourage research on and critical engagement with these topics. Students have to take three obligatory courses - cultural studies 
theories and methodologies; intercultural communication; and sociology of culture - plus an optional course. ${ }^{3}$

Interdisciplinarity and cultural policy are also central to the idea of cultural studies endorsed by the CECC, at the Faculty of the Human Sciences of the Portuguese Catholic University. The main objective of this programme, as stated in the English brochure of the Lisbon Consortium, is 'to bring about the professional integration of students through advanced training in the multidisciplinary field of Cultural Studies based upon cooperation in academic reflection, scientific research, programming and cultural management'. ${ }^{4}$ Interdisciplinary 'interaction' across the fields of 'cultural studies, literary and artistic studies, performance studies, translation and media studies, cinema and history' is stressed. The master's programme offers the following courses: 'Culture, Art and Power'; 'Cognition and Creativity'; 'Performance Theory'; 'Cultural Entrepreneurship'; 'Visual Culture'; 'Culture and the Environment'; 'Globalization and Modern Culture'; and 'Writing Europe'. The doctoral programme shares two of these core courses (namely: 'Culture, Art and Power', and 'Performance Theory'), to which have been added five more: 'Cyberculture'; 'Visual Arts and Performance'; 'Literature and Modernity'; 'Issues in Cultural Studies and Film Studies'. ${ }^{5}$ In Portuguese, the names of these courses are slightly different, betraying greater proximity to literature and the 'study of culture'. ${ }^{6}$ The programme's relationship with cultural studies is rather ambiguous. Although the English brochure of the Lisbon Consortium uses the term 'cultural studies', the Portuguese brochure refers throughout to 'estudos de cultura' (rather than 'estudos culturais'). More importantly, the syllabi of most of the core courses make few references to the canonical works of cultural studies - this is particularly evident in 'Issues in Cultural Studies' ('Questões de Estudos de Cultura'), the key theoretical course, taught by a German lecturer and drawing essentially on German authors, which points to an understanding of culture that is more in line with the Kulturkritik tradition, in Francis Mulhern's terminology (2000). ${ }^{7}$

Like the University of Aveiro and the University of Minho (but from what seems to be a more status quo position), the Catholic University and the Lisbon Consortium are clear about their commitment to interact with the 'cultural economy', described, in their brochure, as a growing economic sector, responsible for 2.5\% of employment in Portugal. But if Aveiro and Minho adopt a more critical line of cultural studies - being closer to the four pillars proposed by Johan Fornäs, namely: culture, communication, contextualization and critique (Fornäs 1999: $132)^{8}$ - the programme of the Catholic University is weaker on either contextualization and critique, assuming more clearly an entrepreneurial job-orientated agenda. One of its major objectives is the 'professional integration of students', namely in cultural programming and management. Its incorporation in the Lisbon Consortium, alongside key elite institutions like the National Theatre Museum, the Portuguese Film Institute ('Cinemateca Portuguesa - Museu do Cinema'), the 
National Cultural Centre, the Calouste Gulbenkian Foundation, the Culturgest and the Lisbon Municipal Council, places it in a strong position to achieve this goal. ${ }^{9}$

Given the historical links of cultural studies to literature, one would expect to find a vibrant cultural studies scene in the humanities - especially in the context of English and American Studies. However, this is hardly the case - at least on an institutional level. The Faculties of Letters of the University of Porto and of the University of Lisbon offer very few graduate programmes in cultural studies, and these are to be found outside of their English departments. In the case of the former, the only post-graduate programme that could be linked to cultural studies is based in the Department of Portuguese and Romance Studies. Running since 2007, this is an M.A. in Literary and Cultural Studies and Inter-arts ('Mestrado em Estudos Literários e Culturais e Interartes'), a merging of previously separate M.A. programmes in literature. ${ }^{10}$ Its focus is still on literature, but it now offers the students a more flexible syllabus, in keeping with the Bologna convention that it professes to follow. The course is divided into two branches: 'Romance and Classical studies' ('Estudos Românicos e Clássicos'), with six variants ('Iberian cultures'; 'literary aesthetic'; 'French and Francophone studies'; 'Portuguese literature and literatures in Portuguese'; 'Classical literatures' and 'theory of literature'); and 'Comparative Studies and Intercultural Relations' ('Estudos Comparatistas e Relações Interculturais’), also with a focus on literature (namely, travelogues) and translation. The student will have a degree in one of the following scientific areas: literary criticism; cultural studies; cultural studies - classics; literature and comparative literature. ${ }^{11}$ Students can also proceed to the doctoral programme (in 'Romance Literatures and Cultures'), and they will specialise either in Romance literature or in cultural studies (i.e. 'estudos culturais'). As for the Department of Anglo-American Studies, its well-established M.A. programme in Anglo-American Studies has increased its range of optional courses, among which we can now find 'Cultural Studies' and 'Inter-art Studies and the Representation of Woman' (English in original). ${ }^{12}$ Its three areas of specialisation are: literature, culture and translation.

Similarly, the Department of English Studies of the Faculty of Letters of the University of Lisbon offers no specific programme in cultural studies. This absence appears the more striking if we consider that this was where recently-retired Professor Álvaro Pina, one of the greatest advocates of cultural studies in Portugal, used to work. ${ }^{13}$ Some of the courses currently included in the department's master's and doctoral programmes do draw on cultural studies theories and methodologies; however, the Centre for English Studies (CEAUL/ ULICES), the department's associated research centre, shows no clear commitment to pursuing systematic work in the field. This contrasts with the Centre for Comparative Studies (CEC), based in the same institution, where a strong interdisciplinary framework seems to have encouraged and facilitated the adoption of cultural studies approaches. This centre has three major research areas: (1) Intercultural Studies, 
dedicated to the study of travel literature, utopian texts, and translation; (2) 'Literary and Cultural European Studies', which pursues the study of Portuguese and Lusophone contexts vis-à-vis Europe; (3) 'Intersemiotic Studies', or 'Interart', concerned with the relations between literature, on one side, and film, theatre, painting, and architecture, on the other. ${ }^{14}$

Finally, the Faculty of Letters of the University of Coimbra - another bastion of classic humanities - evinces the same general trends. Following the recent Bologna-orientated reorganisation, in 2007, the new Department of Languages, Literatures and Cultures (which brings together people doing what used to be called 'Classical', 'Romance', 'Anglo-American' and 'Germanic' studies) offers, at an undergraduate level, a course called 'Introduction to Cultural Studies' ('Introdução aos Estudos Culturais') as an option for the different linguistic branches of the Modern Languages programme. ${ }^{15}$ It also offers an M.A. in Literary and Cultural Studies, which, despite the name, is closer to a comparative literature programme, being very much in line with the M.A. in English and American studies also run by this department. ${ }^{16}$

Generally speaking, all the master's and doctoral programmes offered by this Faculty seem to be centred on literature. Two recent developments, however, suggest that the situation may be changing: one is the M.A. and PhD in Feminist Studies - the only programme of the kind in Portugal, running since $2010 ;{ }^{17}$ the other is the doctoral programme, also launched in 2010, called 'Advanced Studies in the Materialities of Literature'. While both are still very much literatureorientated, the former is also described as 'interdepartmental', accepting students from all academic backgrounds, and the latter proposes to study literature vis-àvis the new technologies of communication and the other arts, stating as its ultimate goal to contribute to the 'renovation' of literary studies in Portugal in a manner that is 'already under way in the Anglo-American world and Northern Europe' and as part of 'the larger project of rethinking the Humanities in the era of new media'. Accordingly, the students are expected to develop, among other things, 'competences, skills, and research methods associated to the scientific domains of theory of literature, cultural studies, inter-art studies and other emerging fields' ${ }^{18}$

Outside of this account I have left the social sciences: history, sociology and anthropology, in particular, are having an active role in the current expansion of cultural studies (probably on a larger scale and with more far-reaching implications than the humanities). There is no doubt that many of the problems and themes that interest cultural studies cross over to these other disciplines and fields. Bibliographical references to cultural studies authors have become common in sociology and history (namely, in urban history and film history). For reasons that have been widely discussed, culture has been gaining ground, in the social sciences, as a research interest and many social sciences research centres now employ cultural studies researchers or work closely together with them. This is the case of the Centre for Social Studies (CES), chaired by sociologist Boaventura Sousa 
Santos, which has several projects in the area of cultural representation and maintains active collaborations with the Faculty of Letters of the University of Coimbra (the doctoral programme in Feminist Studies is one of them). This is also the case of the Centre for Research in Anthropology (CRIA), where I am based, which addresses culture as a subject and a problem in many of its projects, seminars and research lines, not least the one specifically dedicated to the study of cultural practices, politics and displays. ${ }^{19}$

\section{Underlying Problems and Tensions}

What seems to surface from the brief overview offered above - which is not and does not purport to be exhaustive - is that the on-going expansion of cultural studies in Portugal is greatly indebted to changes taking place at an institutional level. Two policy interventions have been of particular relevance: the implementation of the Bologna accords (which set in motion the so-called Bologna 'process') and the policies that have raised the economic profile of the cultural-turned-creative industries. The Bologna accords, signed in 1999, laid the foundations for the building of a common European Higher Education Area, encouraging interdisciplinary approaches and a more flexible curriculum. The document's aim - to allow students to customise their education and become more mobile within the European zone - has indirectly facilitated the engagement with cultural studies. Indeed, most of the new programmes discussed above acknowledge Bologna. ${ }^{20}$

The adoption of the creative industries policy model has likewise been responsible for this sudden institutional interest in cultural studies. This model, developed by Tony Blair's New Labour in the late 1990s to boost Britain's export trade, embodies the general shift to the 'new economy', which was largely dependent upon the expansion of the new information technologies (mostly software, computer games and electronic publishing) and the extraction of value from intellectual property rights (Miller \& Yúdice 2002; Garnham 2005; Ross 2009: 26). Incidentally, the model itself became one of Britain's most successful exports (Ross 2009: 20), officially arriving in Portugal during the 2005-2011 Socialist government led by José Sócrates. ${ }^{21}$ As a result, despite lack of empirical data (Miller 2004; Oakley 2004; Garnham 2005), the idea that culture holds the key to the country's economic problems enjoys now wide currency, even among cultural workers, who often turn to it in an attempt to defend the sector and secure their jobs. The much-trumpeted idea that there are great economic returns to be obtained from the cultural industries clearly informs (arguably, to a different extent) the doctoral programmes in cultural studies run by the Catholic University and by the Universities of Aveiro and Minho, making their engagement with more critical views less probable.

In this general favourable mood, it is hardly surprising to find that open academic confrontations over cultural studies have practically disappeared. An in- 
creasingly large number of students, lecturers and researchers are now claiming the label 'cultural studies' to describe their work and research interests. Work on or related to cultural studies is being carried out in different academic quarters from communication research centres (like the CECS, based in the University of Minho) to more classic literature centres (like the CEAUL/ ULICES and the CEC, based in the Faculty of Letters of the University of Lisbon, or the CETAPS, based in the Faculty of Letters of the University of Porto and the New Lisbon University). ${ }^{22}$ We can also expect to find cultural studies scholars (in a broader or narrower sense of the term) in more recently formed research centres with a deliberate focus on interdisciplinary work and the cultural/ creative industries (like the CECC, based in the Catholic University), or on the idea of 'inter-culture' (like the CEI, based in ISCAP, in Porto). ${ }^{23}$ The major research lines of all these centres overlap, differences being more of nuance and accent - to do with the centre's chief disciplinary affiliation, its institutional origins, contingent academic strategies, and the background and training of its main researchers - than with clearlystated theoretical or theory-driven projects. Further research would be needed to clarify each of these aspects.

Nevertheless, the label 'cultural studies' continues to be wrapped up in ambiguity, causing unease in certain quarters. As I have noted above, the brochure of the Lisbon Consortium adopts the term 'cultural studies' in its English version and 'estudos de cultura' (rather than 'estudos culturais') in its Portuguese version. Yet, in another English-speaking context - the 2011 meeting of the Portuguese Association for Anglo-American Studies (APEAA) - the option falls on 'studies of culture' ${ }^{24}$ These different wordings suggest the persistence of old tensions, which Álvaro Pina identified and wrote about in the late 1990s (incidentally, in response to a notice which appeared in an issue of the APEAA newsletter, disclaiming cultural studies). For Pina, cultural studies had to contend against 'the official knowledge in English and American studies' that, until April 1974, had been philologically-based - 'divorced from the present, blind to the quotidian and hostile to the contemporary' - and that, by the 1990s, was bound to a literary-studies paradigm, in which literature was first and foremost a 'field of distinction' (Pina 2000: 2 , 3). In such a context, 'cultural studies [was] not there, officially not, strategically not' (Pina 2000: 2), its only alternative being to exist as 'a place conquered in the space of the other' (Pina 2000: 4). Pina was then reflecting on the conditions of his own practice, as a teacher of English culture courses in a classic English department, but his words could, no doubt, find resonance in other cultural studies quarters.

The situation of cultural studies has, in the meantime, considerably changed. One of the effects of the market-turn in the academia has been the decline of the literary-studies paradigm - or, to put it more accurately, its redefinition to suit new market and governance aims. In many respects, and with no lack of irony, cultural studies has become something of a survival strategy to the humanities 
(and, to a lesser extent, the social sciences). The question, today, is not so much how to conquer 'a place in the space of the other' (as the 'other' now often bounces back to us in the guise of the self), but how to remain true to a cultural studies practice that is still interested in studying 'culture as such' (Pina 1999), in relation to its (and our) contexts, so as to tease out its precise meanings, usages and power alignments - in keeping with cultural studies' claims to a 'radical contextualization’ (Grossberg 2006: 7; Grossberg 2010: 30, 40).

One such context pertains to the national-international (or even transnational) articulations that underpin Portuguese cultural studies. For most of us, the notion that cultural studies arrived in Portugal in the 1990s, as part of a vaster international 'success story', begs little examination. This was when the ideas and theoretical frameworks that were shaping the debates on culture and power in the Anglo-American world were being made available (courtesy of so-called 'globalization') to Portuguese academics. As in other regions (namely, Scandinavia), cultural studies came in tow with the growing attention accorded to popular culture, youth culture and the media in the social sciences. Its presence was more controversial in the humanities, where cultural studies' trademark attack on the canon, together with its challenge of disciplinary boundaries, met with resistance, especially in more traditional quarters like literary studies (Sanches 1999; Silvestre 1999; Pina 2000). ${ }^{25}$

Indeed, the idea that 'estudos culturais' was an import from the Englishspeaking world dominates perceptions of the origins of cultural studies in Portugal. Although partly true - cultural studies is a 'travelling concept' (Bal 2000), owing its propagation to contact between academics and their work - this says little about the actual practices, meanings and conditions that have developed under its banner. As Pierre Bourdieu has pointed out, the transfer of ideas in an international context always entails a degree of 'structural disjuncture' (Bourdieu 1995/2000: 242), which is to say that there is always a gap between the projects (and terms) that are being compared. No new projects and terms develop in a vacuum, for their meanings can only be found in relation to existing 'local' projects and traditions, and their present forms and conditions. The point is not so much that the latter are 'home-grown', as opposed to 'imported' (even home-grown formations are influenced by external constellations), but that they are there, along with their own supporting and oppositional networks. These cannot be ignored or simply written off, lest we risk misrecognising the power relations and correlations that make up the field and misunderstand what is really going on, what is really at stake.

This, I believe, applies to Portuguese 'estudos culturais' - or cultural studies in Portugal - in which various national and transnational strands of cultural analysis and critique have converged. The kind of concerns associated with cultural studies had been troubling sectors of the Portuguese intelligentsia long before the 1990s. According to Álvaro Pina, '[c]ultural studies appeared on the Portuguese academ- 
ic scene in the first year after the April Revolution - from left Leavisite, Marxist and structuralist positions - as part of the struggle for an educated, participatory democracy' (Pina 1999: 2). The role that culture and cultural theory (or even 'metaculture') played in this struggle has been under-examined, but there is no doubt that they had a role to play, including outside the academia. The famous campaigns of civic and cultural action that the Movement of the Armed Forces (MFA) carried out between 1974 and 1975 testify to a deep political awareness of cultural issues (Almeida 2009), as do the numerous cultural groups and actions (spontaneous or politically-driven) that also appeared at the time and immediately afterwards. Further research on the theories and usages of culture is called for, namely to identify some of the 'intellectual spaces and practices of hope' (Pina 2003) that emerged at different historical moments (another example would be 'neo-realismo', which became influential in the 1940s - cf. Pina 2003).

In each of these moments the weight of national and transnational elements and its power implications are well worth looking into. As suggested above, apropos of the Lisbon Consortium brochures and the 2011 APEAA conference, the way the label 'cultural studies' is adopted or rejected according to different (national or international) contexts is an index of the different power strategies that cultural studies is capable of mobilising. On the one hand, there is symbolic capital to be gained from the international credentials of cultural studies, or even, in some quarters, from its reputation as an irreverent and marginal counter- or antidiscipline; on the other hand, these gains may come at the expense of a deeper and more direct involvement with local and national public debates. In the late 1990s, Álvaro Pina referred to the dilemma that a cultural studies scholar working in Portugal would often run into: to write a paper on a Portuguese topic and reduce one's chances of being accepted in an international cultural studies conference or to increase those chances by accommodating to a 'theme or a problematic which has become relevant in English-speaking countries' (Pina 2000). While this dilemma has become, to a certain extent, less acute - work on Portuguese cultural studies can now be presented and discussed on a rising number of national and international occasions and publications - the main problem remains, namely: how to produce work that is internationally relevant without failing our responsibilities as public intellectuals? In other words, how to combine our professional need to publish in English (which, among other things, requires that we fit in with an international/ Anglophone research agenda) and our desire to intervene as public intellectuals in the places where we live and work? Who should be our prime interlocutors? ${ }^{26}$

\section{By Way of Conclusion}

The present success story of cultural studies in Portugal has been largely built on an institutional level, being the result of top-bottom interventions more than overt 
intra-institutional conflicts. The shift to the 'new economy', which elevates culture to a key economic activity, has proved particularly efficacious in shaping a cultural studies agenda in Portugal. The cultural-turned-creative industries, we are told, are going to regenerate our cities, stimulate our production, increase the GDP, invert the balance of trade (increasing the exports through a shift from products to services), reverse the current budget deficit and so on and so forth. Last but not least, all of this is going to save the (somewhat resentful) humanities. In a context of high academic instability, where job scarcity and precariousness reign supreme, one cannot overestimate the pressures being currently put on academics and researchers to become increasingly more 'productive', seriously damaging their chances to commit to a more encompassing, truly interdisciplinary and socially-grounded intellectual project.

And yet such commitment is needed. Faced with an acute economic crisis and a programme of extensive public cuts (in line with the recent IMF-EU-ECB intervention), Portugal is now experiencing a moment of fast change and great intellectual confusion. More critical thinking is required, not less. Given its proven abilities to establish meaningful connections between apparently disconnected things, cultural studies is particularly well-placed to help us to make sense of the new culture-power alignments that are currently taking shape, of the present 'conjuncture' (Grossberg 2010), if we prefer, of which cultural studies is necessarily a part. And there is no shortage of research topics, concerning, for instance: (1) the new orthodoxies formed around the 'cultural industries' and the 'new economy' which, as a rule, exclude inquiries into the quality of work life in the creative industries (Ross 2009: 27), where precarious employment and deep income disparities are rampant (Miller \& Yúdice 2002); (2) the relationship between national and transnational cultural studies projects (or even between cultural studies and other intellectual movements); (3) the apparent conversion, in some academic quarters, of cultural studies into 'intercultural studies'. There is much to commend cultural studies for: ranging from its proven ability to mobilise literary critical analysis and reading skills (not only for meaning, but also for significance Grossberg 2010: 194) to its uncompromising commitment to complexity (Grossberg 2010: 16-17) and context. ${ }^{27}$ Having said that, there are also doubts concerning its 'transformative' politics, which (as everything else in this intellectual practice) cannot be taken for granted. What form will this transformative impetus take, considering the present moment of forced national 're-invention', in which much that has been thought 'solid' is rapidly 'melting into air'? How will these politics affect and be affected by other competing intellectual and political formations? Whether a cultural studies formation will prove useful in the current context or give way to other, more socially relevant, intellectual projects (possibly developing outside the academia) remains to be seen. In any event, the principled study of the relations between culture and power in Portugal, whatever the name it choses to adopt, will certainly depend on our ability - as academics, public intellectuals, 
activists or cultural studies practitioners - to understand the national, local and institutional conditions of our own practice.

\section{Acknowledgements}

This paper is an expanded version of a text presented at the Spotlight session 4 'South European Cultural Studies: The Mediterranean', as part of the Current Issues in European Cultural Studies Conference. I would like to thank Chantal Cornut-Gentille d'Arcy for her kind invitation to participate in this panel. I would also like to thank Maria João Ramos Silva for commenting on an earlier draft. The research presented here benefited from funding from the Portuguese Foundation for Science and Technology (FCT).

Sofia Sampaio is a Research Fellow at the Centre for Research in Anthropology (CRIA), in the Instituto Universitário de Lisboa (ISCTE-IUL), in Lisbon, Portugal. As part of her postdoctoral project, she is currently looking into the relationship between cinema and tourism. Her research combines methods and insights from film studies, history (including archival work) and anthropology. She is also interested in the geneology of intellectual movements and formations and their relation to national and transnational contexts. E-mail: psrss@iscte.pt

\section{Notes}

1 My assessment of the present situation of cultural studies in Portugal is far from comprehensive and acknowledges the need for further research. This would include, for instance, a systematic analysis of cultural studies publications (original and in translation), as well as interviews to some of its chief protagonists. I hope this paper may stimulate other reflexive engagements with past and present developments in the field.

2 The CECC ('Centro de Estudos de Comunicação e Cultura') is a research centre dedicated to the promotion and development, from a multidisciplinary perspective, of the study of culture, literature, translation, language and communication. Its key research interests are: the study of cultural creation in modernity, the inter-semiotic study of mediation (Luhmann, Kittler), the intercultural dialogue/conflict, and the study of translation, both as an inter-linguistic phenomenon and a process of cultural mediation and self-representation. It has three main research lines: 'Culture and Conflict'; 'Translating Europe across the Ages'; and 'Media, Technology, Contexts’. See

http://www.fch.lisboa.ucp.pt/site/custom/template/ucptpl_fac.asp?SSPAGEID=934\&lang=1 \&artigo=4479\&artigoID=4479 (accessed 19 May 2011).

3 For information on this programme, see: http://www.comunicacao.uminho.pt/ensino/content.asp?startAt=2\&categoryID=759\&newsID $=2034$ (accessed 14 May 2011). All translations from the Portuguese, unless otherwise stated, are my own.

4 See p. 4 of the Lisbon Consortium brochure: 
http://www.fch.lisboa.ucp.pt/resources/Documentos/brochuras_cursos/FCH_Consortium_bro chura_FEV11.pdf (accessed 18 May 2011)

5 Lisbon Consortium Brochure, p. 4, at: http://www.fch.lisboa.ucp.pt/resources/Documentos/brochuras_cursos/FCH_Consortium_bro chura_FEV11.pdf (accessed 18 May 2011)

$6 \quad$ In Portuguese, 'Globalization and Modern Culture’ becomes ‘Tradução e Globalização’ (i.e. 'translation and globalization'), whereas 'Issues in Cultural Studies’ is rendered as ‘Questões de Estudos de Cultura'. See:

http://www.fch.lisboa.ucp.pt/site/custom/template/ucptpl_fac.asp?SSPAGEID=924\&lang=1 \&artigo=4497\&artigoID=4498 (accessed 18 May 2011). For the syllabus and reading lists see also:

http://www.fch.lisboa.ucp.pt/site/custom/template/ucptpl_fac.asp?SSPAGEID=926\&lang=1 \&artigo=4566\&artigoID=4567 (accessed 18 May 2011).

7 For the syllabus of this course, see: http://www.fch.lisboa.ucp.pt/resources/Documentos/programas_doutoramentos/DEC_Questo esEstudosCultura.pdf (accessed 23/05/2011). References to cultural studies works do appear in the syllabi of one of the core courses ('Cultura, Arte e Poder') and in some of the optional courses (such as 'Television Studies' and 'Creative Industries: Theory and Practice’).

8 This is clear in Maria Manuel Baptista’s text on cultural studies (Baptista 2009). The author is the director of the Aveiro and Minho doctoral programme.

9 The National Cultural Centre is a cultural society founded in 1945; the Calouste Gulbenkian Foundation is the longest-running private Foundation in Portugal (it is also one of the most active, especially in the arts). Finally, the Culturgest is the cultural branch of Portugal's major bank - still state-owned at the time of writing, but probably not for long.

10 Namely, 'Mestrados em Literatura e Cultura Comparadas, Literatura Portuguesa Moderna e Contemporânea e Teoria da Literatura / Cursos Integrados de Estudos Pós-Graduados em Culturas Ibéricas e em Literaturas Românicas'. See this Faculty’s report on the Bologna process, or 'Relatório da concretização do processo de Bolonha, anos lectivos de 2006/2007 e 2007/2008', Faculdade de Letras da Universidade do Porto, p. 12, at: http://sigarra.up.pt/flup/web_gessi_docs.download_file?p_name=F12785065/Relatorio_Bolo nha_FLUP20092.pdf (accessed 13 May 2011).

11 For more information, see: http://sigarra.up.pt/flup/cursos_geral.FormView?P_CUR_SIGLA=MELCI (accessed 13 May 2011).

12 See http://sigarra.up.pt/flup/noticias_geral.ver_noticia?P_NR=2822 (accessed 14 May 2011). I could not access the syllabi of these courses.

13 Álvaro Pina and the group of graduate students that met under the Culture and Society graduate programme were active in the foundation of the Iberian Association of Cultural Studies (IBACS), which formally took place in 2001, at the University of Alcalá de Henares. Between 2002 and 2005, the group was also involved in the organisation of the three editions of the Language, Communication and Culture international conferences, as well as the 9th International Culture and Power Conference, one of the largest cultural studies conferences ever organised in Portugal, which was hosted by the Faculty of Letters of the University of Lisbon, in November 2003. This conference had four international keynote speakers - Chantal Cornut-Gentille d'Arcy (University of Zaragoza), Handel K. Wright (University of British Columbia), Mica Nava (University of East London), and Lawrence Grossberg (University of North Carolina at Chapel Hill) - and circa 130 papers. For further information, including announcements and the programme, see: http://mundiconvenius.pt/2003/cultural/ (accessed 19/05/2011). The Portuguese participation in the IBACS is, to my knowledge, currently very low. On the failure of the 'Iberian project', see Cornut-Gentille D’Arcy (2009). 

In reflection about cultural studies in France, Anne Chalard-Fillaudeau has also acknow edged the impact of Bologna in the field (2009: 834; 847). For a more critical take on this issue, linking Bologna to the educational needs of global capitalism, see Allaine Cerwonka's discussion of cultural studies in the former state socialist countries of Central and Eastern Europe and the former Soviet Union (2009: 727-729).

21 In Portugal, the two landmark policy-driven documents on the creative industries are The Economy of Culture in Europe, a study prepared by the KEA for the European Commission (2006), as part of the Lisbon 2000 agenda, and the report on the 'cultural and creative sector', prepared by Augusto Mateus \& Associados (2010) for the then Minister of Culture, Gabriela Canavilhas (cf. Silva 2012: 61-63).

22 CETAPS is the acronym for Centre for English, Translation and Anglo-Portuguese Studies.

23 The Centre for Intercultural Studies (CEI) is based in the Institute of Accounting and Administration of Porto (ISCAP), a public institution that is part of the Polytechnic Institute of Porto. For the kind of work it promotes, see the programme of the II International Conference on Intercultural Studies (ISCAP, 25 - 27 May 2011), at:

http://www.iscap.ipp.pt/ cei/II_Congresso.html (accessed 17 May 2011). The conference was strong in papers on intercultural representation (especially in literature and cinema). It also included panels in comparative law across cultures, intercultural communication, translation studies, cultural tourism, travelogues and gender studies. The large paper turnout suggests that these topics are extremely popular at present.

24 'Studies of culture' (English in original), defined in the call for papers as a 'general area', was the name of the panel organised by the CECC, which attracted the kind of work normally associated with cultural studies. The meeting was entitled 'Current Debates in English and American Studies' and took place in 12-14 May 2011, at the Faculty of Arts and Humanities of the University of Coimbra. For the programme, see:

http://www.apeaa.uevora.pt/Final_Program_32APEAA_3.5.pdf (accessed 17 May 2011). For the call for papers, see http://www.apeaa.uevora.pt/ (accessed 17/05/2011). For another example of how terminology matters and is an object of negotiation in national contexts, see Chalard-Fillaudeau (2009).

25 Interdisciplinary academic practices proved crucial for the elaboration of some of these critiques. Sanches' article, for instance, was built from within German studies, but published in Etnográfica, one of the major Portuguese anthropological journals.

26 Mikko Lehtonen also raised this problem at the Current Issues in European Cultural Studies Conference.

27 This understanding of cultural studies (as requiring reading skills, the acknowledgment of complexity and the examination of context) has been guiding my practice, even when dealing 
with literary texts, which - following Lawrence Grossberg's theoretical proposal (2010: 26; 66; 203) - I take to be an entrance point into a specific conjuncture rather than the object of my research. Hence, more than an exercise in literary criticism, my take on E.M. Forster's Italian novels (Sampaio 2012) aims ultimately at describing the specific conjuncture that assembled certain tourist practices and the political and literary culture of liberalism in Edwardian England, the main elements of which continue to be active in our days.

\section{References}

Almeida, Sónia Vespeira de (2009): Camponeses, Cultura e Revolução: Campanhas de Dinamização Cultural e Acção Cívica do M.F.A. (1974-1975), Lisboa: Edições Colibri and IELT.

Bal, Mieke (2000): 'Crossroads Theory and Travelling Concepts: From Cultural Studies to Cultural Analysis’, Jan Baetens \& José Lambert (eds): The Futures of Cultural Studies: Essays in Honour of Joris Vlasselaers, Leuven: Leuven University Press, 3-21.

Baptista, Maria Manuel (2009): 'Estudos Culturais: O quê e o como da Investigação’, Carnets, Cultures littéraires: nouvelles performances et développement, no. spécial, automne / hiver, 451-461: http://revistas.ua.pt/index.php/Carnets/article/view/466/422 (accessed 20 September 2012).

Bourdieu, Pierre (1995/2000): 'Passport to Duke', Loïc Wacquant (trans), Nicholas Brown and Imre Szeman (eds): Pierre Bourdieu: Fieldwork in Culture, Lanham, MD/ Boulder/ New York/ Oxford: Rowman \& Littlefield, 241-46.

Chalard-Fillaudeau, Anne (2009): 'From Cultural Studies to Études Culturelles, Études de la Culture, and Sciences de la Culture in France', Cultural Studies, 23:5-6, 831-854.

Cerwonka, Allaine (2009): 'Higher Education "Reform”, Hegemony, and Neo-Cold War Ideology’, Cultural Studies, 23:5-6, 720-735.

Cornut-Gentille D’Arcy, Chantal (2009): ‘”A Room of One’s Own”? Cultural Studies’ Relationship to Institutionalization and Disciplinarity in Spain', Cultural Studies, 23:5-6, 855-872.

Fornäs, Johan (1999): 'Advancing Cultural Studies in Sweden: The ACSIS proposal', Statement for the international workshop 'Advancing Cultural Studies' at Södergarn Conference Centre, Lidingö near Stockholm, 4-4 February, 123-158: http://www.isak.liu.se/acsis/publikasjoner/1.91935/acsreport1999.pdf (accessed 20 September 2012).

Garnham, Nicholas (2005): 'From Cultural to Creative Industries: An Analysis of the Implications of the "Creative Industries" Approach to Arts and Media Policy Making in the United Kingdom', International Journal of Cultural Policy, 11:1, 15-29.

Grossberg, Lawrence (2006): 'Does Cultural Studies have Futures? (Or What's the Matter with New York?): Cultural Studies, Contexts and Conjunctures’, Cultural Studies, 20:1, 1-32.

------ (2010): Cultural Studies in the Future Tense, Durham and London: Duke University Press.

KEA, European Affairs (2006): The Economy of Culture in Europe, Study Prepared for the European Commission (Directorate-General for Education and Culture): http://www.keanet.eu/ecoculture/studynew.pdf (accessed 20 September 2012).

Mateus, Augusto \& Associados (2010): O Sector Cultural e Criativo em Portugal - Relatório Final, Estudo para o Ministério da Cultura (Gabinete de Planeamento, Estratégia, Avaliação e Relações Internacionais): http://www.mincultura.gov.pt/SiteCollectionDocuments/Imprensa/SCC.pdf (accessed 20 September 2012).

Miller, Toby (2004): 'A View from a Fossil: The New Economy, Creativity and Consumption Two or Three Things I don’t Believe in', International Journal of Cultural Studies, 7:1, 55-65. Miller, Toby \& George Yúdice (2002): Cultural Policy, London/ Thousand Oaks: Sage. 
Mulhern, Francis (2000): Culture/ Metaculture, London and New York: Routledge.

Oakley, Kate (2004): 'Not so Cool Britannia: The Role of the Creative Industries in Economic Development', International Journal of Cultural Studies, 7:1, 67-77.

Pina, Álvaro (1999): 'Making Contexts Visible', Cultstud-L: http://www.cas.usf.edu/communication/rodman/cultstud/columns/ap-08-08-99.html (no longer accessible).

----- (2000): 'Teaching and Doing Cultural Studies in Portugal', Cultstud-L: http://www.cas.usf.edu/communication/rodman/cultstud/columns/ap-30-01-00.html (no longer accessible).

------ (2003): 'Intellectual Spaces of Practice and Hope: Power and Culture in Portugal from the 1940s to the Present', Cultural Studies, 17:6, 751-766.

Ribeiro Sanches, Manuela (1999): 'Nas Margens: Os Estudos Culturais e o Assalto às Fronteiras Académicas e Disciplinares’, Etnográfica, III:1, 193-21: http://ceas.iscte.pt/etnografica/docs/vol_03/N1/Vol_iii_N1_193-210.pdf (accessed 14 May2011).

Ross, Andrew (2009): Nice Work if you can get it: Life and Labor in Precarious Times, New York and London: New York University Press.

Sampaio, Sofia (2012): “I Wish Something Would Happen to You, My Friend!” Tourism and Liberalism in E.M. Forster's Italian Novels’, Textual Practice, 26:5, 895-920.

Silva, Maria João Ramos da (2012): Mason \& Barry e a Construção da Mina De São Domingos: Indústria, Turismo, Globalização, Lisboa: Faculdade de Letras da Universidade de Lisboa (unpublished PhD Thesis).

Silvestre, Osvaldo (1999): 'Caminhos Que Se Bifurcam: Estudos Literários Ou Estudos Culturais?’, Ciberkiosk: http://www.uc.pt/ciberkiosk (no longer available). 


\title{
"Something is at Stake": Northern European Cultural Studies Where, How, and Why?
}

\author{
By Anne Scott Sørensen
}

\begin{abstract}
In this article, I address the current state of cultural studies in Northern Europe and more specifically in the Nordic countries, especially in Denmark. I take my point of departure in offering an answer to the question, what is cultural studies anyhow? and raise some questions about its future directions. From that, I then discuss how we can reason about regional cultural studies since in so doing we are caught in a dilemma: on the one hand, it provides a way to nuance hegemonic histories and ways of mapping the international field but, on the other hand, it also inevitably leads to new generalizations and new inclusions and exclusions. I go on to examine first the (im)possibility of scaling (regional, national, etc.) and, next, the challenge it raises at different levels of setting, i.e., Northern Europe, the Nordic countries, and Denmark. Finally, I focus on national, i.e., Danish cultural studies and return to the question of the future of the discipline.
\end{abstract}

Keywords: Cultural studies, Scandinavian cultural studies, regional cultural studies, cultural forms, the performative turn, ciritique and ethics. 


\section{"Wrestling with the Angles"}

"Wrestling with the angels" is a metaphor introduced by Stuart Hall, director of the Centre for Contemporary Cultural Studies at Birmingham University from 1969 to 1979, in an article entitled "Cultural Studies and Its Theoretical Legacies” from 1992. The metaphor is complex since it refers to the ambition to deliver a critique of power in society and academia but also the ambition to keep cultural studies dynamic and open to both external and internal critique. The metaphor articulates how cultural studies operates in the dilemma of being "noisy," at one and the same time contesting and contested.

Since 1992, cultural studies has struggled to match the new world order in the wake of the fall of communism in Eastern Europe; the rise of new global tensions and agendas, signified by 9/11 (2001) and the war on terror; and a general crisis of the New Left in western societies that had spawned cultural studies. Power has been much more complicated to identify as well as "the common good" as phrased by another key figure in cultural studies, Raymond Williams. This is because local and global challenges are intermingled in new and complex ways, and the social movements that may provide future solutions are diverse and split. However, the renewed global focus on culture and the obvious need to transgress rigid academic disciplines have also put cultural studies at the center of the humanities and the social sciences since it has been interdisciplinary from the beginning. It might even be argued that cultural studies, in some parts of the academic world, constitutes the new general study. Today, cultural studies has spread geographically, been mingled into still more disciplines, and multiplied into a range of subfields. The crisis has been mirrored by the success, which again - paradoxically - has caused a state of diffusion, the more so since cultural studies, from the outset, has resisted being a fixed and institutionalized discipline.

The question of regional cultural studies can only reinforce this dilemma since it witnesses both the success and the diffusion. Furthermore, regional cultural studies, be it defined as, for instance, North European, Nordic, or Danish, is captured in the paradox of scaling in the era of globalization (Herod 2011) and in the dilemma of being cultural studies in as well as of a given region - tending to construct the region that it is supposed to have found "out there." This is what happened to cultural studies in Britain at least, when it gradually turned into cultural studies of the British and came to rectify at the same time as it criticized. This article discusses these challenges and especially the interrelatedness of the struggle of cultural studies in general and of its North-European or Nordic or Danish appearance in particular. But let me begin by asking: 


\section{"What is Cultural Studies Anyway"?}

The subtitle of this section echoes another paradigmatic article in cultural studies, written by Richard Johnson (1987). He raises the question, admitting that cultural studies is a noisy academic field in the sense that it is defined not as much by a distinct object since culture is a polysemic term, as by its approach, namely, that of cultural critique, claiming the role of society's "watchdog," always snapping at the heels of institutions and structures of power. Cultural studies is thus said to be distinguished by asking questions, such as: what is done with culture, by whom, and for what purposes? Still, the article can also be read as a kind of self-critical reflection on, on the one hand, the legacy of (structural) Marxism due to the pitfalls of reducing culture to society, and, on the other hand, the legacy of the (thenstill) new wave of post-structuralism due to the inherent risk of reducing society and politics to culture.

Johnson's way is to ask for the specific inquiry of cultural studies, namely, the inquiry as to the forms of social life or rather the subjective forms of social life and the time-space constellations they enact and, not least, the inherent pressures or tendencies by which they move us, their force (Johnson 87: 66). According to Johnson, such forms are dynamic and almost impossible to grasp as such, but they can be deduced in their tendency through an analysis of the circuit of culture: from production through distribution to consumption and new production, etc. This circuit of culture is, Johnson argues, again stretched between, on the one hand, the universal or abstract vis-à-vis the singular or concrete and, on the other hand, the public (display) vis-à-vis the private (lives).

Johnson's key example (1986/87) is the Mini-Metro car, produced by British Leyland in the 1980s, which was meant to rescue the British car industry (and economy). It was designed, marketed, and, in the end, also consumed as a national hero to conquer external enemies (industrial competitors) as well as internal critics (the workers' union and the communists) in postwar Britain by bringing new periods of welfare to the British working- as well as (lower-) middle-class families. And it brought new opportunities for dual-working families and their children in terms of mobility and flexibility whilst making them partners in the postwar consumer project. Power and empowerment were intertwined in the consumer society under construction, so distinctively manifested in "the nationalist sell" of the Mini-Metro, which, both literally and symbolically speaking, was meant to push foreign cars over the cliffs of Dover into the Channel. This image-thing was both a representation of postwar Britain and an effective presentation hereof.

By offering a reading of contemporary culture in one's own cultural context, much the same way as anthropologists had approached distant, exotic cultures, and at the same time focusing on the ordinary and the everyday instead of the exclusive or the deviant, cultural studies constituted an alternative to anthropology, sociology, and art history. And by introducing the circuit of culture, Johnson and 
the Birmingham School also distanced themselves from their forerunners at the Frankfurt School and the former tradition of critical theory. Contrary to, in particular, Adorno, the Birmingham School was interested in consumption not only as a mass phenomenon and a prerequisite for formal production (be it industrial or artistic) - but as a sort of distributed, productive practice in itself. Johnson, in his article from 1986/87, reminds of Lukács' analysis of the British brewer's slogan "What we want is Watneys," which, in its critique of the commercial for turning consumers into passive dupes of consumption, misses out on the multiple enjoyments and social practices involved in both beer drinking and slogan speaking. The analysis grasps the direction of power, but not the empowerment, according to Johnson.

In their rereading of the Frankfurt School Lash and Lury (2007) discuss the notion of power in Adorno's work in terms of a relation between "potesta" and "pontensa," which they now interpret as a tension between being (having had the power to become) and becoming (having the potential to become). From this revision of the issue of power, they analyze a range of examples from the new global culture industries (from Toy Story to Nike) that they call virtuals: image-things consumers can both relate to and interact with in multiple ways within the framing of the brand. The possibility of critique, then, lies in identifying what cannot come into existence within such a framing in terms of the common or public good or new forms of life. Thereby, critique itself has changed from a more political to a more ethical stand, as also suggested by, for instance, Bal (2002), Zylinska (2005), and Couldry (2010). I shall return to that at the end regarding the implications of the performative turn in cultural studies, the way this turn has been translated in Danish research.

\section{Transnational Cultural Studies}

Talking about cultural studies almost inevitably leads to critical theory as it was renewed by the Frankfurt School and this again critically revised by the Birmingham School etc. However, in the last decades, this history of origin and the subsequent establishment of a certain (north)western canon have been counteracted by a range of scholars, not least from non-(north)western regions, and accused of echoing an all-too-well-known narrative of, in this case, academic hegemony (Morley \& Chen 1996; Stratton \& Ang 1996; Chen 1998). Stratton and Ang, for instance, do not accept the story of influence that says that it all started in a European center and from there spread via the West (the United States, Canada, Australia, etc.) to the rest (the former communist East, Southeast Asia, etc.). They claim such a story of influence characterizes the same hierarchies that signify global economic, political, and cultural development and it is important to rewrite it as such a story, along with telling other stories of the disseminated and maybe strange cultural studies. 
Since then, many such stories have been brought to the global public, for instance, Trajectories: Inter-Asia Cultural Studies (1998). They have again raised questions about new as well as old structures of center-periphery and possible reifications of the latter in terms of regional identities - for example, Asia today is a highly differentiated region and the very notion Asian is accordingly diverse. The subaltern is not, and never has been, one. Chen, the editor, acknowledges this and calls for a critical internationalism or syncretism by which each agent takes a geopolitical position, respecting that it is relative to that of other(s) and always in itself inherited in a complex global game of power, knowledge, and scaling (Chen 1998). At the same time, he insists that nonwestern regions can and should benefit from broad coalitions and provisional standings, such as the Inter-Asian in cultural studies and elsewhere.

Implied in the center-periphery discussion of influence and eventual dialogue is the delicate question of language. The academic monopoly of the English language worldwide - and not least in Asia - only seems to grow proportionally with the overall academic field. The situation constitutes a very principal, political as well as very concrete, practical problem at international conferences (Crossroads), in journals, and in publishing at all. And it is a condition shared by nonwestern as well as western countries, for instance, the Nordic countries (for a thorough discussion of the consequences not only for researchers and research but also for the very production of knowledge, see Alasuutari 2004; Fornäs \& Lehtonen 2005). There are no easy answers to this challenge, and whereas cultural studies in English is spread all over the world, cultural studies from non-English-speaking countries and in other languages has to either be translated into English, or accept its desolation and absence from international dialogue.

Its upside is that cultural studies in English provides a common point of reference in a situation of general diffusion. From the very start, cultural studies has resisted institutionalization in the sense that it has refused to be boxed in a fixed discipline and insisted on an interdisciplinary approach. Throughout the twentieth century, cultural studies has instead spread to anthropology, sociology, and more so in terms of new disciplinary "halfies," such as cultural anthropology, cultural sociology. In the twenty-first century, the process has continued due to a general dual process of disciplinary differentiation and integration, caused by the new "flexible" and modularized research and education system - in Europe reinforced by the mainstreaming of research and higher education within the European Union and the general wave of New Public Management.

Simultaneously, cultural studies has multiplied into a range of sub-studies, in the beginning, for instance, gender, youth, gay, and race and ethnic studies, and later on, for example, (sub)urban studies, mobility studies, studies in visual and material culture, and in experience design. This internal differentiation has continued and been intensified by regular theoretical turns: from structuralism to post-structuralism, and as already predicted by Johnson (1987), a post-post- 
structuralism. Each of these bigger turns has made an epoch (differently so in various regions and institutions), with each having their minor moments that again have introduced new objects or foci. The post-poststructuralist turn has since been rephrased as the performative turn and as "that which does or makes things happen in the moment of naming” (Sørensen et al. 2010), which signals a research interest in the material, spatial, and sensual or emotional that has followed the linguistic or semiotic focus of post-structuralism.

\section{Northern Europe, the Nordic Countries, or Scandinavia?}

The first question that arises is: what is Northern Europe or the Nordic countries? The answer depends on the premise of scaling: geographic, economic, political, historical, or linguistic? In Signifying Europe, Fornäs (2011) has discussed the paradox implied in either of these and consequently the impossibility of fundamentally defining (regions of) Europe. Instead, he suggests examining the symbols used to represent Europe and Europeanness, both inside and outside Europe and at different levels. Since scaling is nevertheless also impossible to avoid, I will, in the following, introduce the common ways of distinguishing (parts of) Northern Europe and the inherent dilemmas (see also Eskola \& Vainikkala 1994). Northern Europe would, in the broadest sense of the term, include parts of Germany, France, the British Isles, the Netherlands, and maybe even parts of Poland and Russia. The narrower term would include the Nordic countries, and this would again in a rather broad sense mean Denmark, Norway, Sweden, Finland, as well as the Baltic states (Estonia, Latvia, and Lithuania), besides Greenland, Iceland, the Faroe Islands, and the Åland Islands. A tighter definition of the Nordic countries would exclude the Baltic states. A narrower term would be Scandinavia, which again would refer to the historical and cultural entity of the kingdoms of Denmark, Norway, and Sweden (with closely related Germanic languages as opposed to, in this case, Finnic), in others to the geographical peninsulas of Denmark, Norway, and Sweden. It would, in principle, not include Greenland and Finland even if it is often done in practice nowadays, whereas it would (most often) include the Faroe Islands and Iceland. ${ }^{1}$ Yet another definition would refer to the shared roots in the pre-Christian Norse (mythology) and the Viking era, but, then again, it would widen to include at least northern Germany.

If we take the term the Nordic countries as a point of departure, and define them as minus the Baltic states, there are still major differences already in terms of acting on the European and international political, economic, and military stage: whereas Norway is outside the EU, Sweden and Finland are not members of NATO. On the other hand, there is an extensive social, cultural, and academic exchange through the Nordic Council, the Nordic Culture Fund, and the research organization Nordforsk respectively, including, for example, the Nordic Centre of Excellence Programme on Welfare Research. The center conducts research on the 
historical evolution of the Nordic welfare model and its ability to adapt to changing external circumstances as well as handle the internal pressure on welfare rights and institutions (2007-2012). The Nordic countries are often seen as, and understand themselves as, a political as well as cultural entity due to the way they are associated with their particular formation of the welfare state and society in terms of extended social rights; differentiated democratic institutions, not least in terms of public education; and considerable freedom of speech. In this sense, they are distinguished as the hallmark of Europe as well. But the Nordic countries are also considered, and consider themselves, to be on the periphery of Europe (and the world) due to their geographical remoteness, relatively small populations and economies, and comparatively minor languages (cf. Fornäs \& Lehtonen 2005).

Accordingly, the Nordic countries share the paradox of being both at the center and on the periphery and being split into a number of internal centers and peripheries. The southern parts of the Nordic countries have up till now benefited from their closeness to central Europe, whereas the northern parts have suffered due to the distance and, instead, looked to the British Isles or the American continent. At the same time, the distances between the center and the periphery within each country have grown - potentially fatiguing, for instance, northern Norway, northern Sweden, and northern Finland, not to mention Greenland (formerly a Danish province, but now an autonomous community that is part of the Kingdom of Denmark) and thereby also minorities, such as the Sami and the Inuit. However, globalization, in combination with digitalization, is changing the power balances of modernity, for example, by making both northern Norway and Greenland members of the Arctic (the polar region consisting of the Arctic Ocean and parts of Canada, Russia, Greenland, Norway, the United States, Sweden, Finland, and Iceland). This region is, in terms of natural resources, global infrastructures, and military interests, becoming increasingly important to international politics and the global economy, and along with the conscious positioning as such, the (economic, political, and cultural) rights of the region's minorities are more forcefully put on the agenda.

\section{Cultural Studies in and of the North}

We do not - yet? - have an anthology on cultural studies in the Nordic countries or Scandinavia that corresponds to, for instance, Trajectories (1998). One explanation might be the dilemma of regional cultural studies: criticisms of British cultural studies have pointed out how it tended to be studies of the regional that both rectified and identified. Another explanation might be that cultural studies has developed differently in the various Nordic countries (for a thorough discussion of the disciplinary crossroads in each country, see Eskola \& Vainikkala 1994). What we have instead is a number of introductions to the field, each with their accentuations since the 1980s, and lately also an overall introduction to the theories and 
themes of cultural studies, published in Norwegian and Danish (Sørensen et al. 2010). In addition, this publication includes an introduction that maps the rather different pathways cultural studies has taken in the Nordic countries as well as the many contributions from Nordic researchers to international cultural studies (Alasuutari 1995; Fornäs 1995; Lehtonen 2000; Schröder et al. 2003).

As argued here, cultural studies has, since the early 1980s, established a rather strong research agenda in Sweden, Finland, Denmark, and Norway, initially studying youth cultures, and with a common resource, namely, the journal Young: Nordic Journal of Youth Research (now with a more sociological profile). Today, the national research center ACSIS in Sweden constitutes a resource for cultural studies throughout the Nordic countries, including the biennial conferences and the e-journal Culture Unbound. Finland has a national association of cultural studies, and along with Denmark and Norway, it has a journal in its own language to do with the broader field of interdisciplinary cultural research. In all the Nordic countries, there is also a range of courses in cultural studies, whereas study programs and departments are established according to the broader field of transdisciplinary studies of culture (often also within an even-broader umbrella, including, for instance, art, communication and/or media). In all the Nordic countries, the maxim has come true, namely, that cultural studies has influenced research agendas more than institutions. In each of the Nordic countries, the critical tradition is very much alive in research, now most often in combination with more local research traditions. In Sweden, there has been a particularly fruitful convergence with ethnology and ethnography, in Finland with sociology and political science, in Denmark with literary and media studies, and in Norway with anthropology and cultural policy studies. Up till now, only Sweden has a publication on national cultural studies, in which these particular convergences between international cultural studies and local academic research agendas are addressed more systematically (Axelsson \& Fornäs 2007).

Due to the historically close cultural relations between the Nordic countries, Scandinavian studies has been established worldwide as an interdisciplinary academic field of area studies that covers topics related to Scandinavia and the Nordic countries, including their languages, literature, history, culture, and society. The field of Scandinavian studies, typically but not always (for instance, not in German "Skandinavistik"), adopts the broader definition to include Finland and the Finnish language. The tradition of Scandinavian area studies is very similar to what in Germany and other countries is called "Kulturwissenschaften" and as such they form a distinct tradition extremely different from, but sometimes also engaged in, cultural studies to the extent that they integrate critical theory and cultural critique. Along with the general academic epoch of post-structuralism and deconstruction, not only Scandinavian studies but also area studies in general have fertilized a self-reflective position as to the co-construction of the region they study. Nordic literature and culture have also been features of collaborative Nor- 
dic research projects related to, among others, feminist studies, media studies, and literary studies (see, for example, Povlsen 2007). In the last-mentioned, research in the Nordic countries has, moreover, been research on the construction of "the Nordic" or "the North" from cultural studies-related perspectives even if it has not been the only and primary agenda.

\section{Danish Cultural Studies}

The closest we have come to a national organization for cultural studies in Denmark is a national network for cultural research and analysis, funded by the Danish Council for Independent Research | The Humanities (2003-2006), which published a series of four books in Danish. The series provided a broad overview of cultural studies-related research in Denmark at the beginning of the millennium, organized in four thematic subjects that mark the actual epoch and its moments: cultural critique and art criticism, cultural diversity and multiculturalism, space and material culture, cultures of taste, and cultural mediation (Bech \& Sørensen 2005; Povlsen \& Sørensen 2005; Erikson, Jantzen, Madsen, \& Sørensen 2006; Sørensen \& Zerlang 2006).

In Denmark, we have no "proper” cultural studies research center, but a range of university departments and academic milieus engaged in the discipline. Both in terms of research and education, they have positioned themselves vis-à-vis each other and each has adopted a profile. At the University of Copenhagen and Aarhus University respectively (the old and established universities), there has been a strong affiliation with the arts and art criticism and an intellectual engagement in, on the one hand, the Frankfurt School, and, on the other hand, a local tradition called "kulturradikalisme" (cultural radicalism). It is a modernist and reformist tradition very similar to the critique voiced by the Frankfurt School, but has artists, writers, and cultural critics (intellectuals) at the forefront and engaged in public debates on literacy, sexuality, architecture and design, and pedagogy. At the University of Southern Denmark (main campus in Odense), the affiliations have been somewhat different and more at home with the Birmingham School in combination with another local tradition of cultural critique, stemming from broader social and educationalist movements and "classic" social democracy. Within this tradition, the word "folkeoplysning” (public education) means self-education by the people. At the new universities, Roskilde and Aalborg universities respectively, cultural studies-related activities have been involved in, on the one hand, migration and minority issues, and, on the other hand, the new experience economy. Other relevant agents today are Copenhagen Business School and the IT University of Copenhagen due to their massive appeal to academics educated in cultural studies and now engaged in cultural enterprises in a broad sense. Titles, such as Design as IT, Art \& Technology, Experience Economy, Performance Design, etc., indicate a new horizon, a revitalized field of culture studies that is not only an 
umbrella for different disciplinary approaches but comes together with the aim of engaging in aesthetic and cultural transformation.

Since trying to give an overall survey of Danish cultural studies would be impossible and selecting a sample of outstanding work would be subjective and unfair, I shall only briefly mention some directions I see the discipline taking, and provide a single, hopefully illustrative, example hereof. In his article from 1986/87, Johnson outlined the circuit of culture as the object of cultural studies. He also warned against paying too much attention to either the productive or the consumptive end of the cultural circuit since it has to be seen as a continuum. He further advised focusing on forms since they not only mirror but also act as the force of their time-space. A number of scholars and research groups have since then taken this turn to performance and performativity further, for instance, the Amsterdam School for Cultural Analysis (ASCA), initially founded by Mieke Bal, and an inspiration to many research milieus in Denmark. Whereas it has often been claimed that Bal, through her critique of cultural studies, positions herself outside the tradition, she has here been seen to take the position of an engaged dialogue (Sørensen et al. 2010). In Travelling Concepts in the Humanities (2002), Bal suggests cultural studies be repositioned as cultural analysis, taking the analysis of dynamic aesthetic objects in their cultural embedding and operation as their agenda. She further addresses the concept of performance along with other significant traveling concepts or rather the dual concept of performance and performativity, which is said to be found in art and culture as well as critique and research. Whereas performance signifies a distilled form of cultural expression, most often framed as art, performativity denotes the way it, as a popular subjective form, is cited, circulated, and negotiated - assembling the kind of time-space form Johnson is looking for. Only, Bal's point is about engagement and ethics rather than critique from a range of positions, such as citizen, artist, and researcher.

The dual concept of performance and performativity is addressed by a number of Nordic scholars too, also in international publications (Gade \& Jerslev 2005; Jansson \& Lagerkvist 2009; Knudsen \& Waade 2009). Further, studies like these have been inspired by post-structuralists, such as Michel Foucault and Judith Butler, but have also discussed the traditions of ethnomethodology, microsociology, and actor-network theory as well as studies on body and space, emotionality, affect, and mobility. In this sense, they have brought both agency and materiality (or rather sensuality) back into cultural studies and enhanced a (new) focus on cultural "realness" or "liveliness." Another source of inspiration has been posthumanism and, in particular, the human geographers Hayden Lorrimer (2005) and Nigel Thrift (2007), who have introduced the concepts of non- and more-thanrepresentational theory respectively, the point of both being to study life and life processes rather than meanings or representations.

In Nye kulturstudier [Cultural Studies] (2010]), the authors give an example from Denmark to illustrate the epoch of performativity as a cultural mode and 
more-than-representation as a research agenda, namely, the Danish-Sudanese reggae artist and rapper Natasja and her song (and video) "Gi' mig Danmark tilbage” [Give Denmark Back to Me], from her CD I Danmark er jeg født [I Am Born in Denmark] (2007). The CD came out the same year she died in a violent car crash in Jamaica, where she had just won the big rap contest and was about to make her national as well as international breakthrough. In this song, she mimics Danish cultural traditions, from the Christian founder of the folk high school movement, F. S. Grundtvig, to the fairy-tale writer H. C. Andersen, both from the nineteenth century, to the heirs of twentieth-century cultural radicalism as well as the "true" social democrats of the twenty-first century, namely, the proponents of the free city of Christiania as well as the youth center "Ungeren." The implicit reference point of the song (and video) is a campaign by the (right-wing) Danish People's Party (a party founded in the 1980s) against immigration and immigrants. In the song, Natasja plays with the paradox that with her mixed background, she is the one to reclaim the "real" Denmark of liberalness and fairness and wrestle it out of the hands of neo-conservatism and a general moral and political backlash, including an inherent romanticized vision of national origin and authenticity. However, the performative effect stems not so much from the words and the specific references or even from the alternatives but rather from the energetic display of music, dance, visuals, and words that displays the atmosphere and free spirit of the country and nation that Denmark and the Danish would be. ${ }^{2}$ As the song and video go on, old as well as new stereotypes are grasped with, engaging the listener or critic in the ambiguous process of culturally becoming.

\section{Conclusion and Perspectives}

The aim of this article has been to argue about the paradox of, on the one hand, the impossibility of defining national or regional cultural studies as well as the overall field of cultural studies, and, on the other hand, the necessity (and unavoidability) to do so in order to fight for an academic position at different levels from which to gain recognition and thereby the resources to keep the project alive and well. Critical theory, like cultural studies, has, from the mid-twentieth century on, constituted a dynamic center for trans-disciplinary cultural research, and has also been able to self-transform in a more vital, ethical, and active direction. Today, the project seems to have run out of steam, at least in the Nordic countries, notably due to its own resistance to institutionalization as well as its extreme reflectivity to the co-construction of the lifeworld it engages with. But my claim is that we still need cultural studies to go on exploring the possibilities of - and eventually the differences between - inter- and trans-disciplinarity and, based on this, produce studies focusing on how life takes shape and gains expression (Lorrimer 2005) in multiple and dynamic relations, experiences, and practices, insist- 
ing that knowledge is not universal, objective, etc., but inter-subjective, processual - and performative.

Anne Scott Sørensen, Ph.d. and associate professor, Institute for The Study of Culture, The Culture and Communication Section, University of Southern Denmark. Has written extensively on these subjects, for example a reader in cultural studies in Norwegian (2008) and in Danish (2010). Has directed a national network in Cultural Research and Analysis and been main editor of the network serial of four publications (2005-2006). E-mail: annescott@sdu.dk

\section{Notes}

$1 \quad$ For an in-depth historical discussion in English, see U. Østergaard: "The Geopolitics of Nordic Identity: From Composite States to Nation States”, http://diis.dk/graphics/CVer/Personlige_CVer/ Holocaust_and_Genocide/Publikationer/uffe_new_nordic.pdf.

2 Natasja: “Gi’ mig Danmark tilbage” [Give Denmark Back to Me), I Danmark er jeg født [I Am Born in Denmark], http://www.youtube.com/watch?v=NONnUBKcNZI.

\section{References}

Alasuutari, Pertti (1995): Researching Culture: Qualitative Method and Cultural Studies, New York: Sage.

------ (2004): “The Globalization of Qualitative Research”, Clive Seale, Giampietro Gobo, Jaber F. Gubrium; David Silverman (eds):Qualitative Research Practice, London: Sage, 595-608.

Axelsson, Bodil \& Johan Fornäs (eds) (2007): Kulturstudier i Sverige [Cultural Studies in Sweden], Stockholm: Studentlitteratur.

Bal, Mieke (2002): Travelling Concepts in the Humanities, Toronto: University of Toronto Press.

Bech, Henning \& Anne S. Sørensen (eds) (2005): Kultur på kryds og tvœrs [Cultural Intersections], Aarhus: Klim.

Chen, Kuan-hsing (ed.) (1998): “Introduction: The Decolonization Question”, K-H. Chen (ed.): Trajectories: Inter-Asia Cultural Studies, New York: Routledge.

Couldry, Nick (2010): Why Voice Matters, New York: Sage.

Eskola, Katarina \& Errki Vainikkala (1994): “Nordic Cultural Studies - An Introduction”, Cultural Studies, 8:2, 191-197.

Eriksson, Birgit, Christian Jantzen, Karen H. Madsen \& Anne S. Sørensen (eds) (2006): Smagskulturer og formidlingsformer [Cultures of Taste and Cultural Mediations], Aarhus: Klim.

Fornäs, Johan (1995): Cultural Theory and Late Modernity, New York: Sage.

----- (2011): Signifying Europe, Bristol: Intellect Press.

Fornäs, Johan \& Mikko Lehtonen (2005): "Between Centres and Peripheries in Transnational Cultural Studies”, U. T. Kovola et al.: Erkki Vainikkala’s Festschrift, http://www.arthis.jyu.fi/julkaisut/tarkkojasiirtoja/lehtonenfornas.html. (accessed 27 February 2013). 
Gade, Rune \& Anne Jerslev (eds) (2005): Performative Realism: Interdisciplinary Studies in Art and Media, Copenhagen: Museum Tusculanum Press.

Hall, Stuart (1992): “Cultural Studies and Its Theoretical Legacies”, Grossberg, Lawrence, Cary Nelson, \& Paula Treichler (eds): Cultural Studies, New York: Routledge.

Herod, Andrew (2011): Scale (Key Concepts in Geography), New York: Routledge.

Jansson, André \& Amanda Lagerkvist (eds) (2009): Strange Spaces: Explorations into Mediated Obscurity, London: Ashgate.

Johnson, Richard ([1983] 1986/87): “What Is Cultural Studies Anyway”, Social Text, 16, 38-80.

Knudsen, Britta T. \& Anne Marit Waade (eds) (2010): Re-Investing Authenticity: Tourism, Place and Emotions, Bristol: Channel View Publications.

Lash, Scott \& Celia Lury (2007): Global Culture Industries, Cambridge: Polity Press.

Lehtonen, Mikko (2000): The Cultural Analysis of Texts, New York: Sage.

Lorrimer, Hayden (2005): "Cultural Geography: The Busyness of Being 'More-ThanRepresentational'”, Progress in Human Geography, 29, 83-94.

Morley, David \& Kuan-hsing Chen (eds) (1996): Stuart Hall: Critical Dialogues in Cultural Studies, New York: Routledge.

Povlsen, Karen K. (2007): Northbound: Travels, Encounters and Constructions, 1780-1830, Aarhus: Aarhus University Press.

Povlsen, Karen K. \& Anne S. Sørensen (eds) (2005): Kunstkritik og kulturkamp [Art Criticism and Culture Wars], Aarhus: Klim.

Schröder, Kim, Kirsten Drotner, Stephan Kline, \& Catherine Murray (eds) (2003): Researching Audiences, London: Arnold Publishers.

Sørensen, Anne S. \& Martin Zerlang (eds) (2006): Kultur uden centre [De-centered Culture], Aarhus: Klim.

Sørensen, Anne S., Ole Martin Høystad, Erling Bjurström, \& Halvard Vike (2010): Nye kulturstudier: Teorier og temaer [Cultural Studies: Theories and Themes], Copenhagen: Tiderne Skifter. (Extended and revised edition of Nye kulturstudier [Cultural Studies], Oslo: Spartacus, 2008).

Stratton, John \& Ien Ang (1996): “On the Impossibility of a Global Cultural Studies: British Cultural Studies in an International Frame”, David Morley \& Kuan-Hsing Chen (eds): Stuart Hall: Critical Dialogues in Cultural Studies, New York: Routledge.

Thrift, Nigel (2007): Non-treprensentational Theory: Space, Politics, Affect, London: Taylor \& Francis.

Zylinska, Joanna (2005): The Ethics of Cultural Studies, New York: Continuum. 



\title{
The Boratization Revisited: Thinking the "South" in European Cultural Studies
}

\author{
By Aljoša Pužar
}

\begin{abstract}
The intention of the essay is to try to understand the broader cultural conditions that surround the articulations of cultural studies in South-European Academia, but also to address the apparent ethical and political irrelevance of those articulations. A catalyst of this discussion is the author's ongoing dissatisfaction with the widespread cultural studies activities in the South being mostly part of the corporatization and westernization of Southern universities, which are increasingly distant from their much needed ethico-political public mission in times of struggling democracies and crumbling welfare states. In the attempt to propose a viable framework for the necessary future reform of the anti-discipline, three different aspects are discussed as both indicative and instrumental: the ambivalent notion and destiny of Southern "citizenship" (as the politically and legally articulated aspect of a daily performed subjectivity and belonging), the phenomenon of the eliteless transitions (including the shifts in the Southern critical public), and the role of the academic and political Marxism (including its gradual dissolution or suppression).
\end{abstract}

Keywords: Cultural studies, South Europe, politicality, citizenship, transition, marxism. 
Kennst du das Land, wo die Zitronen blühn, / Im dunklen Laub die Gold-Orangen glühn, / Ein sanfter Wind vom blauen Himmel weht, / Die Myrte still und hoch der Lorbeer steht, / Kennst du es wohl? / Dahin! Dahin / Möcht ich mit dir, o mein Geliebter, ziehn. (...)

(Johann Wolfgang von Goethe)

\section{A Prologue to Bordering}

In July of 2007, during a memorable "Cultural Studies Now" conference at the University of East London, "You are the Borat of this conference!" was a written note pushed into my hand by one of the participants, a man that I superficially knew, seconds after one of my ridiculously passionate discussions that revealed both my strong accent and lack of articles (the lack of). He was from Manchester, if I remember well, whereas I came from Rijeka, Croatia, a city on the border, called Fiume in the Italian language, a river. Instinctively liking his peppery sarcasm, I decided to use his message as the epigraph or motto to my conference paper on the condition of cultural studies in Croatia (Pužar 2007). When I was asked in 2011 to participate in the Norrköping conference that specifically addressed those inter-European conditions and differences, ${ }^{1}$ the same message came handy once again, entailing a specific imagery of spatial differences and the adjacent academic cartographies of power and affects.

Truth be told, I have never seen in its entirety any of the character-based comedies of the English Cambridge-graduated comedian Sacha Baron Cohen, and have never taken upon myself to understand the fine balance between his Jewishness, his Englishness and his political incorrectness, including the anti-Semitic outbursts of the quasi-Kazakhstani Borat. ${ }^{2}$ Being called a Borat of the conference, on the other hand, seemed distressingly familiar.

If I think about it, my portion of "Mitteleurope meeting the Mediterranean" (i.e. the exact paradoxical geographic and cultural crossroads of two ancient "middle earths") was for decades or maybe even centuries perceived as the geopolitical "East"; my personal Italian-Croatian mixture of roots and lived formations could be at times seen as something of an odd match, even an idiosyncratic pose. In the mind of the "real West" (but also among the filtrated images in the Far East and elsewhere), not only Croatia and Italy could be relatively far, but even my town could be far from itself, as far as Kazakhstan is from Baron Cohen's Hammersmith, West London, and it was that same pattern of imagined (mostly political and economic) distances that worked so well even for the Italians and Croatians living in it and around it, in their struggling to prevail in the glocal confrontations of the $20^{\text {th }}$ century. As in the world of the re-imagined places that form dynamically compressed/expanded cartographies of power, the Italian writers from the sister-city of Trieste across the border, and now in Italy, have been writing for centuries already about those tricky desires of the Slavic neighborhood, 
situating the reachable otherness as the ganz andere, envisioning wild explorations, deep muds, smoke-imbued forest edges, a Siberian tundra removed only few miles from the Mediterranean city center. ${ }^{3}$

The evermore convenient bashing of the good old "cosmopolitan-imperial" Englishness aside, the problem of "hazy roots" is always there: from an USA customs officer at Kennedy airport in 1988 looking at my red Yugoslav passport, enunciating slowly, syllable per syllable, and carefully fine-tuning the sarcasm: "Well, well, how's the life in Czechoslovakia these days?", to my Korean colleague kindly asking about the situation back home in Belarus, probably envisioning my frozen childhood winters, and some oversized fur hats that would go alltoo-well with some sort of the Žižekian accent, conveniently emptied of French "theory." A problem here ranges from a simple lack of geographical knowledge to the rudeness, or even the colonial gesture. Once you could be the Borat, constructed, annoying and annoyed, you have half of this world in your portfolio. A very specific half, that is.

Encompassing a legacy of the Cold War, the rhetoric of the Iron Curtain, and tangible geostrategic divisions after Yalta, the Boratization is an old game, producing not only divisions and distances, but also a specific bordering - the already autopoietic process of Border-building, sometimes perceived as a self-standing ethical remedy via the acknowledged and celebrated "hybridity." (Pužar 2013) This essay will think about the deeper reasons for the cultural studies' politicality that aporetically hesitates around those fuzzy borders towards other Europes, those same unspoken borders that, in the mind of a cheerful colleague, moved my place right to his (and everybody's) imaginary Kazakhstan.

\section{Europe's Europes and the Southern "Not Yet"}

If Europe, The Europe, is, as Étienne Balibar reminds us, a "traditional configuration" (Balibar 2004, 2004a), then our argument about the mutual uneasiness of the Southern academia and the intellectual project of cultural studies could be developed also as an argument dependent on the proliferation of specific elusive borders of that configuration, and on the necessary production of Balibar's European "peripheries"-zones that will articulate both myths and historical events of the convenient otherness in conjunction with the traditional configuration of the coreEurope.

Balibar is, of course, right in his view that borders are not to be described as the mere outer limits of territories, but dynamically. There is a specific dispersion of borderworks, following the postindustrial movement of objects, subjects, memes and affects. It seems that, all of a sudden, borderlines seem folded back to the very illusion of the core, a vision akin to the post-structuralist epistemological dualism and nihilism, and, truth be told, dependent on its theoretical tastes. But the broader historicization of such a "new" movement of borders needs to be pre- 
cise too: the Mediterranean cosmopolitan towns, and some of the Northern counterparts, such as Hanzeatic cities, knew for centuries what the monological metropolitan city of the West learned only as its own modernity, with either the imperialistic rise or the post-imperial melt-down. For many people of the South, only the very late modernity carried the novelty of the broader monological forms (such as nationalist and, subsequently, post-nationalist), that can, then, be subverted by the heterotopic idea of constant and inherent bordering (not to say simply: the adding and removing of the contingent identitarian labels to the normal and never-ending articulating and becoming). That specific dissociation in what is imagined as the European temporality (i.e. "the time of Europe") is to be understood as crucial in our assessments of either methodological or organizational models coming from the North-West and being implemented in the apparently dormant Southern academia.

This new and uneasy bordering in between various Europes, based on the specific uneven temporality of the bourgeois nationalist modernity, and the geostrategic legacy of the Cold-War-becoming-War-on-Terror, once interiorized, can be celebrated and conceptualized lucratively as the ethical faculty to embrace the otherness, as the normalized Levinasian vis-à-vis. Still, that celebration always entails the silent and sickening re-confirming of what was abandoned, a melancholic turning back to this or that national matrix spurring and overshadowing the borderworks, and never comes without a disruption of the transnational continuum of intellectual elites and subaltern workforce. After all, whenever those promisingly movable and pointillist new European borders materialize in the South, they usually seem to entail the most detestable ethical and political consequences:

The proposal to establish extraterritorial processing centres and the construction of Italy-funded detention centres on Libyan territory, deportations to and from Libya, and joint Italian-Libyan police patrolling of Libyan coastline are all instances that de-localize the EU's external border from South Italy beyond the Libyan coastline into its territory. They consequently challenge the idea of the EU's external border as a firm border between Italy and Libya and show that southern EU border rather than being a linear and stable geographical demarcation is a discontinuous and porous space encompassing the area between southern Italy and Sub-Saharan Africa. (Andrijasevic 2005: 123)

Even if new borders (Berlin walls turned into apparently soft demarcations of "novelty" and "nostalgia") sometimes produce new multicultural forms and the new hybridity of the pan-European lives (youngsters studying under the Erasmus scheme happily coupling around the continent, forming new intimate trajectories of being European), I wonder if embodying that new kind of hybridity could entail also a certain ethical demand, possibly even some specific ethical faculty.

If one reads what our "grands," names connecting European East and European South with the core Europe, people like Gianni Vattimo and Tzvetan Todorov wrote about the differences in between being American and being European during or immediately after the dark years of the Bush Jr. administration (Todorov 
2005), one can find the fiction of Europeanness presented as an ethical choice, but also almost essentialized into an ethical faculty. Following that logic, one could also ponder over the ethical faculties of the hazy articulation/formation of the European South, seen both as a cradle of Europe, and as the eternal crossroads, a space that is sometimes said to imply certain specific and ancient forms of hybridity and celebrated borderline ethical expectations and potentialities (including "openness," "warmth," "passion," but also "instability," "chaos" or "slowness"). Even without such an unpleasant essentialism and hasty generalizations, one would surely expect from that imagined articulation of the South to be, in Balibar's language, a both tangible and discursively-productive locus of dialectic movements - a place that entails both the problematic encounter with the "stranger" and the communication between "civilizations" (or, for the sake of our argument: a meeting of the different structures of knowledge, different methodologies and pedagogies).

Yet, the problem here is that the historical hybridity of the South was sometimes more a hybridity of attraction and influx, of the old metropolitanism, of De Landa's whirlpool cities (De Landa 1997), and not a hybridity of difficult modernist juxtapositions emanating from the metropolitan attractors operating elsewhere. ${ }^{4}$ Our slowness would occur at the magnetic core, as the slowness of the attractor, and not as a premeditated halt of human movements, not as a manipulation of the split lives vacillating around the new borders. The South was attractive and permissive, one could say, not "tolerant." Due to that often overlooked difference in between what was, and what is now supposed to be that openness and "porous" existence of ours, it is only reasonable for the Southern popular sentiment to remain forever suspicious of the newer forms of the broad imagined and invented articulations of horizontal belonging, forms questioning the old communality, differently hybrid. Those forms (such as national or supernational), even if accepted and performed, are usually perceived as coming from elsewhere.

The old Southerner knows what the new bordering hides: a border is always also preserving the sovereignty of a system, since central powers dissipate their forces in order to maintain the systemic edges, to prevent turbulence stemming from the imminent and inevitable encounters. Therefore, a border as the celebrated hybridity (either in life or in methodology) remains haunted by the spectral manifestations of what a Southerner readily despises - the bureaucratic reasons of the State that from the Norman Sicily to the European Montenegro always brings the (un)wanted second emanation of the Northern/Western "order." The new hybridity is not only superficially celebrated, but also, and that is a novum, calibrated.

With that historical shift in mind, with "protestant" forms of rationality marching south, it is intellectually legitimate to ponder over the Said-esque moment when the Northern desire of the South as the place of warmth (where lemons are blooming, wo die Zitronen blühn) turns into a methodological and organizational 
Drang nacht Süd, while the impoverished working force migrates towards the West). What was once the multiplicity and malleability of life-forms, becomes, therefore, a multicultural stasis; the open-minded warmth of the lived vis-à-vis turns now into a carefully and painstakingly crafted "multicultural competence" operating, primarily, as a systemic provision.

The problematic metaphors and realities of "New Europe" (mostly meant as a post-communist one), juxtaposed against the Europe sensu stricto, operate politically and geostrategically for almost three decades already, and normally also contain large territories of the South. Moreover, with re-articulations of the core, related to the recent discursive management of the crisis within the EURO zone, the South reemerged as a "lazy" counterpart to the northern (Weberian) "spirit of capitalism." A history of the EU enlargement and a history of the recent financial meltdown (followed by the austerity fascism imposed to the citizens in the South) played along those same or at least similar boundaries as the previously discussed forms of belonging and of the "multicultural" juxtaposition opposed to the old hybridity.

It is not surprising to see the South effectively removed from the vocabulary of the European Union for the countries oddly pushed to the core, and officially reserved for the otherness that still stands beyond it: the South still plays prominently in the discursive articulations of "South-Eastern" (i.e. standing for the alterity of Balkans) and of "South-Mediterranean" (i.e. standing for the alterity of the Arabic/Muslim). The united Europe rhetorically lost the traditional South only to constantly reinvent it in various moves of internal political divisions and economic pressures. The loss of the South as a concept is not, therefore, stemming from recognizing the complexity and heterogeneity of Southern Europe, but is the expression of the very ambivalent ideological stance, the one that used to effectively divide my Croatianness (from Rijeka/Fiume) from my Italianness (from Fiume/Rijeka), and is now moving the lines of tension more to the south.

The inherent problem of the academic cartographies in the South, either concerning cultural studies or any other imported intellectual articulation, is not in the physical or even the political dimension, but is mostly in the specific temporal dimension, a temporal disjunction in what appears like a unified "European" structure of feeling. A European South is kept in the state of "not yet, still not there" for all intents and purposes, and the cultural studies practitioners are in no way exempted.

In the light of all those problems it is safe to say that the South now is hardly the new promised land of the celebrated global "flows," of the hybridity-inmotion (such as in multicultural melting pots and/or salad bowls of the postindustrial metropolis), and therefore is not the promised land for the spread of the metropolitan cultural studies as their gepflegt academic self-reflection. Still, cultural studies (mostly in politically relatively deflated forms) seem to resist such an inhospitable climate, stemming from the most unexpected places, from the State 
institute of national language and literature in the Republic of Macedonia to traditional English departments of Spain.

\section{Capitalist Citizenship and Southern Cultural Studies}

In the European South, a large region encompassing all the ethical paradoxes of difficult modernity, engaging with cultural studies must still entail the ongoing quest for alliances, a search for those modes and articulations of life that congenially share and inform our political phantasies, and, in the constant autopoietic loop, allow those productive phantasies to stem in the first place. That quest is, then, undeniably related to those realms of the relational social that could find themselves more productively and more progressively articulated, spurred by the intellectual project of cultural studies. In spite of many defeats so far, I claim that these quests must still extend way beyond the world of intramural education and not just in regards to the range of topics analyzed. Cultural studies must engage with real politics, albeit subtly and in the broader sense, preferably beyond any partisanship, and contribute, in the so-called real world, to the desirable defetishizing of the notion of European (neoliberal) citizenship, to help freeing the subject (agent) of cultural studies (as a practitioner and as an interlocutor and ally) from the various "not yet" and "to a point."

The added intensity of "the political" that cultural studies promise must therefore come from the interstitial movement, from a dynamic threshold dividing/uniting/dividing/uniting (etc.) systems (for example those formed in between academia and the "street"), and I continue to consider cultural studies to be such an interstitial articulation, not as much in between disciplines and departments as in between the politically vested tension fields of the relational social. Jokingly combining derridaean and deleuzean vocabularies one asks oneself: If something is about to fold, turning from the flow in some contingent and temporary fixity, would that something decide (!) to fold differently if we are to have our say?

To make things more clear, it is not about being inspired and/or recruited by this or that theoretical and political label. As Lawrence Grossberg points out, cultural studies are inherently political simply because it is articulated around the necessity of tackling the power relations and because it wants to change the world:

In fact, one cannot choose not to change the world, for that choice is actually a choice to leave unexamined and unchallenged the existing relations of powercertainly a political choice. The only choices are how self-consciously one approaches this work, and to what end. So, somewhat inevitably, cultural studies does see itself as intervening into the real world of political struggle, but its intervention is defined by its effort to produce knowledge that may help change the world. (Grossberg 2010: 97)

Still, all this doesn't come without a warning: 
There has to be a difference between scholarship (telling a better story)-analyzing particular formations and mechanisms of power and subjecting them to the challenge of contingency and possibility-and the statement of political values and enactment of political action, where the latter refers, rather naively for the moment, to collective action aiming to transform the institutions and operations of power and the political. (Grossberg 2010: 97)

The example of the paradoxical Southern citizen, seen as the subject resisting his/her "citizenship" (both a partner in our intervention, and the elusive object of our analysis), should prove that this Grossberg's point of distinction should first be accepted, especially in terms of a much needed defense of academic humanities and social studies from the flattening of those complex relations into some kind of an unhappy and intellectually deflated continuum of the capitalist "postpublic sphere." Upon the initial acceptance, that distinction must be complemented with addressing that very element that Grossberg finds inherently problematic: the naive versions of collective action. The main problem, therefore, might not be in the superficial political rhetoric that occasionally blurs the intellectual achievements of cultural studies, even if that problem remains visible and is not to be neglected. In fact, the more pressing problem to tackle is the very nature of the political, not in its label/school/orientation or in its spacio-temporal location.

If our politicality is the politicality of "better knowledge production," it is certainly true that it is impossible to envision any useful knowledge production happening in vitro, or as some self-denying relation of unrelatedness. Therefore, while cultural studies practitioners need to maintain the distinction of analytical politicality vs. other forms, and remove the "anything goes" label (all-too-easily attached to our efforts), we must be careful to take into consideration also a necessity of our discovering of those other forms, and of our learning from them but also, and that is crucial, with them. My modest but ongoing advocation of the theoretically-informed and performative ethnographic work is exactly about the continued envisioning of uneasy and new politicalities, such as ones that are personal, individual, situational, interstitial, eventual, dialogical, protean, queer, transgressive, piratic, able to fill a gap in between academic politicality and the heterogeneous politicalities of the street/network/community, the gap that appears to be the unwanted consequence of our need to maintain the necessary distinctions described by Grossberg.

The simple fact that there cannot be the "right story" out there for the poststructuralist narrator, just a "better one," might also imply that we didn't think low enough or high enough: warm in winter better than cold, alive better than dead, freedom better than oppression, all that better if for all, and not just for some. In the first world troubles (including such an all-embracing one like a mode of production itself) no right story is possible, since they are all humanly and humanistically impossible. Decidability is a shameful intellectual betrayal, but only in theory: it still needs to be promoted, if and when it is situationally necessary. 
All these dilemmas are directly invoking another crucial distinction Grossberg proposes. Talking about the notion of everyday life and taking a stance in regards to some of the older conceptualizations (such as Lefebvre's) Grossberg writes about everyday life as the other side in the binary distinction between the institutional space vs. the space of everyday life. For Grossberg, everyday life is uncatalogued, habitual, often routinized, unpredictable and banal (Grossberg: 2010: 278), an unredeemable excess or residue (beyond the structural and organizational), that cannot be described with certainty:

\begin{abstract}
And despite the fact that it functions as the common ground of all human thoughts and activities, it has as well a certain mysteriousness, since it always remains outside of science and social theory. In fact, it is opposed to abstract thought, which is incapable of ever understanding the dense particularity of daily life. (Grossberg 2010: 278)
\end{abstract}

These two crucial binary divisions/distinctions (first one regarding different realms of the political and the second one regarding the institutions vs. the everyday life) seem to invoke two mutually familiar but different takes on European citizenship, both of which relevant for our understanding of who we are addressing in the South, who is the subject of our anti-disciplinary politics and the possible pirate we need to stimulate (Pužar 2010).

In Balibar's account, the peripheral zone, a zone of conflict of cultures and of differences in economic prosperity, is exactly where "demos" is formed, people ready to stand united under banners and rituals of $\pi$ o $\lambda \imath \tau \varepsilon i ́ \alpha /$ politeía, in-vested as citizens proper (Balibar 2004b). The marginal, therefore, stands at the very core; the border is not only infested by the spectral manifestations of the Kingdom (or better: $\Delta \varepsilon \sigma \pi \mathrm{o} \tau \varepsilon i ́ \alpha$, Despoteía, the rule of the lord(s) over slaves, based on tradition beyond the legality of the arrangement), but also seems to fold right back to the heart of the imagined/intended "becoming democracy."

While generally quite hopeful, Balibar is careful in his analysis of the evermoving dynamism of inclusion and exclusion, reminding us of the stigmatization and repression, going as far as to juxtapose the notion of "Europe as a democratic laboratory" to that of the "European apartheid" (Balibar 2004b: x). A democratic citizen, for Balibar, is formed as the uneasy vacillation between a "sovereign subject" (a subject member to the sovereign) and a "self-owning individual" (owning the faculty to develop his/her own capacities in the "commerce" with others) (Balibar 2004b: 198).

I would like to discuss the subject of cultural studies (both a practitioner and his/her interlocutor(s)) exactly in the light of this inherently paradoxical articulation of citizenship, of its equalities, its freedoms and its responsibilities, and more so if those articulations constantly collapse into subalternity, oppression, and corruption, revealing the imaginary nature of the concept, or its fetish-like dimension. For the Southern resisting/chaotic/insurrectional subject, trapped in his/her own problematic and frustrating temporality of "not yet," all these paradoxes are 
strongly felt and more alive than ever. (S)he is "promoted" to the guardianship of the outer borders, including those of cultural studies, while remaining the one that knocks at the doors of the core-Europe.

Sandro Mezzadra adds to this, in his roughly Althusserian move, the epistemic dimension that extends the specific dualism of the citizenship into a sort-ofgnoseological dualism. He describes the complication of being a European citizen by reintroducing the old motif of externality, a constitutive outside, so dear to post-structuralist theory:

\begin{abstract}
If you take a concept such as the modern European notion of citizenship in its claim to be valid beyond and against all "particular" belongings and loyalties, you can easily see that (...) a specific form of interpellation is constitutive of it - and that the modern concept of citizenship (let me add: as all modern political concepts) has a constitutive outside, the heterogeneity of the "forms of life," of the "habitations of the world," that define its addressees. This is what I have in mind when I talk about the strategic role of "encounters" and "heterogeneity" in the fabric of modernity. (Mezzadra 2011: 158)
\end{abstract}

In Grossberg's initial definition of everyday life as the (roughly) uncatalogued excess of life opposed to the institutional space, in some of the Balibar's depictions of pre-democratic insurrectional modes, and those uneasy ones as the modes of exteriority, of the popular sovereignty and such, and certainly in Mezzadra's notion of life-forms standing as the "constitutive outside," one could detect a peculiar epistemic positionality: in spite of the full acknowledgment of dynamism and vacillating of and around the borders, and in spite of the fairly sophisticated vocabularies, the precedence seem to be tacitly given to the structural dimension of life, with various anti-structural forms considered either external to the life of politeía, or at least largely elusive. There is a traditional modernist impetus to rationalize here, that might require a proper response from the researchers inclined more towards vitalist and radically empiricist inspirations, not to mention from humble deconstructionists, or from those engaged with performative qualitative methodologies.

It is also possible to think of the occasional dualistic epistemic positionality of cultural studies as asking for different interventions, such as those regarding the chaotic nature of the structural, the inherently erratic nature of the institutional realm. I am thinking of interventions such as the one of Chantal Mouffe's "agonistic pluralism":

\begin{abstract}
No doubt, by stating that democracy cannot be reduced to a question of procedures to mediate among conflicting interests, deliberative democrats defend a conception of democracy that presents a richer conception of politics. But, albeit in a different way than the view they criticize, their vision is also a rationalist one which leaves aside the crucial role played by 'passions' and collective forms of identifications in the field of politics. (...) (Mouffe 2000: 0)
\end{abstract}

It is not that cultural studies haven't been working with theories of the antistructural and with the elusive emotionality and passions of social life for some time now, Grossberg himself being a careful observer and an important contribu- 
tor to the "affective turn," but the cripto-structuralist post-structuralism posed some definite methodological limits to such a work for a long time, in many cultural studies departments, and around the globe. Of course, a response to such a problem cannot exactly be (only) in the counter-moves towards an old-fashioned materialism. The sheer fact of various post-structuralist conceptualizations of small freedoms (such as Foucault's stylizations and heterotopias or De Certeau's tactical moves of resistance) being both insufficient (for the creatures tragically "not yet there") and conceptually tired, doesn't really mean we can simply reinstall hope in the large historical blocks of the early modernism "behaving" in a Hegelian progression. Much less so could we trust the promises of the early postmodernist constructivism, and its fragmentophilia and iconophilia, not to mention a techno-utopian optimism.

The ontological and not only chronological primacy of complexity and chaos over the secondary crystallizations of historical and institutional contingencies, the much needed questioning of the pretended rationality of taxonomies, all that needs to be reflected in the new positionality of cultural studies, but not as a diluting of the ethical stance and political agency into some boring postmodern relativism. On the contrary, the full acknowledgment of the primary chaos that constantly and daily anti-catalogues our contingent catalogues might be more productive for the anti-discipline seeking at least some specific demarcations towards various "orderly" disciplines based on the traditional quantifications and taxonomies.

Luckily for the outcome of all this, all three authors whose writings inspired this chapter, the cultural studies classic, the political philosopher and the flexible sociologist, offer enough exits through notions such as multiple, the anti-strategic, the transnational, the heterogeneous, the affective etc. addressing the uneasy dissipation at the edge of the rational scholarly ideation, of borders towards the outside, and all three, in different ways, maintain the promise of progress and social justice.

Yet, when I think of cultural studies in the South, I feel they are more than the sum of their paradoxes, and the Derridaean cadrage of moving borders. There is an excess, yes, but neither inside nor outside, neither (only) within the institutional realm, nor (only) in some blurry street-wise banality of the everyday. Every honest practitioner I know of is a creature of the border, in the border, dwelling not just in the overlap, or in the vacillation in between externality and internality, but in the fullness of what only appears to be interstitial, in the "natural" simultaneity and eternity of complex forms. Chunks of the chaos are conveniently named (folded, sedimented), yes, but never abandoned, and most people I talk with don't have properly dialectical lives. As important as it is to put two or more types of orders together, in the analytical and political framework, and to confront them in order to assure a proper ground for our analytical work, it might be equally important to deal with the complexity of "outstanding" forms, but also with the inherent complexity of what is mainstreamed, institutional and systemic. 


\section{Eliteless Transitions and the Post-Marxist Structure of Feeling}

In my occasional ethnography of roots, of my own previous academic belonging, I am collecting the voices of the Southern (and South-Eastern) cultural studies students and practitioners, the main link versus "other knowledges" and "other politicalities." Each voice collected testifies for the complexity of "becoming citizens" and the troubles of becoming subjects and agents of cultural studies, seen here as a force of stimulation, a production of added intensities.

Some of it is a typical student rant over the higher education that fails to deliver the higher promises, that also, in the case of the "progressive cross-disciplinary humanities," entail a visible political disillusion:

I am thinking how much more brave we were as freshmen. The university is maybe teaching us to see things differently, it emancipates us...but not much...I remember how self-aware and confident I was before the system "put me in place." I am not beaten down or anything...just not so brave, and not mesmerized. And we were supposed to flourish, to learn, to enjoy. I did, at first, but after that...shit...shock...I cannot even talk about others, but the situation is the same or even worse. We doubt our future...disappointed. Blocked. I want to leave, to go somewhere where things function at least a bit, and where I'll have at least three mental orgasms per day. That's it. (...) (Tina, 26, /real name withheld/, personal communication, 2012)

I am not saying that the same tone could not be heard from a student of any other major forced to study within the underfunded and under-resourced departments of the South (including the South-East), but I claim that the initial hope entails a different political dimension and a distinct tone for the intellectual project of cultural studies.

A graduate student and the young independent scholar responded to my private lamentation about the situation on the ground, in somewhat more analytic terms:

I don't really know anything about today's global positioning of cultural studies, but I see what's happening in Croatia. That concerns me, actually. First they started to imitate, but even that failed because not many wanted to tackle the wide list of "criteria" of how cultural studies research should look like. Others flirted with performance studies and have produced the nastiest drag-queen of critique, third where inclined towards plenums [a recently popularized form of direct democracy in some Southern universities, A.P.], subversive film festivals, and similar "political" events and were picking up on the cheapish ideological catchphrases. I can't see that any among us who are in this or that way connected with "academic field" [of cultural studies, A.P.] is really dedicated to the in-depth analysis of what cultural studies really is, nor we try to implement any of the research designs. (Benny, 25, /real name withheld/, personal communication, 2012)

Between the lost purpose and failed methodologies, what concerns me most is the familiar picture: a widespread existence of cultural studies' political gestures and the "brand," unsupported by proper analytical work, and, on the other hand, the superficial acceptance of the models of cultural analysis, sadly devoid of the crucial political dimension.

Presenting, for the Italian public, a new translation of a book by Paul Bowman, a mainstream representative of the new(er) British cultural studies (Bowman 
2011), an editorial statement introduces the readers to cultural studies as a "new line of research" which explores essentially "political" (using also the quotation marks) issues, such as the relation between culture and power, between culture and change, and also the relations between high and low culture, revealing the deeply-rooted prejudices either in the institutions of the real world, such as the media, the family or the State, or those pertaining to the world of academia. The editorial intention is clear, yet implicitly pessimistic:

\begin{abstract}
The intention is to spur in Italy a development of this line of research, which counts among its real precursors both Antonio Gramsci and Ernesto De Martino. In our country, the literary studies, English studies and sociosemiotics, did in part explore the legacy of the British cultural studies, although its ethico-political vocation and the charge of the intellectual militancy were mostly betrayed and debased for various reasons. ${ }^{5}$
\end{abstract}

In thinking about those "various reasons," I want to briefly discuss only two that I consider fundamental. These two dimensions of the sociopolitical and intellectual life in the European South (and South-East), along with the broader logic of the capital and the fragile articulations of citizenship, continue to influence a destiny of regional versions of cultural studies. I am talking here about the partially imaginary process of "transition" from a "totalitarianism" towards a "democracy" (in Croatia, Italy, Spain and Portugal, and in a way also Greece and Turkey), and, in close connection to that process, about a position of Marxist thought in Southern academia and intellectual public. A latter dimension, the position of Marxism, seems particularly important in the countries of ex-Yugoslavia (Slovenia, Croatia, Bosnia and Herzegovina, Montenegro, Serbia, Macedonia and Kosovo), and in Italy.

A notion of transition, as promoted by those trying to describe a historic shift between the State ideologies and the State-promoted modes of production, doesn't really work very well for the researcher that understands the articulations of the relational social as fundamentally pervaded by an ongoing and eternal transitoriness. It takes quite an undertaking in modernist rationalism and traditional historiography to even begin to trust the roughness of the "transitional" taxonomies as the intellectually viable way to describe the complexities of life, especially at the level of the individual experience. Still, the changes that enveloped most of the countries in the South and South-East at the end of the twentieth century (either similar or different from the changes that happened in the East and in the North,) supported a very specific type of temporality. I explained before that in my opinion the main trait of the Southern temporality is always a sort of "not yet there." Yet, there was obviously a much earlier historical moment of moving centers towards the North and the West that probably organized that discursive game of "eternal catching up" on one's own ideal-type citizenship that emanates from elsewhere. 
Nonetheless, within a specific framework of recent European views on the post-communist "New Europe," there seems to be only one transition worthy of interest: the one from the post-Stalinist socialism dreaming of communism sprinkled with capitalism (in Yugoslavia) and the post-Stalinism dreaming of communism (in the East and South-East) to the neoliberal capitalism acting-out its type of democracy. Of course, there is a never-ending transitional narrative of Turkish (non)-secularism, used for the homogenization of the "core-Europe," plus two "happy transitions" from fascism (in the Spain and Portugal), featuring democratic savior monarchs or such, neglecting and suppressing important aspects of the historic trauma. The most interesting might be the Italian case of transitioning from the Marxist-Catholic "democracy" into a post-Marxist-post-Catholic "democracy."

When Hungarian-Irish scholar Arpad Szakolczai wrote at the beginning of our millennium about the "East-European condition" he argued that the communist regimes not only were established under conditions of heightened liminality, but could only function in the liminal regime. Communism, according to Szakolcai, was a unique political system that kept the entire society stuck in a permanent state of confusion, uncertainty and transitoriness. Communism in his account crushed the existing social elites and succeeded to maintain the inherently eliteless state by introducing a "counter-selection" and preventing the formation of elites.

\begin{abstract}
I argue that the countries of the region are caught in a maelstrom from which they are not able to get out on their own. This is because the events of the century further and further magnified their precarious, liminal condition into which they became permanently stuck; and because, as its single most important legacy, the communist experiment fatally damaged the only segment of society that could have provided leadership out of this maelstrom, its elite. (...) The main tasks are to end this permanent state of transitoriness of the region and to build elites. This makes the joining of the European Union an imperative, and also calls for specific, concentrated efforts and political will, again on the part of all sides, but especially from the part of the EU, to engage in major long-term programmes of elite-building." (Szakolczai 2001: 1)
\end{abstract}

There are many obvious flaws and imprecisions in Szakolcai's argument, but his vision introduces several interesting points for future critical analysts. Firstly, one needs to acknowledge the structural similarities in transitions from right-wing dictatorial regimes, such as Spanish or Portuguese. Secondly, a distribution of "democracy" is more complex, especially among the lower strata. To give an example, the shift from the late-Yugoslavian self-managing proletariat towards the raw precariat of the neo-liberal era is certainly a shift between two types of democratic deficit, two types of "becoming democracy," and not exactly between a totalitarianism and a democracy. Democratic impact on what we call human life, so central to the efforts of cultural studies, remains in a fragile relation with the State-propelled or EU-propelled fictions of democracy, human rights and civil participation, and that relation is never devoid of paradoxes, problems and gray zones; its reach within a population is hardly sufficient in the best of cases. Third, 
the communist regimes produced new elites, an entirely new ruling class, famously described by Milovan Đilas (Đilas 1957) a class that entered into various strategic alliances with the remaining fractions of the old bourgeois elites. Fourth, they maintained forms of cultural state and its rituals, as conceptualized by Marc Fumaroli (Fumaroli 1991), including the academic forms of intellectual elitism, and all that regardless of the broader access to higher education, and in spite of the widely-spread ideological oversight.

Still, one thing is certain: any crumbling set of social relations produces the appearance of sways between always coexisting structuration and chaos, a "tangible fiction" of historical shifts within the simultaneity of stasis and movement. One neither needs to go back to Thomas Khun to understand that a necessarily liminal state precedes a new contingent dominant articulation, the one that gets normalized, for the time being, into a "paradigm," nor to re-visit the Foucauldian motifs operating within cultural studies. Liminality could be seen here, in strictly Turnerian terms, not as a whirlpool, but as a naked temporality of the postponed. Such a temporal modus of suspension never operates without the set of orientational metaphors and ideologemes. One wonders if the Southern dismissal of the institutional order and putting trust in various local sheriffs and tribal/national leaders could be compared with the lack of viable research designs in critical cultural analysis, usually coexisting with the fetishistic adoration of individual theoretical "leaders."

It is not that communism (or whatever existed under that aegis) didn't dispose of the traditional elites, in some cases as late as in the post-1968 reactionary backlash of various petrified regimes in the European East and South-East, but the more pressing question is of the neo-liberal capitalist subversion of the public sphere that happened at the very core of this imagined transitional "path to democracy." It was not communism that restructured the Humboldtian universities in the South, but the recent "Bologna reform," bringing stronger connections with a world of globalized capital and a certain suspect Americanization of European higher education. Sadly, these external pressures came only after the internal methodological and ethical implosion of the progressive humanities from the mid1980-ies. No wonder, then, that Renate Holub in her famous chapter on Italian post-war intellectual life writes about the "exodus from the public to the private sphere, and its concomitant abdication of moral leadership on the part of the intellectuals, as symbolised by the crisis of reason." Holub describes a shift "from a position of cultural critique to that of cultural studies," equaled with "losing a good deal of its critical edge." (Holub 2001: 11-12)

Only when the ritualistic cultural state started to fall prey to the forces of Spectacle, and the welfare state to the world of precarious labor and forced austerity, in that very moment of the imaginary "democratic hopes," cultural studies entered the Southern universities and started to flourish in places such as Italian Catholic universities or Croatian nationalist public universities. But while the bourgeois 
public sphere remained a respected if increasingly obsolete ex-enemy, a kind of spectral cloud, and while the anti-structural movement "occupies" the public zones in new gestures of anarchic insurrectionism, cultural studies still fight the old battles invented as a soft-leftist refreshment for traditional British academia, and not as a viable way to preserve the critical edge of Southern Marxist cultural critique. Because, and that opens a next step in my argument, exactly the weakening of the Marxist influences allowed cultural studies to gain institutional footholds and the general prominence in the South.

In the words of a Croatian graduate student:

\begin{abstract}
And then this hip idea gets imported to spaces that show an intellectual ambivalence towards their own Marxist background, and the whole thing turns posh. If we would be mean, we could say that somebody finally listened to Rorty and directed cultural studies towards the benefits of clientelism. (Benny, 25, /real name withheld/, personal communication, 2012)
\end{abstract}

Both a Boratization (a difficult and twisted othering) and a destiny of cultural studies in "other Europes" depend, in several aspects, on the position of Marxist or quasi-Marxist philosophy and dogma. In 1963 Fernand Braudel wrote:

Whether or not Marxist philosophy is that of the rising working classes and of Socialist society, or industrial society, it has clearly played a dominant role in the West and in the world, which it divided as, until only very recently, it divided Europe." (Braudel 1995: 404)

The fragile and ambivalent relations between cultural studies and Marxism are often discussed and debated in cultural studies (for example: Harris 1992; Hutnyk 2004; Bowman 2007) but the challenge in the South is to recognize a specificity that is both quantitative and structural. I am thinking here primarily of Croatia (and other similar South-Eastern countries) and of Italy, for decades probably the most Marxist country of capitalist Europe. Both in the South-East and in Italy (possibly in a way also in France and some other limited political and academic circles elsewhere in Europe), Marxism gained a huge influence at the end of the Second World War and fueled the renewal of the critical public sphere, socially sensitive media, huge parts of new humanities, and also helped the liberal, DemoChristian, and other centrist governments to "balance the books," in moral sense, of the European welfare state. With the real-life help of the syndicalist forces, it rose to enough power to dictate various intellectual processes, and then, after 1968, started to "inform" various forms of Post-ism that brought the internal divisions and branching.

When the events of the mid-eighties lifted the proverbial iron curtain that separated "the core" from the huge realms of what is now a "New Europe," the leftist scene in Italy and elsewhere was already disorientated enough to start to reinstall forms of diluted Marxism taken from the countries of the liberal-democratic tradition, countries in love with institutions, and to "democratically" allow various unpleasant right-wing revisionisms and nationalistic rituals. Cultural studies, then, 
without its inherent "guilt" finished not being localized as some sort of Bhabha's "Third space" of semantic negotiation and counter-hegemonic subversion, but in fact turned for the Southern leftist academia into its own indirect post-socialist "Third way."

So, when cultural studies flourish "after Marxism," that doesn't mean they are openly against Marxism, and that also almost never implies that cultural studies in the South take a "differently revolutionary" stance, let's say anarchist, inspired by the contemporary social movements. Inspired by various combinations of the French post-Marxist (and therefore partially Marxist) theories with the syncretistic legacy of Birmingham, Stuart Hall and the moment of the British "even newer" left, these studies still sell the dilution of Gramsci in places that once knew of Lenin.

Using a tongue-in-cheek analogy with Vattimo's "pensiero debole" (weak thought), a regional version of sort-of-deconstruction, we could say that cultural studies promote a "better capitalism" and a "cleaner spectacle" under the aegis of "marxismo debole."

\begin{abstract}
In Italy, cultural studies has often been associated with those media studies departments examining "audience studies". These departments have tended to be situated within Catholic institutions or universities influenced by church teachings. (...) Cultural studies in Italy has been shaped by its British counterpart, allowing Italian academics, predominantly within Catholic institutions, to reintroduce ideas associated with the key Italian Communist theorist of the 20th Century. (De Blasio \& Sorice 2007: 2)
\end{abstract}

Of course, such a reintroduction, if properly historicized, must be read as a regrettable reduction. The reason for such a harsh diagnosis is simple: if anything, at least in terms of the revolutionary and insurrectionist impetus, Southern subjectivity and citizenship didn't need to live in the suspension of "not yet." The South has showed in the past various forms of piratery, brigandism, carbonarism and subversion of the institutional frameworks, a range of leftist guerillas and of workers' movements, and a notable presence of critical academia, and there is no acceptable reason to avoiding building upon such a rich tradition of the anarchic flux, co-existing with "Catholic" rituals.

\title{
Conclusion: For the New Direction
}

In this essay, I was trying to describe what the European South as a spatiotemporal and ideological articulation could be in the first place, and how it is working tacitly, as a set of specific relations that co-organize Europe and its cultural studies. The most important lesson coming from this analysis, inevitably partial (both as a bias and as an incompleteness), is the expected one: my pondering over the broader conditions of emergence for cultural studies in the European South shows that a destiny of the anti-discipline might not be inherently different 
from both a destiny of Southern capitalism and of the Southern "democracy." Even more so, those destinies seem to form a strong analogy or even a structural homology. But, if those processes are structurally similar or akin, is it because any cultural studies methodological, ideological and institutional localization so far, anywhere in the world, assumed a natural link between the capitalist mode of production in its post-fordist version and capitalism's own academic brand of the post-Marxist critique? Or, is it that in this particular spatio-temporal localization of the intellectual project called cultural studies one needs to test the possibility that the import of cultural studies to the South is nothing but a form of latecapitalist colonizing of the Southern humanities and social studies, supporting a shift from the models dedicated to the participation in the forms and rituals of (cultural) State (including the falsely post-national communist one), towards the various neo-liberal mode(l)s of knowledge-production?

The old and tired Southern university, which once entailed the knowledge of the western world, is now exposed to the neoliberal attack under the aegis of "Bologna reform" that started as a self-professed tool of liberation only to finish in the oppressive bureaucratic schemata of the imposed "accountability" and "competitiveness." It is clear that the cultural studies in the South benefited from that wave, and therefore stay in an uneasy proximity to the dangerous dissolution of the important (academic) politicality of better knowledge production described by Grossberg. Additionally, the institutional forms and rhythms of cultural studies are still akin to the odd transplant, a colonial effort, methodologically maladjusted for the insurrectional and liberatory articulations on the ground, at least if the useful politicality is "at stake." Of course, the other transnational examples of slow localizations, such as East-Asian and South-East Asian cultural studies, encourage some optimism in regards to the flexibility of the project and the adjustability of its inherent politicality.

Certainly, in concrete terms, there are visible differences within the South itself, in between the old and new capitalists, in between those Southern countries emancipating from the right-wing and those emerging from the left-wing forms of totalitarianism (and dealing with the revisionist agenda related to the totalitarian history). The South is Catholic and Orthodox, Muslim and Jewish, and heterogeneous in terms of different branches of the Indo-European linguistic families (and occasionally linguistically living beyond them), and includes the obvious divisions in the modern imagined communities and networks of belonging. The South is, therefore, divided and complicated, and its self-understanding Southerness can only be envisioned as the elusive shadow of the equally complicated North.

Yet, in spite of those many colors and the internal heterogeneity of local cultural formations, the destiny of the intellectual project of cultural studies in the South seems to be similar regardless of country (with the possible exception of Turkey). It is the history of slowness, of obstacles and failed ethical promises. That is not to say that such a destiny might be inherently different from how cul- 
tural studies play(ed) in some other academic constellations, but it is to say that the academic articulations of the anti-discipline didn't achieve much in terms of tapping the rich vein of the Southern potentiality for the subversive.

When I concretely helped the processes of establishing the anti-discipline at an undergraduate and graduate level in Croatia, in what is now my personal distant academic past, I inadvertently helped their fragmentation, filled with jargon, guided by the tricky "Bologna" style of the new humanities. Some autonomy within the system was envisioned but soon dissolved into "rules." Ethnography was not excluded, but it never gained importance, and most of the courses were either heavily theoretical or simply utilitarian. Elements of progressive thought traditional to the area were never systematically studied, and the link with the new social movements remained rhetorically important, but mostly private, random and increasingly sporadic. If some pragmatism was there, it was clearly of the capitalist and market-oriented, and not of the revolutionary kind. The employability of graduates, within the existing crumbling markets, was our first consideration. In the meantime, those programs intellectually deflated into a gray normalcy, operating at the general level of the local academia and no "piracy" is visible. Still, some of the best and the loudest voices of the regional student movement, of the "occupy" movement, movement of the direct democracy etc. came from those academic environments, and that fact was never accidental.

The paradoxical nature of those processes and events entails both the failed promises and the ongoing hope for the organic work of the intermediary "agents" using academia in the heavy task of social change. After all, there is a happy chance of positive radicalization of social life in the South. In order to use that chance as a real academic opportunity one needs the radicalization of the methodological apparatus. For me, that remains a theoretically informed performative ethnographic encounter, emulating the fluctuations in/of the field and resonating with our specific politicality, but also the old idea of bold, theoretically informed descriptions, publicly posed as interventions. A strong utopian element of those methodologies is the anti-structural constitutive of any academic endeavor in the humanities and of the dynamic public sphere, and our real critical vocation, and it is not to be disposed of as "intangible" and obsolete for the sake of any rational "reconciliation." Its ethical and developmental role in antagonistic democracy remains crucial.

The Southern cultural studies need to allow the spirit of disorderliness to contribute to the general effort of "staying clean," either methodologically or politically. The action plan for the progressive cross-disciplinary humanities can be, in my opinion, still rationally formed around two main issues which are both ethical and political, but with very direct implications to the anti-disciplinary destiny of cultural studies: around the subversion of commodity production and around the self-management and radicalized quest for autonomy. (Pužar 2007) One doesn't need to burn any roofs, though: as with any existing middleclass radicalism, most 
interestingly described by Stephen Cotgrove and Andrew Duff, cultural studies can simply engage with small-scale instead of the large-scale agendas, with the communal and fluctuating instead of the associational and ordered, with public interest instead of market forces, and with self-actualization instead of the economic growth. (Cotgrove \& Duff 1980) In terms of the methodologies (described formally, but enacted in many different concrete forms), such a middle-class radicalism, as ironic and self-ironic as it might be, necessarily implies a much needed increase in the "action research" type of qualitative projects, the proper training in critical ethnography and auto-ethnography for every single cultural studies student or practitioner (even one inclined to study gender politics in the Shakespearean problem plays or such).

A theoretically informed turn towards "life," towards a directness of encounters, implies a more traditional reading of Gramsci (and even Williams) in the matters of the role of "organic" intelligentsia, the exercise in old and new materialism that corrects the cripto-structuralist inclinations visible in how cultural studies sometimes misused the valuable philosophical legacy of the constructivist post-Marxism only to produce something that can be called a politically irrelevant disciplinary politics, missing on the "better knowledge production," especially when and where that better knowledge must meet its extramural life. Cultural studies in the European South must, not without some "historical urgency," find a methodologically and theoretically better way to dispose of Boratization, either the external or the interiorized one. In fact, only the methodological maturation and the political relevance of the Southern cultural studies can replace the models based in the suffocation by the anti-utopian and orderly "not yet" of the "New Europe."

In the words of a graduate student: "In spite of everything, I see our Balkans, South America is interesting too, as a space capable of offering a new direction, maybe exactly due to the ambivalent view of the past, or thanks to the boldness of us, the young ones..." (Benny, 25, /real name withheld/, personal communication, 2012)

The Boratization, in its role of organizing and coding the borders of European cultural studies, must be replaced with that new direction, promising new forms of critical and creative localizations, working with and within social movements coming from the South(s), in America, in Asia and, finally, in the very cradle of old arrogance.

Aljoša Pužar is a Croatian (and Croatian-Italian) cultural studies scholar, writer, and social critic working in South Korea as a professor of cultural geography and gender studies at the Graduate School of International and Area Studies (Hankuk University of Foreign Studies, Seoul), and as an adjuncy professor of cultural studies at Underwood International College (Yonsei University, Soeul). He co- 
initiated and co-funded the first full BA and MA program in cultural studies in Croatia and was a founding member and the first chairperson of the Croatian Society for Cultural Studies. E-mail: aljosa.puzar@gmail.com.

\section{Notes}

Current Issues in European Cultural Studies, ACSIS conference 2011.

A mockumentary "Borat: Cultural Learnings of America for Make Benefit Glorious Nation of Kazakhstan", directed by Larry Charles, written and produced by Sacha Baron Cohen, was released for 20th Century Fox in 2006.

3 The classical example remains: Slataper, Scipio (1912) Il mio Carso, Firenze: Libreria della Voce.

$4 \quad$ Braudel's classical studies showed when and how that central "elsewhere", i.e. the geographical shift of the economic and cultural powers, came to be: "Freed from the spell of the Mediterranean, the active life of the seventeenth century developed in the vast reaches of the Atlantic Ocean." (Braudel 1977: 25)

5 http://www.progedit.com/libro-301.html

\section{References}

Andrijasevic, Rutvica (2005): "Lampedusa in Focus: Migrants Caught Between the Libyan Desert and the Deep Sea, Feminist Review, 82, 2006, 120-125.

Balibar, Étienne (2004): “At The Borders Of Europe”, http://makeworlds.org/node/80 (accessed 19 April 19 2013)

----- (2004a): "Europe as Borderland", The Alexander von Humboldt Lecture in Human Geography, University of Nijmegen, November 10, 2004, http://socgeo.ruhosting.nl/colloquium/Europe\%20as\%20Borderland.pdf (accessed 19 April 19 2013).

-- (2004b), We, the People of Europe? Reflections on Transnational Citizenship, Princeton: Princeton University Press

Bowman, Paul (2007): Post-Marxism versus Cultural Studies: Theory, Politics and Intervention, Edinburgh :Edinburgh University Press

----- (2011): Studi culturali: Teoria, intervento, cultura pop, a cura di Floriana Bernardi, Bari: Progedit

Braudel, Fernand (1977): Afterthoughts on Material Civilization and Capitalism, The Johns Hopkins Symposia in Comparative History, Baltimore, Johns Hopkins University Press.

------ (1995), A History of Civilizations, translated by Richard Mayne, New York: Penguin Books

Cotgrove, Stephen \& Andrew Duff (1980): "Environmentalism, Middle-Class Radicalism and Politics", Sociological Review, 28:2, 333-352.

De Blasio, Emiliana \& Michele Sorice (2007): "Cultural Studies in Italy and the Influence of Gramsci, Catholic Culture and the Birmingham School (CCCS)", Cultural Studies Now - Conference Journal 2007, Centre for Cultural Studies Research, University of East London.

Đilas, Milovan (1957): The New Class: An Analysis of the Communist System, San Diego: Harcourt Brace Jovanovich.

Fumaroli, Marc (1991): L'État culturel. Essai sur une religion moderne, Paris: Éditions de Fallois. Grossberg, Lawrence (1988): "Wandering Audiences, Nomadic Critics", Cultural Studies, 2:3, 377-391. 
Grossberg, Lawrence (2006): "Does cultural studies have a future? Should it? (Or what's the matter with New York?)/Cultural studies, contexts and conjunctures", Cultural Studies, 20:1, 1-32.

Grossberg, Lawrence (2010): Cultural Studies in the Future Tense, Durham: Duke University Press.

Harris, David (1992): From Class Struggle to the Politics of Pleasure: The Effects of Gramscianism on Cultural Studies, London-New York: Routledge

Holub, Renate (2001): "Post-War Italian Intellectual Culture: From Marxism to Cultural Studies", Christa Knellwolf \& Christopher Norris (eds): The Cambridge History of Literary Criticism, Volume 9: Twentieth-Century Historical, Philosophical and Psychological Perspectives, Cambridge: Cambridge University Press

Hutnyk, John (2004): Bad Marxism: Capitalism and Cultural Studies, London-Ann Arbor: Pluto Press

de Landa, Manuel (1997): A Thousand Years of Non-linear History, New York: Zone Books.

Mezzadra, Sandro (2011): "Bringing Capital Back in: A Materialist Turn in Postcolonial Studies?", Inter-Asia Cultural Studies, 12:1, 154-164.

Mouffe, Chantal (2000): Deliberative Democracy or Agonistic Pluralism, Wien: Institut für Höhere Studien

Pužar, Aljoša (2007): "Whispering so Radically: Croatian Cultural Studies and Liminal University”, Cultural Studies Now - Conference Journal 2007, Centre for Cultural Studies Research, University of East London.

Pužar, Aljoša (2010): "Piratical Cultural Studies: Transgressive Individualism Reconsidered, Cultural Studies <=> Critical Methodologies, 10:3, 187-98.

Pužar, Aljoša (forthcoming): "Cultural Studies and/on Borders: Complexity and Transgression", Eduardo de Gregorio-Godeo \& Ángel Mateos-Aparicio (eds): Mapping Identities and Identification Processes: Approaches from Cultural Studies, New York: Peter Lang.

Szakolczai, Arpad (2001): "In a Permanent State of Transition: Theorising the East European Condition", Limen 1 (2001).

Todorov, Tzvetan (2005): New World Disorder: Reflections of a European, preface by Stanley Hoffmann; translated by Andrew Brown, Cambridge: Polity Press. 